\title{
Chapter 3: \\ The Proliferation of Āsana-s in Late-Medieval Yoga Texts ${ }^{*}$
}

\section{Introduction}

Some scholars have already noted that the number of postures (āsana) described in the better-known Sanskrit yoga texts is considerably smaller than the large number of $\bar{a}$ sana-s practised in twentieth-century yoga. ${ }^{1}$ Relatively few āsana-s are mentioned in the Pātañjalayogaśāstra, its main commentaries and the three Hatha Yoga texts which were widely published in the twentieth century, namely, the Śivasam hitā (ŚS), the Hathapradīpikā (HP) and the Gherandasam hitā (GS). Among these, the Gherandasamhitā teaches the most āsana-s, namely, thirtytwo. On the basis of these sources, medieval yoga ${ }^{2}$ appears to have little to do with

* The findings of this paper were first made public in the conference "Yoga in Transformation: Historical and Contemporary Perspectives on a Global Phenomenon" at the University of Vienna, 19-21 September 2013. Since then, my work on this paper has received funding from the European Research Council (ERC) under the European Union's Horizon 2020 research and innovation programme (grant agreement No. 647963). I wish to thank Jacqueline Hargreaves for her many suggestions and for proof-reading several drafts of this chapter. Thanks also to Mark Singleton, Beatrix Hauser and Seth Powell for their comments on an earlier draft and, in particular, to Philipp Maas and James Mallinson for their numerous comments and generous advice on specific matters. I am grateful to both Mallinson and Singleton for their help in transcribing, translating and suggesting emendations on the passages on àsana practice in Appendices 1 and 2. I am also grateful to Christina Ong and Fiona Tan of COMO Shambhala, Singapore, for providing me with periods of paid work, which has financed the preliminary research for this chapter, and the ERC-funded Hatha Yoga Project for funding the work that has enabled me to complete this chapter.

1 For example, Dasgupta 1969: 205, Sjoman 1999: 39-40, Bühnemann 2007a: 20-21, Larson 2008: 148, Singleton 2010: 32-33, etc.

2 My periodisation of yoga's history is based on changes in its development. I take the beginning of the mediaeval period as the fifth or sixth century CE, which is the date of the earliest textual evidence for Tantric and Paurānic systems of yoga. I have extended the medieval period to the eighteenth century because the influence of modernity on yoga texts is evident only after this time. My designation of a late medieval period of the sixteenth to eighteenth century is based on distinct differences between the early corpus of Hatha and Rāja Yoga, which culminated in the Hathapradīpika (15th c.), and the yoga texts written after the fifteenth century, which tend to be more scholarly productions that either expound upon Hațha and Rāja Yoga in greater 
the proliferation of $\bar{a} s a n a-s$ in yoga texts written in the early twentieth century. ${ }^{3}$ However, the lack of historical evidence on the practice of $\bar{a}$ sana-s has hampered scholarly efforts to reconstruct the modern history of yoga, as Joseph Alter has stated: ${ }^{4}$

[...] there is virtually nothing that allows for the construction of a history of āsana practice. Clearly this signals the need for ongoing research. [...] the paucity of any clear history of practice in the eighteenth and nineteenth centuries should raise a red flag of sorts concerning the putative antiquity of everything that is now counted as Hatha Yoga.

The writing of this chapter was prompted by the discovery of several manuscripts of medieval yoga texts which contain lists of more than eighty-four àsana-s, a canonical number mentioned in several yoga texts. ${ }^{5}$ Until now, lists of eighty-four $\bar{a}$ sana-s have been found in only two recently published yoga texts, namely, the Hatharatnāvalī (HR) and the Jogapradīpyak $\bar{a}$ (JP). ${ }^{6}$ The manuscript evidence presented in this chapter indicates that these published texts are not isolated accounts of medieval yoga systems with many complex āsana-s. In fact, it is clear that more than eighty-four āsana-s were practised in some traditions of Hatha Yoga before the British arrived in India. The majority of these āsana-s were not seated poses, but complex and physically-demanding postures, some of which involved repetitive movement, breath control and the use of ropes. When the $\bar{a}$ sana-s in the sources which I shall analyse in this chapter are considered in their totality, antecedents can be identified for many non-seated ${ }^{7}$ and inverted postures in twentieth-century systems of Indian yoga.

When the above late-medieval yoga texts are taken into account within the broader history of Hatha Yoga, ${ }^{8}$ it becomes apparent that there was a substantial increase in the number of āsana-s after the sixteenth century and that, from the seventeenth century onwards, various lists of eighty-four or more àsana-s have been recorded. In contrast to this, very few äsana-s were mentioned or described

detail or attempt to synthesise teachings of Hatha and Rāja Yoga with those of Brahmanical texts (including Pātañjalayoga).

3 One of the most extensive surveys of Indian äsana-s from both modern and pre-modern sources is Gharote et al. 2006.

4 Alter 2004: 23.

5 Bühnemann 2007a: 25-27.

6 Other yoga texts such as the Yogāsanamālā are mentioned in Gharote et al. 2006: lxxii and Kaivalyadhama Yoga Institute 2006: 13, but these texts have not yet been published.

7 Non-seated postures usually refer to those âsana-s performed in a standing, supine, prone, twisting, back-bending, forward-bending or arm-balancing position. The one exception to my comment above is that medieval yoga traditions provide very few antecedents to modern standing poses. See the Conclusion and Appendix 3 of the present chapter for more information on this.

8 For a chronology of published Hatha texts, see Birch 2011: 528-529. The relevant unpublished material is described and dated in this paper. 
in the early Hatha texts, which can be dated from the twelfth to fifteenth centuries.

The present chapter consists of six sections. Following this Introduction, Section 2 is a general overview of the historical development of $\bar{a} s a n a$ in Hatha Yoga. This should provide some context for the examination of three manuscripts in Section 3, which leads to questions concerning the chronology and increments of the number of äsana-s in medieval yoga discussed in Section 4. Section 5 investigates the relationship between medieval and modern àsana practices. There, I shall propose reasons for why these extensive lists of āsana-s occur only in sources which were written after the sixteenth century and I shall discuss whether these àsana-s influenced those gurus who led the revival of physical yoga in the twentieth century. Finally, Section 6 provides a summary of the main results of the present chapter as well as the prospects for future research.

\section{The History of Āsana in Hațha Yoga}

In the fifteenth century, Svātmārāma compiled the Hathapradīpikā by borrowing verses from various medieval yoga texts, which taught either a system of Hatha and Rāja Yoga or techniques that were incorporated into later traditions of Hatha Yoga. Most of these earlier texts mention or describe only one or two āsana-s. In most cases, these are seated āsana-s such as the lotus pose (padmāsana). The names of these āsana-s are found in the Pātañjalayogaśāstra, except for siddhāsana, which may have been known to Patañjali by a different name. ${ }^{9}$ The following table summarises the number of āsana-s in early Hatha texts: ${ }^{10}$

9 The Pātañjalayogaśāstra contains the names of thirteen āsana-s but it does not describe them. Therefore, the postural shape of these āsana-s at the time of Patañjali is uncertain. The earliest descriptions of them are found in Śankara's commentary on the Pātañjalayogaśāstra (see Maas' chapter in the present volume, p. 62) and none of these descriptions mention the penis being pressed by either one or both heels. Siddhāsana is referred to by other names in medieval yoga texts, such as the Gorakșaśataka (15), which calls it vajrāsana. The Hațapradīpikā states that it was also known as muktāsana and guptāsana. As Philipp Maas has kindly pointed out to me (personal communication, 3 October 2013), the Pãtañjalayogaśāstra's list of thirteen àsana-s is not definitive because it ends with ityevamādi (i.e., "and so forth"). Nonetheless, there was no proliferation of àsana-s in the commentarial tradition of Pātañjalayoga, until the late medieval period when the seventeenth-century Nārāyanatīrtha listed and described thirty-eight āsana-s in his commentary the Yogasiddhāntacandrikā on sūtra 2.46. Most of these àsana-s are borrowed from earlier yoga texts, most notably the Hațhapradīpikā (which Nārāyanatīirtha refers to as the Yogapradīpa), the Vasișthasamhitā and the Dharmaputrikā (for more information on the Yogasiddhāntacandrikā, see Birch 2013b: 414-415).

10 The Yogatärävalì's terminus a quo is the composition of the second chapter of the Amanaska 


\begin{tabular}{|l|l|l|l|l|}
\hline Text & $\begin{array}{l}\text { Probable date } \\
\text { CE }\end{array}$ & $\begin{array}{l}\text { No. of āsana-s } \\
\text { named but not } \\
\text { described }\end{array}$ & $\begin{array}{l}\text { No. of äsana-s } \\
\text { named and } \\
\text { described }\end{array}$ & Total \\
\hline Amaraughaprabodha & 14 th c. & 0 & 0 & 0 \\
\hline Amṛtasiddhi & 12 th c. & 0 & 0 & 0 \\
\hline Khecarīvidyā & 14 th c. & 0 & 0 & 0 \\
\hline Yogatārāvalī & 14 th c. & 0 & 0 & 0 \\
\hline Yogabīja & 14 th c. & 1 & 0 & 1 \\
\hline Dattātreyayogaśāstra & 13 th c. & 1 & 1 & 2 \\
\hline Gorakșaśataka & $12-13$ th c. & 0 & 2 & 2 \\
\hline $\begin{array}{l}\text { Vivekamārtaṇḍa } \\
\text { (Viv) }\end{array}$ & $12-13$ th c. & 0 & 2 & 2 \\
\hline Śivasaṃhitā & 15 th c. & 2 & 4 & 6 \\
\hline Yogayājñavalkya & 14 th c. & 0 & 8 & 8 \\
\hline Vasiș̣thasaṃhitā & 12 th c. & 0 & 10 & 10 \\
\hline
\end{tabular}

Table 1: The number of àsana-s in early Hatha texts.

Three of the above texts teach non-seated āsana-s, namely, the Vasisthasamhitā, the Yogayājñavalkya and the Sivasamhitā. The twelfth or thirteenth-century Vasisthasamhitā is the earliest extant textual source on Hatha Yoga to include non-seated postures, which are mayūrāsana and kukkutāsana. ${ }^{11}$ Eight of the āsana-s in the Vasiṣthasaṃhitā, including mayūrāsana but not kukkuțāsana, were reproduced in the Yogayājñavalkya, which was probably written a century or two later and borrows extensively from the Vasișthasamhitā. ${ }^{12}$ The fifteenth-

(11th-12th CE), on the basis of one parallel verse and the more general influence of the Amanaska's Rāja Yoga (Amanaska $2.67 \approx$ YTĀ 20 ; for my arguments on why this text would not predate the Amanaska, see Birch 2011:528, n. 19). The Yogatārāvalī's terminus ad quem is

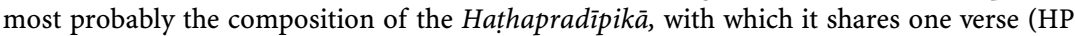
$4.66 \approx \mathrm{YTA} \overline{\mathrm{A}} 2$ ), as well as the seamless combination of Hațha and Rāja Yoga, which probably post-dates the hierarchy of four yogas (i. e., Mantra, Laya, Hațha and Rāja). For a discussion of the date of the Śivasamhitā, see n. 13.

11 The Aștānngayoga of Vasiṣtha and Yājñavalkya is taught in these two texts. Their Aștângayoga is referred to as one of two types of Hațha Yoga in DYŚ 26c-29: "That [described in the previous section] was Laya Yoga. Now listen to Hatha Yoga. General observances, preliminary practices and, after that, postures, breath control is the fourth [auxiliary], sense withdrawal the fifth, then concentration is taught, meditaton is said to be the seventh and absorption, which bestows the rewards of all merit, is the eighth. Yãjñavalkya and others know Aṣțāngayoga thus. Siddhas, such as Kapila and so on, practise a Hatha Yoga different to that" (sa eva layayogah syād dhațayogam tatah śṛnu || 26 || yamaś ca niyamaś caiva āsanam ca tatah param | prānāyāmaś caturthah syāt pratyāhāras tu pañcamah || 27 || tatas tu dhāranāa proktā dhyānam saptamam ucyate | samädhir aștamah proktah sarvapunyaphalapradah || 28 || evam aṣtāngayogam ca yājñavalkyādayo viduh| kapilādyās tu siddhāś ca hațam kuryus tato 'nyathā).

12 For the relevant references on dating the Vasișthasamhitā and the Yogayājñavalkya, see Birch 2011: 528. 
century Śivasaṃitā (3.109) teaches paścimottānāsana, a forward bending posture, and extols it as one of the foremost (agrya) āsana-s. ${ }^{13}$ Nonetheless, these sources do not suggest that an early tradition of Hatha Yoga incorporated the practice of numerous àsana-s. In fact, the emphasis of these texts is on prāṇāyāma and mudrā and, in most cases, only those āsana-s required for such practices were considered important.

Although the aforementioned texts of Hatha Yoga's early traditions teach relatively few āsana-s, it would be a mistake to conclude that these were the only àsana-s known to their authors. Several of the early texts acknowledge the existence of eight million four hundred thousand āsana-s (caturaśítilakṣa) and assert that Siva taught eighty-four of them. For example, the Dattätreyayogaśāstra, one of the earliest extant yoga texts to teach Hatha Yoga (Mallinson 2011: 771), says:

Among the eight million four hundred thousand āsana-s, listen to [my description of] the best one. In this system it is called lotus pose, [which] was taught by Siva. ${ }^{14}$

A statement similar to the above is found in the Vivekamārtanda (8-10), a yoga text that may have been written close to the time of the Dattātreyayogaśāstra. ${ }^{15} \mathrm{It}$ does not mention Hatha Yoga by name, but was one of the sources of the Hațapradīpikā (Mallinson 2014: 239):

There are as many āsana-s as there are types of living beings. Siva knows all the varieties of them. Every one of the eight million four hundred thousand āsana-s has been named by Śiva and, from among them, he taught eighty-four postures. From the aggregate of

13 The ŚS (3.108-109) may predate the Hathapradipikā because the latter contains several verses of the former (see Mallinson 2014: 239-244). However, whether every chapter of the Śivasaṃhitā predates the Hațhapradīpikā is, in my opinion, uncertain because the Śivasaminitā does not appear to be a cohesive text. The fifth chapter may have been written separately from the first four chapters because it contains some teachings that contradict statements in the earlier chapters. For example, in the third chapter (3.40-41), a list of twenty niyama-s is given. However, at 5.7, niyama is listed among the obstacles to yoga. Also, there are different lists of obstacles in the third and fifth chapters, and the fifth chapter teaches a tetrad of yogas (i.e., Mantra, Laya, Hațha and Rāja), which is not mentioned as such in the earlier chapters. The dating of the Śivasamhitā is further complicated by the fact that it is a compilation containing verses of the Dattātreyayogaśāstra and the Amrtasiddhi (Mallinson 2007b: x). Therefore, the Hațhapradīpikā and the Śivasaṃhitā may have borrowed from a third source that is no longer extant. The composition of the Yuktabhavadeva, which contains a colophonic verse with the date $1623 \mathrm{CE}$, remains the most certain terminus ad quem of the Śivasamhitā in its current form because the Yuktabhavadeva (7.261-285) quotes with attribution passages from the third, fourth and fifth chapters of the Sivasamhitā.

14 DYŚ 34: caturasítilakṣeșu āsaneșūttamam śrṇu | ādināthena samproktam padmāsanam ihocyate $\|$.

15 Similar statements on eighty-four āsana-s also occur in the Sivasamhitā (3.96) and the Hațhapradīpikā (1.35). 
$\bar{a}$ sana-s, only these two are important; the first is called siddhāsana and the second kamalāsana. ${ }^{16}$

While such statements are partly rhetorical devices that assert the divine origin of all āsana-s, much like the so-called saastric paradigm in various genres of Sanskrit literature, ${ }^{17}$ the recognition of innumerable āsana-s in a culture accustomed to sitting on the ground should come as no surprise. Also, it is possible that many äsana-s were practised before the fifteenth century by other ascetic and martial traditions which have left no written record. References to assana practice in the Mallapurāṇa, a late medieval text on wrestling, and Kāmaśástra texts have been noted by Norman Sjoman ${ }^{18}$ and Gudrun Bühnemann, respectively. ${ }^{19}$ When one considers that the early traditions of Hatha Yoga taught only a handful of āsana-s but were aware of many more, it suggests that these traditions dismissed the practice of many different āsana-s in favour of only those that facilitated other techniques, namely, prānāyāma and mudrā.

Christian Bouy ${ }^{20}$ and Mallinson ${ }^{21}$ have shown that the Hathapradīpika is largely an anthology of earlier Hațha and Rāja Yoga texts. By surreptitiously

16 Vivekamārtanḍa 8-10: āsanāni ca tāvanti yāvatyo jīvajātayah | eteșām akhilān bhedān vijānāti maheśsarah || 8 || caturāsítilakșānām ekaikam samudāhṛtam| tatah śivena pīthānām şodaśonam śatam krtam || 9 || āsanebhyah samastebhyo dvayam eva viśisyate | ekam siddhāsanaṃ proktaṃ dvitīyaṃ kamalāsanam \| $10 \|$. 8a ca] Viv, VivB, VivN1, Gś: tu Gśk. 8a-b tāvanti yāvatyo] Viv : tāvanti yā vato VivN2 : tāvanti yāvantyo Gś, Gśl : tāvanti yāvanto VivB : tāvanto yā vanto VivN1. 8b jīvajātayah ] Viv, VivB, Gś, Gśk : jīvajantavah VivN1, VivN2. 8c akhilān bhedān] Viv, VivB, Gś, Gśk, akhilāb bhedān VivN2 : tulā bhedā yo VivN1. 9b ekaikam samudāhṛtam] VivB, VivN2, Gś : caikaikaṃ samudrāhṛtam VivN1 : ekaṃ ekam udāhṛtam Viv, Gśk. 9c pīthānām ] $\sum$ : pìthena VivN1. 9d șodaśonam ] $\sum$ : șodaśānām VivN1. 10b eva viśisyate] VivN1, Gśk: eva praśasyate Viv : etad udāhṛtam VivB, VivN2, Gś. 10c proktam ] Viv, VivB, VivN1, VivN2, Gśk : tatra Gś. For the abbreviations (e.g., Viv, VivB, etc.) in the apparatus, please see the list of abbreviations at the end of this chapter.

17 See Pollock 1985: 512 for his discussion of the saasstric paradigm. McComas Taylor (2007: 69) has defined it succinctly as follows: "This paradigm incorporates a set of common features, including claims of cosmogonic origins, divine authorship, and vast scope, which serve to empower and valorize śāstric texts."

18 Sjoman 1999: 56-57.

19 Bühnemann (2007a: 27, n. 62, 2007b: 158) cites a modern work called the Sañkhyāsañketakośa by Hanmmamte, who lists eighty-four positions from the Kokaśāstra. However, my research on the Kokaśástra, a Sanskrit text otherwise known as the Ratirahasya (Upadhyaya 1965) and generally ascribed to the twelfth century, has failed to confirm this. Chapter ten of the Kokaśästra is on sexual positions (bandha), and it describes thirty-eight positions and mentions the names of another four. I was unable to find any mention of eighty-four positions in this work. Some manuscript catalogues indicate that there is a Persian translation of the Kokaśāstra, dated 1763-1764 and called Khulāsat al-'aish-i 'Ālam Shāhī, a Braj Bhāsāā translation called the Kokamañjarī, one manuscript of which is dated $1784 \mathrm{CE}$, and a Marathi one called the Ratimañjarī. I am yet to consult any of these eighteenth-century works, but it is possible that Hanmaṇte took his list of āsana-s from one of them.

20 Bouy 1994.

21 Mallinson 2011: 772-773 and 2014: 239-244. 
integrating a variety of sources, Svātmārāma described more postures in the Hathapradīpika than did the earlier yoga texts, and he states that he knew more than the fifteen poses in his work:

[Only] some of the äsana-s accepted by sages such as Vasistha and yogis such as Matsyendra are mentioned [in this text] by me. ${ }^{22}$

The reference to Vasiștha points to the àsana-s of the Vasisthasamhitā, eight of which are reproduced verbatim in the Hathapradipik $\bar{a}{ }^{23}$ However, the exact nature of Matsyendra's association with Hatha Yoga remains unclear because there is no earlier, extant Hatha text attributed to him, and no earlier source for the pose called matsyendrāsana. Therefore, there is not enough textual evidence to determine how many postures Svātmārāma may have known beyond the fifteen he recorded in the Hathapradipikā.

After the time of the Hathapradīpikā, a list of names of eighty-four āsana-s, thirty-six of which are described, was recorded in the Hatharatnāvalī, which was probably written in the seventeenth century. ${ }^{24}$ There are descriptions of eightyfour postures in the Jogapradipyaka and one hundred and ten in the Yogāsanamāla ${ }^{25}$ Both of these texts can be dated to the eighteenth century on the basis of the oldest scribal dates in manuscripts of these texts (Kaivalyadhama Yoga Institute 2006: 11-13). The Hațaratnāvali and the Jogapradīpyakā have been published in India but are not widely available, though Bühnemann ${ }^{26}$ has discussed them in her work on eighty-four āsana-s.

The three manuscripts that are the focus of this chapter, the Yogacintamani (YC) (Ujjain ms.), the Hathapradīpikā-Siddhāntamuktāvalī (SMĀ) and the Hațhäbhyāsapaddhati (HAP), corroborate the chronological increase in the number of àsana-s seen in published texts. The proliferation of āsana-s is shown in the following table: ${ }^{27}$

22 HP 1.18: vasișthādyaiś ca munibhir matsyendrādyaiś ca yogibhih | añgīkrtāny āsanāni kathyante kāni cin mayā $\|$.

23 These verses are identified in Mallinson 2014: 240.

24 Śrīnivāsabhața's Hatharatnāvalì's terminus a quo is the composition of the fifteenth-century Hațhapradīpika , which is mentioned by name in the Hațharatnāvali at $1.12,27-28,50,2.87$, 141 and 3.23. The Hatharatnāvalìs terminus ad quem is the composition of the Hathatattvakaumudī of the eighteenth-century Sundaradeva who quotes the Hatharatnāvalì with attribution at 8.3 and 13 .

25 I have consulted one manuscript of the Yogāsanamālā (ms. no. 5450 Rajasthan Oriental Research Library, Jodhpur), which numbers its āsana-s up to one hundred and ten. However, folios 18, 24, 25, 26 and 27 are missing. Therefore, only one hundred and five āsana-s remain in this manuscript. All of these āsana-s have names and illustrations, and most of them are described.

26 Bühnemann 2007a: 27-29, 2007b: 159-160.

27 The numbers presented for the Jogapradīpyakā require specification: At JP v. 498, which is in the chapter on prānāyāma, gorakha äsana is mentioned but not described. In the third 


\begin{tabular}{|c|c|c|c|c|}
\hline Text & $\begin{array}{l}\text { Probable } \\
\text { date CE }\end{array}$ & $\begin{array}{l}\text { No. of äsana-s named } \\
\text { but not described }\end{array}$ & $\begin{array}{l}\text { No. of āsana-s } \\
\text { named and de- } \\
\text { scribed }\end{array}$ & Total \\
\hline Haṭhapradīpikā & 15 th $\mathrm{c}$. & 0 & 15 & 15 \\
\hline Yogacintāmaṇi & 17 th $\mathrm{c}$. & 0 & 34 & 34 \\
\hline $\begin{array}{l}\text { Yogacintāmanịi } \\
\text { (Ujjain ms.) }\end{array}$ & 1659 & 56 & 62 & 118 \\
\hline Haṭharatnāvalī & 17th c. & 48 & 36 & 84 \\
\hline Gherạ̣ḍasaṃhitā & 18th c. & 0 & 32 & 32 \\
\hline $\begin{array}{l}\text { Hațhapradīpikā-Sid- } \\
\text { dhāntamuktāvalī }\end{array}$ & 18th c. & 0 & 96 & 96 \\
\hline Jogapradīpyakā & 18th c. & 1 & 89 & 90 \\
\hline Yogāsanamālā & 18th c. & 0 & 110 & 110 \\
\hline Haṭhābhyāsapaddhati & 18th c. & 0 & 112 & 112 \\
\hline
\end{tabular}

Table 2: The proliferation of àsana-s.

Most of the texts listed in the above table repeat the statement that Siva taught eighty-four āsana-s, which first occurs in the Dattātreyayogaśāstra and the Vivekamārtanda. ${ }^{28}$ The significant difference is that they tend to add to this statement either lists of names or descriptions of eighty-four or more āsana-s.

\section{Three Unpublished Manuscripts}

\subsection{The Ujjain Manuscript of the Yogacintāmaṇi}

Two centuries after the Hathapradīpikā, several large yoga compilations which integrated teachings of Haṭha and Rāja Yoga with those of Pātañjalayoga and Brahmanical texts were written. One such work is the early seventeenth-century Yogacintāmaṇi of Śivānandasarasvatī, an Advaitavedāntin who probably resided in Vārāṇasī during the reigns of the Moghul rulers Shāh Jahān and his sons. ${ }^{29}$ The

chapter of the Jogapradipyakā, eighty-four āsana-s are described, but another four are described at various places in the chapter on prānāyāma (Kaivalyadhama Yoga Institute 2006: 73). Therefore, the Jogapradīpyakā contains just a single āsana that is mentioned but not described, whereas the total number of described āsana-s is 89 .

28 The Yogacintāmañi (p. 157) quotes Viv 8cd-10 as Gorakṣa and HP 1.35 with attribution; HR 1.18, 3.7-8, 23; GS 2.1; SMĀ fol. 25v, 1l. 4-5 (verse no. 2.31); JP vv. 360-361.

29 On the date of the Yogacintāmaṇi, see Birch 2013b: 421, n. 7. The hypothesis that Śivānanda was a resident of Vārānasī is supported by his reference to his devotion to Viśveśvara, a standard claim of Śaivas who resided there. I wish to thank Alexis Sanderson for pointing this out to me. Moreover, he also noted that similar references to Viśveśvara in works of Śaivas who resided in Vārānasī can be found in Jñānaśiva's Jñānaratnāvalī and Viśvanātha's Siddhāntaśekhara, which are both Saiddhāntika Paddhatis (personal communication, 24 April 
latter half of this work is structured according to the standard eight auxiliaries of yoga. In the section on āsana, there are descriptions of thirty-four āsana-s from a wide selection of sources, ${ }^{30}$ including the Pātañjalayogaśāstra, Vācaspatimiśra's commentary thereon, Bhojadeva's Rājamārtaṇda, several Purānas - the Āgneya, Kürma and Skandapurāna, two Tantric Śaiva works - the Matañgapārameśvara and Dharmaputrikā - and six medieval yoga texts - the Dattātreyayogaśāstra, the Vivekamārtanda, the Vasisthasamhitā, the Yogayājnavalkya, the Hathapradīpikā and an unknown text called the Pavanayogasangraha. ${ }^{31}$ Sivānanda cited the names of all his sources, which makes the Yogacintāmani a valuable resource for dating some yoga texts and for identifying others that are no longer extant.

Among the five manuscripts and one printed edition of the Yogacintāmani that have been consulted for this chapter, one manuscript contains considerably more àsana-s than the others. The manuscript in question, which I refer to as the "Ujjain manuscript", is held at the Scindia Oriental Research Library in Ujjain. Its final colophon is the same as that of other manuscripts of the Yogacintamani. ${ }^{32}$ After the final colophon, the scribe has written the date "1717 jyeșthe śuddha 15 brhaspatyām ${ }^{33}$ pürnah". ${ }^{34}$

Unfortunately, the era (i.e., vikrama or śaka) is not specified. However, the details concerning the bright half (śuddha) of the month named Jyaistha, the fifteenth tithi and the day, Thursday (brhaspati), confirm that the year was vikramasamvat 1717 (i.e., Thursday, 5 June 1659 CE), as long as one understands the 1717 as a current northern year, and not an expired one. ${ }^{35}$ Therefore, this manuscript was written in the mid-seventeenth century. Some changes have been made to the numbers of folios and at least four folios have been added to the section on $\bar{a}$ sana. ${ }^{36}$ However, the scribe's hand is consistent throughout the

2013). The reference to Śivānanda being a devotee of Viśveśvara occurs in a colophonic verse, which may have been written by Śivānanda himself, in ms. 6922, last folio, 11. 6-10 and ms. 9784 pp. 189-190.

30 The number thirty-four is achieved by counting different versions of the same pose separately.

31 For the list of the texts cited in the Yogacintämani, see Gode 1953: 472-473.

32 YC, ms. no. 3537, fol. 104v, 1l. 7-8: iti śrīmatparamahaṃsaparivrājakācāryaśrīrāmacandrasadānandasarasvatīśsyaśivānandasarasvatīviracitayogacintāmaṇau caturthah paricchedah samāptaś cāyaṃ grantho 'pi $\|$ rudrasūno[r] bālyagastino gargho 1 nāmn[o] 'yam granthas tenaiva likhitah [ll] .

33 Emend. brhaspatyām : Codex brhaspatyam.

34 YC, ms. no. 3537, fol. 104v, 1. 8. Part of the date is in the left margin.

35 I wish to thank Philipp Maas for pointing out to me that the calculation of 1717 as a current northern year yields the right day (i. e., Thursday). The calculation of 1717 as an expired year in the vikrama era gives Wednesday and in the śaka era, Tuesday. Also, taking 1717 as a current year in the śaka era gives the wrong day (i.e., Friday). I have tested these calculations using both the Amānta and Pūrnimānta schemes.

36 The changes made to the folio numbers begin at folio 43 , which is well before the section on assana. I can see no reason for the change at folio 43 , other than, perhaps, to correct an error in 
manuscript, so the date of its additional lists of āsana-s must be close to that of the manuscript. This means that it was probably written around the same time as the Hatharatnāvalī. Seeing that the earliest date for a catalogued manuscript of the Hațaratnāvali is $1812 \mathrm{CE},{ }^{37}$ the Ujjain manuscript of the Yogacintāmaṇi is the earliest dated manuscript containing lists of more than eighty-four names of àsana-s.

The section on āsana in the Ujjain manuscript begins with the same introductory remarks as those in other manuscripts of the Yogacintāmani. However, there is one small but significant variation in the opening comment, which reads: ${ }^{38}$

athāsanāni 84 tatra patañjaliḥ || sthirasukham āsanam \|

Now, the 84 āsana-s. On this [subject], Patañjali [said], "An àsana is steady and comfortable".

Other manuscripts do not mention the number eighty-four, but simply have athāsanam. The scribe of the Ujjain manuscript inserted the " 84 " with the intention of describing more than the thirty-four āsana-s that are usually found in the Yogacintāmaṇi.

Another significant difference between the Ujjain manuscript and other manuscripts of the Yogacintamani is that the scribe listed and numbered the àsana-s rather than just copying them as text. The number and the name of each pose are written on the left side of each folio and the description on the right side. ${ }^{39}$ The change in format indicates that the scribe was compiling a list of $\bar{a}$ sana-s that went beyond the text of the Yogacintamani. After the thirty-fourth

the original numbering. Some of the changes were made by writing over the original numbers, but most by covering the original numbers with a yellow paste. The section on āsana begins on folio 58v, and the changes that have been made to folios 58-62 appear consistent with the changes made to the previous folios. However, the numbers of folios 63-66 have not been corrected, which indicates that these folios were probably added at a later time. These inserted folios contain most of the third list of āsana-s. The two folios following this inserted section have the same numbers as the previous two folios (i.e., 65-66) and, in this chapter, I refer to them as folios $65 \mathrm{a}$ and $66 \mathrm{a}$. The verso side of the folio at the end of the section on $\bar{a}$ sana (i.e., $67 \mathrm{v}$ ) has verses on yoga, which are not found in other manuscripts of the Yogacintämani. I have traced these verses to a chapter on yoga in the Śärngarapaddhati (4508-4516). On the next folio (i.e., 68), the second chapter of the Yogacintāmaṇi begins.

37 HR, reel No. A 990-19 (1), Kathmandu National Archives. See http://catalogue.ngmcp.unihamburg.de/wiki/A_990-19(1)_Hațharatnāvalī (accessed 12 August 2014). The earliest dated manuscript used by M. L. Gharote (2009: xiii) for his critical edition of the Hatharatnāvali is ms. no. 4-39, dated saṃvat 1895, mārgasiîrṣa śukla pañcamī bṛhaspativāre (Thursday, 22 November 1838).

38 YC, ms. no. 3537, fol. 58v, 1. 4.

39 There are actually two sets of numbers. The one on the right side of the name of each pose appears to be the original numbering because it excludes several äsana-s which were added in the margins and as interlinear comments at a later time. 
$\bar{a}$ sana ${ }^{40}$ the scribe has inserted the colophon "iti yogacintāmaṇāv āsanasangrahah". ${ }^{41}$

This colophon marks the end of the collection of āsana-s as they appear in the other manuscripts of the Yogacintamani. An obscure scribal comment after the colophon seems to indicate that five $\bar{a}$ sana-s were added to this collection, ${ }^{42}$ but the most important feature of the Ujjain manuscript is that its list of āsana-s continues beyond the colophon to add another twenty-one āsana-s, which are numbered thirty-five to fifty-four. Six of these additional āsana-s have the same names as āsana-s mentioned in the bhāsya part of the Pātañjalayogaśāstra (2.46) and, apart from one exception, their descriptions derive from Vācaspatimiśra's Tattvavaiśa $\overline{r a d} \bar{\imath}_{.}^{43}$ However, as far as I am aware, the remaining fifteen descriptions are not found in any yoga text that predates the sixteenth century. ${ }^{44}$

After the àsana numbered forty-nine, a table has been inserted at the bottom of folio $62 \mathrm{v}$, as can be seen in Figure 1. It contains the names of eighty-one $\bar{a}$ sana-s in alphabetical order. Seeing that thirty-nine of these āsana-s are not found in the list above it, the contents of the table can be seen as a second, separate list. It is possible that the scribe intended to insert eighty-four āsana-s in the table but was prevented from doing so because of congestion within some of the cells, in particular, $k a$ and $s a$.

On the folio following the table (i.e., 63r) begins an unnumbered list of one hundred and twelve names of $\bar{a}$ sana-s, which includes seventeen repetitions. This is a third separate list, in which the names of the àsana-s are placed vertically

40 This is numbered thirty-three on the left side of the name of the pose. The discrepancy in the numbering arises from the fact that the scribe has included two different types of padmāsana under one heading.

41 YC, ms. no. 3537, fol. 61v, 1. 5.

42 The scribal comment after iti yogacintāmanā $v$ āsanasangrahah is difficult to decipher but reads: yatra puro 'nkkah (29) sah añkātiriktam (7) anyatah sañgrhìtam paścād añkaih || (note: the śca of paścād is not clear). This comment, which has been corrected at another time, seems to be pointing out that the group of twenty-nine āsana-s (according to the manuscript's numbering on the left of each āsana's name) above this colophon is from the Yogacintāmani, whereas seven àsana-s were added from elsewhere. In actual fact, seven àsana-s have been added as marginal notes and interlinear comments to those usually found in the Yogacintāmaṇi. These are kevalasvastika, ardha, garuḍa, markața, garbhāsana, paryainka and viräsana. Therefore, the scribal comment following the colophon is probably referring to those seven additional āsana-s which have been numbered. I wish to thank Péter-Dániel Szántó, Somdeva Vasudeva, Csaba Kiss, James Mallinson and Mark Singleton for their help in deciphering this comment.

43 These āsana-s are danḍ̄sana, sopāśraya, krauñcanișadana, hastinaḥ (= hastinișadana), uștrasya (= ustranișadana) and samasthāna. The descriptions of dạda, sopāśraya and samasthāna are almost the same as those by Vācaspatimiśra, and the description of sopāśraya is followed by iti vācaspati. The descriptions of krauñca and hastinisadana do not vary much from earlier ones. However, the description of uștranișadana may be unique (see Appendix 1).

44 These āsana-s are numbered 35, 38, 43-55 in Table 3, below. 


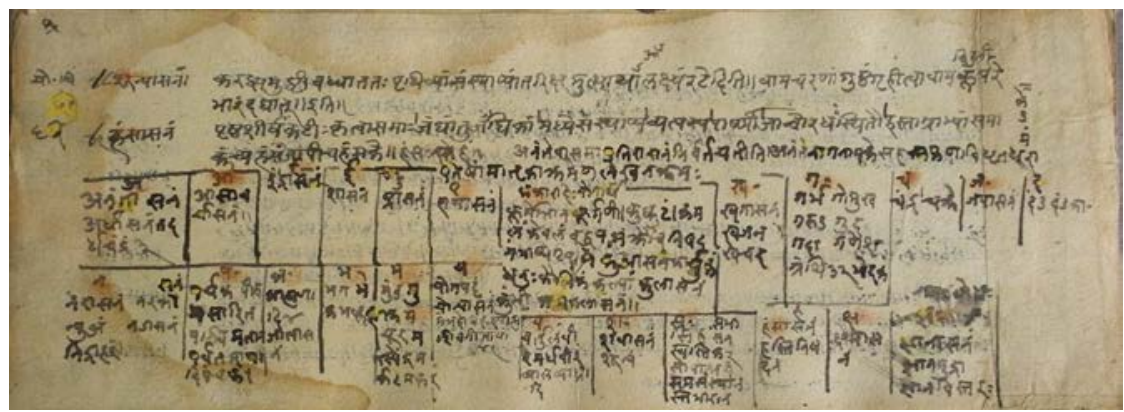

Figure 1: The Ujjain Manuscript of the Yogacintāmaṇi, fol. 62v (photograph: Jacqueline Hargreaves).

along the left side of each folio. The right side is blank, as though the scribe had intended to fill out descriptions for each āsana, but for some unknown reason never completed them. This hypothesis is supported by the fact that the very first àsana called anantāsana has its description included on the right side. ${ }^{45}$ Several folios have names written upside down on the right side as well. The writing deteriorates as the list progresses. Most of the folios on which this list is written appear to have been inserted at a later time, ${ }^{46}$ and the names of seventeen $\bar{a}$ sana-s have been repeated, which suggests that the scribe may have compiled this list from several unknown sources. Nonetheless, the scribe's hand remains consistent throughout the entire manuscript, though there are indications that he used a different pen at a later time to add corrections and marginal notes. Therefore, the third list can be dated reasonably close to the date of the manuscript.

The names of āsana-s in the Ujjain manuscript have been reproduced in Table 3 , below. I have divided the first list into two parts called $1 \mathrm{a}$ and $1 \mathrm{~b}$, respectively. List $1 \mathrm{a}$, which is written on folios $59 \mathrm{r}-61 \mathrm{v}$, includes the āsana-s common to all manuscripts of the Yogacintammani and it ends with the colophon quoted above. In a few cases, I have inserted the number " 2 " or " 3 " in parentheses next to the name of an āsana in this list to indicate those instances in which two or three different descriptions are given for the same āsana. List $1 \mathrm{~b}$, which is written on folios $61 \mathrm{v}-62 \mathrm{v}$ and $67 \mathrm{r}$, contains those $\bar{a}$ sana-s that have been added to list $1 \mathrm{a}$ by the scribe. The first seven were added as marginal and interlinear notes and the remaining twenty-one were written beneath the colophon (i.e., iti yogacintāmañāv āsanasangrahah). A transcription of the descriptions of these twentyeight āsana-s is presented in Appendix 1. List 2 has the names of the āsana-s in

45 For this description of anantāsana, see n. 50 .

46 For further information on this, see n. 36. 
the table on folio $62 \mathrm{v}$ (see Figure 1) and list 3 consists of the àsana-s listed on folios 63r-66bv. Please take note of the following symbols:

* = assana in list 2 and not in lists $1 \mathrm{a}$ and $1 \mathrm{~b}$

- = āsana in list 3 and not in lists $1 \mathrm{a}, 1 \mathrm{~b}$ and 2

$(\mathrm{r})=$ a repetition of a name of an āsana in list 3

\begin{tabular}{|c|c|c|c|c|}
\hline No. & List 1a & List $1 \mathrm{~b}$ & List 2 & List 3 \\
\hline 1 & mrgasvastika & kevalasvastika & ananga ${ }^{*}$ & ananta $\bullet$ \\
\hline 2 & ardhacandra & ardha & ardha & ardhacandra \\
\hline 3 & añjalikā & paryan்ka & ardhacandra & ardha \\
\hline 4 & daṇda & vīra & āsāvarī & ardhodaya ${ }^{\bullet}$ \\
\hline 5 & pītha & garuḍa & indra* & āsāvarī \\
\hline 6 & paryan்ka & markața & îśa* & indra \\
\hline 7 & yogapatța & garbha & ușțra & íśakāmaka• \\
\hline 8 & candrārdha & cakra & eṇa* & layodāsana• \\
\hline 9 & prasārita & daṇ̣a & kūrma & ușțra \\
\hline 10 & kūrma & sopāśraya & uttānakūrma & eṇa \\
\hline 11 & ardha & candra & kukkuṭa & kūrmottāna \\
\hline 12 & svastika (2) & krauñca & kamalam kevalam & kukkuṭa \\
\hline 13 & gomukha & hasti & baddhapadma & padmam kevalam \\
\hline 14 & vìra & ușțra & krauñca & baddhapadma \\
\hline 15 & simha & samasamsthāna & kubja & krauñca \\
\hline 16 & bhadra & bhaga & kārmukadhanus ${ }^{*}$ & kubja \\
\hline 17 & mukta & kubja & kaulika $^{*}$ & kāmukadhanus \\
\hline 18 & mayūra (2) & naḍa & kalpāa & kaulika \\
\hline 19 & kukkuṭa & garbha & kula* $^{*}$ & kalevara• \\
\hline 20 & uttānakūrma & nyubja & kumbhīra* $^{*}$ & kula \\
\hline 21 & dhanus & stambha & $\mathrm{kalā}^{\star}$ & kumbhīra \\
\hline 22 & matsysendra & sūnya & khaga $^{*}$ & khaga \\
\hline 23 & paścimatāna & hamsa & khañjana* & khañjana \\
\hline 24 & śava & gaṇeśa & khecara $^{*}$ & khecara \\
\hline 25 & naraka & guda & garbha & garuḍa \\
\hline 26 & siddha (3) & pārvatī & gomukha & garbha \\
\hline 27 & $\begin{array}{l}\text { padmāsanam } \\
\text { baddham }\end{array}$ & āsāvarī & garuḍa & gomukha \\
\hline 28 & kamala & nidrāhara & guda & guda \\
\hline 29 & $\begin{array}{l}\text { padmāsanam } \\
\text { kevalam (2) }\end{array}$ & & $\operatorname{gad} \bar{a}^{*}$ & gaṇeśa \\
\hline
\end{tabular}




\section{(Continued)}

\begin{tabular}{|c|c|c|c|c|}
\hline No. & List 1a & List $1 \mathrm{~b}$ & List 2 & List 3 \\
\hline 30 & & & ganeśa & granthibheda \\
\hline 31 & & & granthibhedaka* & gadā \\
\hline 32 & & & candra & kumbhīra (r) \\
\hline 33 & & & cakra & matsya \\
\hline 34 & & & japa $^{*}$ & kūrma \\
\hline 35 & & & daṇda & makara \\
\hline 36 & & & daṇḍakā ${ }^{*}$ & simha \\
\hline 37 & & & nara $^{*}$ & candra \\
\hline 38 & & & naraka & cakra \\
\hline 39 & & & nyubja* & japa \\
\hline 40 & & & naḍa & daṇda \\
\hline 41 & & & nidrāhara & daṇ̣akāā \\
\hline 42 & & & paryan்ka & khecarakāraka• \\
\hline 43 & & & pițha & kalpā \\
\hline 44 & & & prasārita & siddha \\
\hline 45 & & & paścimatāna & kālavaśakara• \\
\hline 46 & & & parvata $^{*}$ & nara \\
\hline 47 & & & prāṇādipañcaka ${ }^{*}$ & naraka \\
\hline 48 & & & brāhmaṇādi $4^{*}$ & nyubja \\
\hline 49 & & & bāla* & naḍa \\
\hline 50 & & & bhaga & nidrāhara \\
\hline 51 & & & bheka $^{*}$ & paryanika \\
\hline 52 & & & bhakta $^{*}$ & granthibheda (r) \\
\hline 53 & & & muṇda* & sarva• \\
\hline 54 & & & mukta & jñāna \\
\hline 55 & & & mayūra & kaulika (r) \\
\hline 56 & & & matsyendra & khañjana (r) \\
\hline 57 & & & markaṭa & pitṭa \\
\hline 58 & & & makara* & prasārita \\
\hline 59 & & & yogapațta & paścima \\
\hline 60 & & & yoni $^{*}$ & parvata \\
\hline 61 & & & $\begin{array}{l}\text { mantradoṣahara- } \\
\text { pātya* }\end{array}$ & prāṇādipañcaka \\
\hline 62 & & & vartula* $^{*}$ & śubha• \\
\hline 63 & & & vīra & parvata $(\mathrm{r})$ \\
\hline 64 & & & ardhavīra* & prāṇādi 5 (r) \\
\hline
\end{tabular}




\section{(Continued)}

\begin{tabular}{|c|c|c|c|c|}
\hline No. & List 1a & List $1 \mathrm{~b}$ & List 2 & List 3 \\
\hline 65 & & & vyāla* & $\begin{array}{l}\text { brāhmañā- } \\
\text { divarṇa } 4 \cdot\end{array}$ \\
\hline 66 & & & vyāghrādi* & jāti 5• \\
\hline 67 & & & śava & bhaga \\
\hline 68 & & & sūnya & bheka \\
\hline 69 & & & sabhā $^{*}$ & bhallūka• \\
\hline 70 & & & simpha & muṇ̣a \\
\hline 71 & & & svastika 2 & mukta \\
\hline 72 & & & sopāśraya & mayūra \\
\hline 73 & & & samasamsthāna & matsyendra \\
\hline 74 & & & stambha & markaṭa \\
\hline 75 & & & hamsa & yogapațta \\
\hline 76 & & & hastinișadana & yoni \\
\hline 77 & & & kṣamā $^{\star}$ & jātya (r) \\
\hline 78 & & & jñānabodha* & pāśava• \\
\hline 79 & & & jñānāsana* & śavasādhanāni \\
\hline 80 & & & jñānamudrā ${ }^{\star}$ & vartula \\
\hline 81 & & & jñānavistara* & vīra \\
\hline 82 & & & & vīrārdha \\
\hline 83 & & & & vyāla \\
\hline 84 & & & & vyāghra \\
\hline 85 & & & & śava \\
\hline 86 & & & & súnya \\
\hline 87 & & & & candra (r) \\
\hline 88 & & & & sūrya• \\
\hline 89 & & & & yoga• \\
\hline 90 & & & & gadā (r) \\
\hline 91 & & & & lakșya• \\
\hline 92 & & & & kula (r) \\
\hline 93 & & & & brāhmaṇa (r) \\
\hline 94 & & & & sabhā \\
\hline 95 & & & & simhha $(r)$ \\
\hline 96 & & & & svastika \\
\hline 97 & & & & sopāśraya \\
\hline 98 & & & & samasaṃsthāna \\
\hline 99 & & & & stambha \\
\hline 100 & & & & hamsa \\
\hline
\end{tabular}




\section{(Continued)}

\begin{tabular}{|l|l|l|l|l|}
\hline No. & List 1a & List $\mathbf{1 b}$ & List 2 & List 3 \\
\hline 101 & & & & hasti \\
\hline 102 & & & & kṣamā \\
\hline 103 & & & & jñāna \\
\hline 104 & & & & jñānamudrā \\
\hline 105 & & & & jñānabodha \\
\hline 106 & & & & jñānavistara \\
\hline 107 & & & & haṃsa (r) \\
\hline 108 & & & & bhallūka (r) \\
\hline 109 & & & & vartula (r) \\
\hline 110 & & & & kṣemā (r) \\
\hline 111 & & & & divya• \\
\hline 112 & & & & ardhodaya (r) \\
\hline
\end{tabular}

Table 3: Names of àsana-s in the Ujjain manuscript.

As mentioned above (p. 111), list 1a is the compilation of thirty-four āsana-s common to all manuscripts of the Yogacintāmaṇi. ${ }^{47}$ Its descriptions have been

47 The following additional remarks concern the names listed in column 1a of Table 3. Name no. 4: There is no description of dandāsana next to the name. Its absence may be due to the fact that dandāsana was included and described in list 1b. Name no. 11: In the list of names running down the left side of the folio, ardhāsana is an interlineal correction to the original name of vīrāsana. The description itself mentions ardhāsana (and not vīrāsana) and it is identical to the description of ardhāsana in the other manuscripts of the Yogacintāmani. Name no. 12: Both types of svastikāsana are found in the Yogayajjñavalkya and quoted with attribution in the Yogacintāmani. In the Ujjain manuscript, both have been written, but the first has been crossed out by a single line. Name no. 18: All manuscripts of the Yogacintāmani quote with attribution two descriptions of mayūrāsana. The first is from the Yogayajjñavalkya and the second is from the Hathapradīpikā. Name no. 24: After the description of śavāsana, which is found in other manuscripts of the Yogacintāmani, the Ujjain manuscript (fol. 61r) has inserted the following comment, which I have not traced to another text: "or [śavāsana] is as follows. Having lain supine on the ground, extending the legs and putting the hollowed hands on the chest and the gaze on the tip of the nose while visualising Śiva, the position in which [one is] on the back is śavāsana. This [äsana] is the destroyer of vitiated phlegm and the vātagranthi-disease in the chest, and it removes fatigue" (yathā vā $\mid$ uttānam urvyām śayanam vidhāya prasārya pādau karasampuṭam hṛdi| nāsāgram ādhāya dṛ́sạn smaran śivam prșțhe sthitir yatra śavāsanam hi tat $\|$ etad dhṛdikupitakaphavātagranthivibhedakam śramaharam ca \| Conj. urvyām : Codex urvyā; Corr. Preisendanz etad dhṛdi : Codex etat hrdi-). Name no. 26: Three versions of siddhāsana are included in all manuscripts of the Yogacintämani. The first is quoted with attribution to the Yogayajjnavalkya and the second to the Pavanayogasangraha, though the latter version probably derives from the Vivekamārtanda. The third version is quoted without attribution and I am yet to trace it to another yoga text: "Having placed the left ankle on the penis and the other ankle on that, this is Siddhāsana" (meḍhrād upari vinyasya savyam gulpham tathopari | gulphāntaram tu vinyasya siddhāsanam idam bhavet || Emend. medhrād : Codex medrād). Name no. 27: All 
quoted and attributed to various Sanskrit texts written before the sixteenth century. The Ujjain manuscript extends our knowledge of āsana-s practised in the seventeenth century by providing lists $1 \mathrm{~b}, 2$ and 3 . List $1 \mathrm{~b}$ consists of the twenty-eight āsana-s that have been added to list $1 \mathrm{a}^{48}$ List 2 adds thirty-nine $\bar{a}$ sana-s to lists $1 \mathrm{a}$ and $1 \mathrm{~b} .{ }^{49}$ List 3 adds another seventeen, which yields a total of one hundred and eighteen àsana-s in the Ujjain manuscript. ${ }^{50}$ Therefore, the

manuscripts of the Yogacintāmani quote with attribution this version of the bound lotus from the Yogayajjñavalkya. However, the Ujjain manuscript is unique in using the name padmāsanam baddham. Name no. 28: Quoted with attribution to the Matangah. Name no. 29: The Yogacintammani quotes these two versions of padmāsana and attributes the first to the Hathayoga, though this version of padmāsana, which involves holding the big toes with the hands, is found in the Vivekamārtanda and the Hathapradīpikā. The second, which does not involve holding the toes, is attributed to the Dattätreyayogaśästra. The Ujjain manuscript is unique in using the name padmāsanam kevalam.

48 In regard to list $1 \mathrm{~b}$, the name nyubja (no. 20 in column $1 \mathrm{~b}$ of Table 3 ) is a conjecture. See n. 150. 49 A number of names in column 2 of Table 3 are in need of further explanations and comments. Name no. 14: The name krauñcanisadana is followed by bhäsyagranthane, which refers to the inclusion of this posture in the commentary (bhāsya) of the Pātañjalayogaśāstra. Name no. 20: Conj. kumbhìra: Codex kumbhī+na. The ligature following bhi appears to be crossed out. I have conjectured kumbhī [rāsa]na based on a similar name in the third list. Name no. 31: A pose by the name granthibhedakāsana is quite conceivable (i. e., "the äsana of piercing the knots"), and might be a precedent for granthibhedanäsana apparently reported in the Sacitra Cauryaysin Asana, the Śrìyogakaustubha, the Kiranațīkā and the Yogamārgapradīpa (Gharote et al. 2006: 117-118). However, the scribe of the Ujjain manuscript has inserted the number 32 between granthi and bhedaka, and I cannot see a reason for this. Name no. 39: Emend. nyubja : Codex nyubhja. Name no. 48: Emend. brāhmanāäi : Codex brahmanāäi. Name no. 61: The manuscript is unclear here. I can only be certain of the following ligatures: ++ tradosaharapātya. This could be a scribal comment, rather than the name of an àsana because it has śivagit tàyàm (i. e., "in the Śivagìtă") written underneath it. Name no. 71: The number " 2 " is written in the manuscript (see Fig. 1). Name no. 78: Diagnostic Conj. jñānabodha : Codex $++b o d h a h$. I have conjectured jñannabodhah on the basis that $++b o d h a h$ has been written in the table's cell for āsana-s beginning with jina and jñānabodha appears in the third list.

50 Several names listed in column 3 require further explanations: Name no. 1: anantāsana is the only äsana to be described. Folio 63r: "Patañjali's aphorism [states,] 'Or meditative absorption in Ananta brings about āsana.' From this statement, the cause of āsana is [said to be] samädhi, in which the mind is on one thing, fixed [in this case] only on Ananta the leader of snakes, on whom the earth is held by his one thousand hoods, [so that] $\bar{a} s a n a$ becomes what will be described as steady and a cause of comfort" (anante vā samāpattir āsanam nirvartayati iti patañjalisūtram anante nāganāyake vidhṛtasahasraphaṇädharāmaṇdala eva niścalah samädhir ekacittah sthiram vakșamānam āsanam sukhakaram ca bhavati ity āsanakāranam ukteh || Conj. -phanādharāmandiala eva : Codex -phanāsu dharāmandale iva. Emend. -käranam : Codex-karanam). This description appears to have been based on a comment in Vācaspatimiśra's Tattvavaiśāradī 2.47 ([...] anante vā nāganāyake sthirataraphañāsahasravidhrtaviśsambharāmañale samāpannam cittam āsanam nirvartayatīti). Name no. 10: Beneath enāsana, there is an obscure comment, which has been slightly indented: kādeh yogahitam. The first compound appears to point out that several āsana-s which have names beginning with $k a$ follow at this point in the list. However, I am not sure what the second compound yogahita has to do with this. Name no. 11: Emend. kürmottā- 
Ujjain manuscript contains an additional eighty-four āsana-s to the thirty-four in other manuscripts of the Yogacintämani (i.e., list 1a). Eight of these have been taken from Vācaspatimiśra's Tattvavaiśáradī. However, I am yet to find the names of the other seventy-six additional āsana-s in any yoga text dated before the sixteenth century.

There are two more important pieces of information on àsana practice in the Ujjain manuscript. The first occurs in the description of nadāsana (the "reed pose") in list 1b. Its initial comment indicates that the pose and, perhaps, those that follow it were taught by Mohanadāsa: nadāsanam mohanadāsenok$t e^{51}|[\ldots]| \mid$.

A second similar comment is found on the folio on which this same list ends (i. e., 67r). At the centre top of the folio, as though it were a heading, is written the name of a yogi: lakṣmanadāsasvarayogī. Thus, it appears that the āsana-s numbered 44-49 have been attributed to Mohanadāsa and those numbered 5054 to Lakṣmanadāsa. Also, a marginal comment at the beginning of the section

na : Codex kūrmottāne. Name no. 14: Emend. baddhapadmam : Codex paddhapadmam. Name no. 15: The entry for krauñcanișadana on folio $64 \mathrm{r}$ has been split in half, with krauñcanișa written above danam bhāsye. For an explanation of the word bhāsya in a similar context, see note 48 on name no. 14 in column 2. Name no. 17: Monier-Williams (1899) cites kāmuka (s. v.) as a variant reading of kārmuka. Name no. 19: Diagnostic Conj. kalevara : Codex kalera. The word kalera (fol. 64r) is not found in any of the dictionaries. I have tentatively conjectured kalevara, but an āsana by this name is not attested elsewhere, as far as I am aware. Name no. 30: Under granthibheda (fol. 65r), three numbers separated by danda-s have been written: $21|7| 4$. Name no. 32: kumbhìrāsana and the four names following it have been written upside down on the right-hand side of folio 65r. Name no. 37: Emend. candra: Codex cāndra. Name no. 42: khecarakāraka and the four āsana-s following it have been written upside down on the right side of folio 65v. Name no. 45: Emend. kälavaśakara: Codex kālavaśakera. Name no. 52: granthibhedāsanam 32 and the four āsana-s following it have been written upside down on the right side of folio 66r. Note that the number "32" written after granthibhedāsanam corresponds to the number written between granthi and bhedaka in name no. 31 in column 2. Name no. 64: The manuscript has prānādyāsanāni 5. The plural suggests that this may be referring to more than one $\bar{a} s a n a$, perhaps, one for each of the five prāna-s. Name no. 65: The word varna and the number 4 indicate four $\bar{a} s a n a-s$, one for each of the castes. Name no. 66: One must wonder whether this is a reference to a fifth caste (i. e., the untouchables). Name no. 76: There is a faint marginal comment under yonyāsanam (fol. 65br): śivahitāyām pātha [|l]. Name no. 77: jātyāsana and the two āsana-s following it have been written upside down on the right side of folio $65 \mathrm{bv}$. Name no. 82: The first ligature $v \bar{i}$ is unclear. In fact, this name appears to have been written over another word, which makes it difficult to read. Name no. 87: candrāsana and the six āsana-s following it have been written upside down on the right side of fol. 66br. Name no. 93: Emend. brāhmaṇa: Codex brahmana. I presume that this is a repetition of brāhmanādivarna 4 (entry 65). Name no. 106: Diagnostic Conj. jñānavistara : Codex vistara. I have conjectured jñannavistara for vistara based on the fact that the poses preceding it begin with jñāna and the name jñānavistara is attested in list 2 . The four entries below vistara appear to form a comment and may not be names of āsana: evam $m \bar{a}+$ trā $++a m$ lakșanam lekhyam [ [|]. I have excluded them from the list.

51 This comment is on fol. 62r. 
on āsana quotes Lakṣmaṇadāsa, which suggests that his teachings may be connected in some way to the $\bar{a}$ sana-s that were added to the first list (i.e., list 1b). ${ }^{52}$ The dāsa suffix indicates these two yogis were Vaiṣnava. The fact that their āsana-s were added to a compilation on yoga authored by a Śaiva Advaitavedāntin demonstrates the willingness of yogis to combine yoga techniques from Śaiva and Vaiṣnava traditions. ${ }^{53}$ Also, apart from the attributions to mythical sages such as Vasiștha and Yãjñavalkya, the above attribution may be unique inasmuch as it ascribes specific āsana-s to what appears to be more recent yogis.

Though the additional āsana-s in the Ujjain manuscript are not found in earlier Sanskrit yoga texts, there are striking parallels in an illustrated manuscript of the Bahr al-Hayät held at the Chester Beatty Library. ${ }^{54}$ This Persian manuscript has been dated to c $1600-1605$ CE by art historians, ${ }^{55}$ and its text is a Persian rendering of an Arabic translation of a supposed Sanskrit yoga text called the Amrtakunda. Its fourth chapter describes and illustrates twenty-two yogic practices, some of which are āsana-s and others are prānāyāma-s performed in non-seated àsana-s.

The parallels occur with several of the àsana-s attributed to Mohanadāsa. ${ }^{56}$ One example is śünyāsana, which is depicted in the following detail of a painted folio in the Chester Beatty manuscript.

If one compares the image of Figure 2 to the description of śūnyāsana in the Ujjain manuscript, the similarities are clear:

Śūnyāsana: Having clenched the fists of both hands and then having placed them on the ground, the yogi should raise [his body] up into the air and exclaim "alakșya". Having

52 YC, ms. no. 3537, fol. 58v, bottom margin: "Lakșmanasvarayogĩ says, 'By eating sea salt and pepper, success in all āsana-s [is obtained], but not by [eating] rock salt.' Because of this, itching is [also] cured" (saindhavamarīcabhakșanena sarvāsanasiddhir na tu lavaneneti lakșmanasvarayogī || tena kaṇūūāśah).

53 An earlier example of this is the Śaiva-orientated Hathapradīikika, which, as noted above, incorporated verses on āsana-s from the Vaiṣnava Vasișthasaṃhitā.

54 I wish to thank James Mallinson for pointing out to me the parallels between the Ujjain manuscript and the illustrations in the Chester Beatty manuscript. Ernst (2003: 221, n. 47) has noted that this manuscript is not the only one with illustrations. He says: "Several manuscripts of the Persian translation contain miniature illustrations of the twenty-one asanas. One of these MSS is in the Chester Beatty Library in Dublin, another is in the Salar Jung Library in Hyderabad, a third is in the private collection of Simon Digby, and the fourth has recently been acquired by the University of North Carolina at Chapel Hill."

55 Leach 1995: 556.

56 Of the six āsana-s attributed to Mohanadāsa, the names of five correspond to names of yogic practices in the Bahrr al-Hayāt; i.e., garbhāsana, stambhāsana, śūnyāsana, hamsāsana and naulyāsana. The last is called bunawli in the Chester Beatty manuscript, but some of the other manuscripts of the Bahr al-Hayāt call it nauli (personal communication Mallinson, 9 April 2014). 


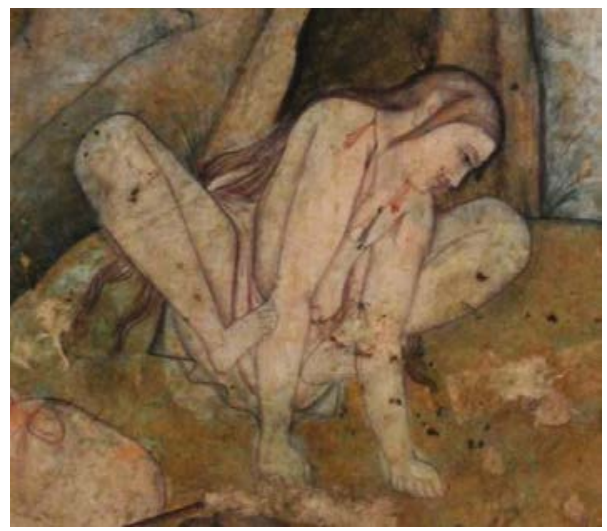

Figure 2: Śūnyāsana in the Chester Beatty manuscript of the Bahr al-Hayāt, fol. 27v.

taken the big toe of the left foot on the left elbow [and the right big toe on the right elbow $^{57}$, he should put the weight [of his body on the elbows]. ${ }^{58}$

The fact that some of the poses of the Ujjain manuscript are in the Bahr al-Hayatt confirms that these āsana-s existed in India in the seventeenth century. In many cases, the pictures of the Chester Beatty manuscript are invaluable for explaining the often obscure and corrupt Sanskrit descriptions of the āsana-s attributed to Mohanadāsa. A good example of this is garbhāsana. The Ujjain manuscript merely says:

The garbhāsana: Just as the shape of a foetus, so is [the shape of garbhāsana]. In it, one ought to do nirañjanakriyā and repetition [of a mantra] such as so 'ham and the like. ${ }^{59}$

The Ujjain manuscript does not explain the term nirañjanakriya $\bar{a}$. This practice is, however, described at length in the Bahr al-Hayāt, and garbhāsana is illustrated in the Chester Beatty manuscript.

The position of the yogi in garbhäsana is depicted in Figure 3. He is hunched over with his hands on his ears and his head between his knees. The following description is a translation of the Persian by Carl Ernst: ${ }^{60}$

57 It is clear from the illustration in the Chester Beatty manuscript as well as the description in the Bahr al-Hayāt that the right elbow and leg are required for śūnyāsana.

58 Fol. 62v: śünyāsanam - karadvayamuștī baddhvā tatah prthivyām samsthāpyāntariksam utthāpyālakșyạn rațed iti \|| vāmacaraṇānguștham gṛītvā vāmakūrpare bhāram dadyāt $\|$ iti $\|$.

59 Fol. 62r: garbhāsanam - garbhasaṃsthānam yathā tathā tat | tatra nirañjanakriyā kartavyā | so 'ham ityāder japah \| Corr. Preisendanz ityāder: Codex ityādeh.

60 The Smithsonian Institute has posted on its website Ernst's translations of the yogic practices in the Bahrr al-Hayāt. His translation of garbhāsana is available at http://www.asia.si.edu/ explore/yoga/chapter-4-bahr-al-hayat.asp\#seven (accessed 15 July 2014). 


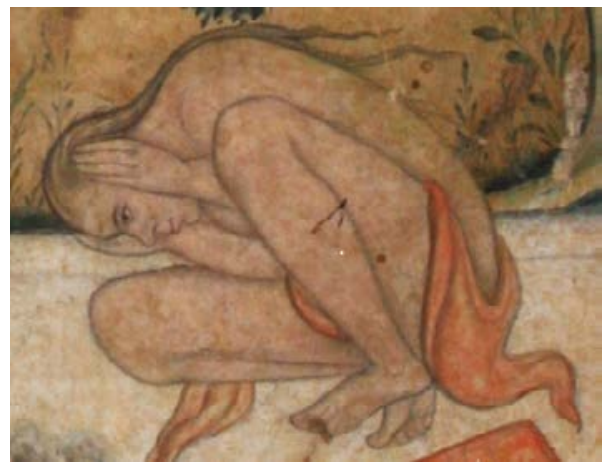

Figure 3: Garbhāsana in the Chester Beatty manuscript of the Bahr al-Hayāt, fol. 18r.

The word of recollection of Niranjan. When the seeker wishes to perform this activity, he should learn the Gharba àsana. They call it the Gharba àsana because when the child is in the womb of the mother it accomplishes it. One places the left foot on the right foot, holding the buttocks on both feet, holding the head evenly between the two knees, placing both elbows under the ribs, putting the hands over the ears, bringing the navel toward the spine. The breath of life (Ar. ramq) that appears from the navel they call Niranjan, which is an expression for the undifferentiated (la ta'ayyun). One holds the breath; one brings it in the midst of the belly. One takes it above from below, and below from above, in this exercise to such a degree that the inner eye, winged imagination, wandering reflection, and incomparable thought - all four - emerge from their restrictions. They enter witnessing of the spiritual state and become one.

The fact that the Ujjain manuscript and the Bahr al-Hayät both connect nirañjanakriyā with garbhāsana strongly suggests that they were drawing from the same system of yoga, which must have been prominent enough in the seventeenth century to have come to the notice of the Moghul court. The Ujjain manuscript does not provide us with a clear description of these practices. However, a description is found in another unpublished eighteenth-century Sanskrit yoga text called the Hathasanketacandrikā (HSC). This voluminous work was composed by an erudite Brahman named Sundaradeva who lived in Vārānasīi. ${ }^{61}$ His description of nirañjanakarma ${ }^{62}$ and garbhāsana has un-

61 The location of Sundaradeva, who was a Brahmin from the south, is confirmed by the final colophon of the HSC, ms. no. 2244, fol. 145v: "So ends the tenth chapter, called the explanation of the no-mind state, in the Hathasaiketacandrika, [which] was written by the physician Sundaradeva, the son of Govindadeva and the grandson of Viśvanāthadeva. Located in Kāśī, he was the ornament of southern Brahmins and sacred to the Kāśyapa clan" (iti śrīkāśyapagotrapavitradākșinātyadvijalalāmakāśisthaviśvanāthadevapautragovindadevasutasundaradevavaidyaviracitāyām haṭhasañketacandrikāyām amanaskatvavivecanam nāmopadeśo daśamah sampūrneyam hațhavidhicandrikā [|l] Corr. Preisendanz -padeśo : Codex -padeśah; Emend. daśamah : Codex daśah).

62 Elsewhere in this chapter on prānāyāma in the Hațhasanketacandrikā, other practices are 
mistakable similarities to the descriptions and illustration of these practices in the Bahr al-Hayāt. The parallels in the translation are set in bold:

Now, the àsana in which the "spotless action" [is performed]. Just as a child curls up and remains in a foetal position, so the yogi should practise nirañjanakarma in the foetal pose. Having put the left foot on the right, he should cover the buttocks with the heels and then move apānavāyu forcefully upwards again and again. Gradually he should put his head on his knees, draw the navel into the back [of the body,] cover the ears and eyes with the hands and remain thus. Then, a faint sound rises directly up from his navel and a pure and subtle light shines in front of him. The breath, having been restrained in the stomach, moves for a while in the abdomen. Having gone up again into the head, it goes [down] for a while into the stomach. When this technique of meditation on the pure [light] is continually performed, the best of yogis sees the hidden Brahma revealed. Passions along with desires disappear because of the yogi's practice [of this technique]. So too, delusion and impurity, and the individual soul becomes one with Siva. ${ }^{63}$

Not only is the posture the same, but also the cyclical movement of the breath between the abdomen and head. In the Hathasanketacandrikā, nirañjanakarmāsana is included in the section on prānāyāma, and there are further parallels between yogic practices in this section and those of the Bahr al-Hayat. These include bhujaingakarmāsanakumbha and hamsakarmāsanaprānāyāma in the Hathasanketacandrikā, which are similar to Bhuvangam and Hans respectively in the Bahrr al-Hayāt. Sundaradeva describes bhujañgakarmāsanakumbha as follows:

This has been taught in the scripture on [prognostication by means of the] breath [called] the Svarodaya: Having stood on both knees and having firmly closed the mouth, the wise man, [who] is very focused, should master the breath [flowing] through both

called kriyā (e.g., pūrakakriyā). So, karma (i.e., "action”) is simply a synonym for kriyā in this context.

63 HSC, ms. no. R3239, fols. 167-168 and ms. no. 2244, fol. 84r: atha nirañjanakarmāsanam \| bālako garbhaśayyāyām tișthet sankkucito yathā | tathā garbhāsane yogī nirañjanavidhị̣ bhajet || 124 || dattvā dakṣānghrau vāmānghrim pārṣnibhyām rundhayet sphijau | apānam ūrdhvam ca kuryād vāram vāram tato balāt || 125 || jānvante mastakaṃ dattvā nābhiṃ prșțhe vikarșayet |pānibhyām cchādayet karnau netre tiṣthed iti kramāt || 126 || tadā nābheh sakāśāt tu śabdo 'syottișthate sa 'nu h | nirañjanam jyotir agre sūkșmaṃ cāsya parisphuret || 127 || ruddho 'ntar udare vāyur jațarāntar bhraman muhuh | ùrdhvam gatvā mastakānte muhur yāty udarāntare || 128 || śaśvad vidhim imam kṛtvā nirañjanavicintanam | labhate brahma yad guptam prakațạ̣ sādhakottamah || 129 || naśyanti kāmabhịh kopā abhyāsenāsya yoginaḥ | moho malinatā naśyec chivajīivaikyatā bhavet || 130 || iti nirañjanakarmāsanam ||. Variant readings: 125a-b dakșānghrau vāmānghrim pārșnibhyāṃ rundhayet sphijau] 2244 : datvā dakṣānghrivāmānghripārṣnibhyāṃ rundhayet sinau 3239. 126d iti kramāt] Diagnostic Conj. : iti kramaih 2244 : atikramaih 3239. 127a-b sakāśāt tu śabdo 'syottișthate sa 'ṇuḥ 2244 : sakāsátva śabdo 'syottișthakonyanuh $3239.127 \mathrm{~d}$ cāsya parisphuret] 2244 : vāra ca parisphuret 3239. 128a ruddho 'ntar] 2244 : randhrātar 3239. 128a vāyur] 2244 : vāyu 3239. 128b jațarāntar bhraman muhuh ] emend. : jațharāṃrbhraman muhuh 2244 : jațharābhramaran maruh 3239. 
nostrils. Having drawn the breath into the navel, he should practise in reverse. Having turned it upwards, the sage should repeatedly force it [further up]. When he knows [the breath] is situated at the tenth [door at the crown of the head], he should gradually release it. When the breath has gone below the navel, then, having again turned it upwards by that same action, he should draw it [further] upwards. If the disciplined ascetic does this technique repeatedly, he first balances nasal dominance (svara). ${ }^{64}$ The practitioner should hold the breath according to his capacity, [doing so] gradually, not hurriedly. By this method, he should inhale deeply and gradually. Having given his mind to this action, the practitioner should accomplish it. When [this] action has been mastered, then, having held the breath for up to one day, he should remain comfortably [for longer] in order to increase his progress in the practice. As the yogi holds the breath, making it longer, so he should stop it from moving out for five or six days. By this [method] the practitioner certainly gains a long life. Thus, the retention in [this] practice is called the âsana whose action is like a serpent's. ${ }^{65}$

The Persian description of the "serpent" practice (bhuvanga) in the Bahr alHayāt has clear parallels (marked in bold) with the above passage:

The word of recollection of bhuvangam. When one wishes to perform the bhuvangam practice - and bhuvangam is the expression for the serpent ( $m \bar{a} r)$ - just as the serpent inhales, the wayfarer must act according to this path and comprehend it. He sits on both

64 I am not sure of the meaning of svaram yāvat tu bibhryāt. I have understood svara as nasal dominance according to its use in Svaraśāstra, in which this technique is supposedly taught. However, I am yet to find another instance of the verb $b h r$ with this meaning in a yoga text.

65 HSC, ms. no. R3239, fols. $165-166$ and ms. no. 2244, fol. 83r-83v: tad uktam svarodaye svaraśāstre || sthitvā jānudvaye vaktram ārudhya sudṛ̣̂hạ̣ sudhīh | nāsārandhrayugād vāyum sādhayet susamāhitah || 106 || ākrssya vāyum nābhyantam vidadhìta vilomatah | parāurtrtyordhvam ādadhyād balena satatạ̣ munih || 107 || daśamāntagatam jūātvā śanair anu ca mocayet | yadā nābher adho yāto vāyus tạ̣ tu tad̄a punah || 108 || amunā karmanaivordhvam parāvrtyordhvam āharet | amum vidhị yadi muhuh karoty abhyāsavān yatih || 109 || svaram tāvat tu bibhryād yāvacchakti samìranam| saṃrodhayet sādhako 'yam śanair na tvarayā punah $\| 110$ || anena vidhinā bhüri gṛhn̄yāt pūrakam śanaih | asyām kriyāyām hṛ dattvā sādhakah sādhayet kriyām || 111 || yadā haste kriyā yātā tadā hy ekadināvadhi | ruddhvā tișthet sukham vāyum abhyāsakramam vardhitum || 112 || yathādhikam svaram yogī kurvan saṃrodhayet tathā| vāyum șaṭañcadivasān rodhayed bahiścarāt || 113 || anena dìrgham àyusyam sādhakasya bhaved dhruvam iti || bhujangakarmāsanākhyo 'bhyāsakumbhakah \|. Variant readings: svaraśāstre] 3239 : svaraśāstre bhujangakarmāsanakuṃbhah 2244. 106b ārudhya] Conj. : āmuḍa 2244, 3239. 106d sādhayet] 3239 : sādhayot 2244. 107a vāyum ] $2244:$ vāyu 3239. 107b vidadhìta vilomatah ] Diagnostic Conj. Mallinson: vidhāyāvilomatah (hypometrical) 2244 : vidhāyād avilomatah 3239. 107d munih ] 2244 : munā 3239. 108a daśamāntagatam ] 3239 : daśamānte gatam 2244. 108b anu ca mocayat] 2244 : anu ca yācayet 3239. 110a tāvat tu bibhryād] Conj. : yāvat tu bibhryād 2244 : yāvad bibhryā 3239. 111a vidhinā bhūri] Corr. : vidhinād bhūri 2244 : vidhinā mūri 3239. 111b sādhakaḥ sādhayet] $2244:$ sādhakās sādhaye 3239. 112a haste kriyā yātā] 2244 : hase kriyā mātā 3239. 112b tadā hy ekadināvadhi] 2244 : tadā ekadināvadhi 3239.112c ruddhvā] 2244 : raddhvā 3239. 112d abhyāsakramam vardhitum] 3239 : vāyum krama 'bhyāsakramavardhitam (hypermetrical) 2244. 113b kurvan] 2244 : kurvant 3239. 113d carāt] 3239 : caret 2244. bhujaṅgakarmāsanākhyo] 2244 : bhujañgakarmāsanābhyo 3239. 
knees, holding the mouth closed; he inhales by way of the nostrils, taking it beneath the navel, bringing it up from the navel by force to the base of the brain. From there, gradually one releases it, and it reaches below the navel. Again one brings up by force, and one repeats this in this manner, as long as one is able. One holds the breath that was mentioned, not letting it go out by way of the nostril and mouth. When one is no longer able [to hold it], one lets out the breath by way of the nostrils with a loud voice, again from the top, and just as is mentioned, one begins [again]. Some practitioners carry this subtle practice to such an extent that they remain for one or two days with a single breath, and some do more. ${ }^{66}$

There are also loose parallels between hamsakarmāsanaprānāyāma in the $\mathrm{Ha}$ thasanketacandrikā and Hans in the Bahrr al-Hayāt. The former states:

In his body, $\dagger[\ldots] \dagger$ the wise man should hold a vajramallaka. [With his senses] controlled, he should begin the practice of Hamsa without attachment to the world. He should then hold his hips, back and upper limbs straight. [With his mind] focused, he should place one shin above the [other] shin. He should firmly place the heel of his left foot on the base of the right knee, and he should fix the heel of his right foot with the left knee. He should repeat the ajapa [mantra], while perceiving the nature of Hamsa. Hamsa is the self in the form of the breath. He should meditate on it as the self. By means of Hamsa's $\bar{a}$ sana, ${ }^{67}$ the sage who is constantly meditating on Hamsa and repeating the mantra, "Hamsa, Hamsa," will obtain his own nature. [Such yogis] destroy impurity, dullness and diseases as well as [other] impurities. Thus, prānāyāma [performed] in hamsakarmāsana is useful for purification of the channels [of vitality in the body.] ${ }^{68}$

The relevant section of the description of Hans in the Bahr al-Hayāt (parallels are in bold) is as follows:

[...] The posture of this practice (karma) they call sahaj äsana; let it be unveiled! One holds the head, waist, and back even, and one meditates, placing one shin over the other, holding the left ankle under the point of the right knee, and placing the right

66 The translation by Ernst is available at http://www.asia.si.edu/explore/yoga/chapter-4-bahral-hayat.asp\#fifteen (accessed 15 July 2014).

67 In this context, the term pittha is a synonym for āsana. Cf. HP 1.29, 32, 41 and 70.

68 HSC, ms. No. R3239, fols. 165-166 and ms. No. 2244, fol. 83r-83v: ainge †bhūtipurālāpya $\dagger$ dhārayed vajramallakam | vihāya lokasañgam jño hamsakarmārabhed vaśī || 119 || kațiprșthottamāngāni samāni bibhryāt tatah | samāhitas samvidadhyāt piṇdikopari piṇ̣̂kām || 120 || dakṣajānutale vāmapatpārṣnịn sthāpayed dṛ̣ham | dakṣānghripārṣnikạ̣ vāmajānunā parikalpayet || 121 || ajapām prajaped dhamsasvarūpam sa samīkșayan| svararūpo haṃsa ātmā tam àtmānam vicintayet || 122 || anena haṃsapịthena haṃsaṃ dhyāyan japan manum | hamsa hamseti satatam svarūpam munir āpnuyāt || 123 || mālinyajadatārogān naśyanti kaluṣāṇi ceti | iti hamsakarmāsanaprānāyāmo nādî́śuddhyupayogikah ||. Variant readings: 119c lokasañgạ̣ ] 2244 : lokasañga 3239. 120d piṇ̦ikopari piṇdakām] 2244 : pindakopari piṇakīm 3239. 121a dakșajānutale] 2244 : dakșapādatale 3239. 122a -japed dhamsa- ] Corr. Preisendanz : -japed hamsa- Codex. 123a hamsapithena hamsam ] 2244 : hamsayogena hasan 3239. 124b mālinyajadatārogān naśyanti] Corr. : mālinyadajatārogān naśyanti 3239 : mālinyajadatārogān syanti (hypometrical) 2244. I wish to thank James Mallinson for his comments on the above passages from the Hațasañketacandrikā. 
ankle under the point of the left knee, clasping both hands together. When exhaling, one says hans, and hans is an expression for "the spiritual Lord" (Ar. rabb rūhī). When inhaling, one says so ham, and so ham is the expression for "Lord of Lords" (Ar. rabb al$\operatorname{arba\overline {b}})[\ldots]^{69}$

These kriyā-s, which combine elaborate prānāyāma techniques with complex $\bar{a}$ sana-s, demonstrate the growing sophistication of Hatha Yoga techniques after the sixteenth century, in addition to the proliferation of àsana-s evinced by the Ujjain manuscript. Far from falling into decline, the techniques of Hatha Yoga evolved as they were appropriated by erudite Brahmins, such as Sundaradeva, whose work must have made Hațha Yoga more accessible and appealing to a learned audience.

\subsection{The Hațhapradīpikā-Siddhāntamuktāvalī}

The second unpublished manuscript discussed in the present chapter is an extended version of the Hathapradipikä. This work is also called the Siddhäntamuktāvalī in its colophons. It has six chapters and a total of 1553 verses, which is over a thousand more than the number of verses in standard versions of the Hathapradīpikā. A scribal comment after the final colophon indicates clearly that the manuscript was completed in samvat 1765 (1708 CE).$^{70}$ Therefore, the extra verses of this text provide a window into the late seventeenth and early eighteenth centuries. The chapter on āsana describes more than eighty-two postures in addition to the fifteen in the standard Hathapradipika.$^{71}$ The names of the additional āsana-s are listed in Table 4. Those from the Hathapradīpikā are marked by an asterisk $\left({ }^{*}\right){ }^{72}$

69 The translation by Ernst is available at http://www.asia.si.edu/explore/yoga/chapter-4-bahral-hayat.asp\#four (accessed 15 July 2014).

70 SMĀ fol. 171v, ll. 2-7: iti śrīsahajanāthasisyeṇa śrīsvātmārāmayogīndreṇa viracitāyām hathapradīpikāyām siddhāntamuktāvalyām șașthopadeśah || iti || śrīmanmahārājādhirājajīśrījayasiṃhadevajīkasyājñayā likhitam idam tulärāmeṇa || saṃvat 1765 varșe caitre māse $k r s \underline{n}$ e pakșe 10. The date corresponds to Sunday, 4 April 1708 in the amānta naming system.

71 For the descriptions of the àsana-s, see SMĀ, ms. no. 6756, fols. 26r, 1. $6-49 \mathrm{v}, 1.7$. The exact number of $\bar{a}$ sana-s in this manuscript cannot be calculated owing to a missing folio (i.e., fol. 31) which would have descriptions of another 3-4 postures.

72 On the names of a asana-s listed in Table 4 the following explanations and philological observations are necessary. No. 1: The first description of svastikāsana is that of the Hathapradipika. The second, which is quoted without attribution, is identical with that in the Yogayājñavalkya. No. 5: The first description of gomukhāsana is that of the Hathapradīpikā. The second, which is quoted without attribution, is identical with that in the Yogayajjñavalkya. No. 18: The first description of paścimatānāsana is that of the Hathapradīpikā. A second follows, which is identical with the description in the Śivasamhitā. No. 19: The term kandoraka may be a wrong spelling for kandüraka. No. 28: This äsana is spelt jaityāsana in 


\begin{tabular}{|c|c|c|c|}
\hline No. & Name & No. & Name \\
\hline 1 & svastika $(2)^{\star}$ & 48 & prabhākara \\
\hline 2 & vīra $^{*}$ & 49 & jarā \\
\hline 3 & agnikuṇḍa & 50 & siṃhamukha \\
\hline 4 & yogin̄̄ & 51 & nāgaphaṇa \\
\hline 5 & gomukha $(2)^{*}$ & 52 & brahma \\
\hline 6 & tūra & 53 & kurarī \\
\hline 7 & kan்kaṇa & 54 & cakravāka \\
\hline 8 & gandharva & 55 & vaiśākhī \\
\hline 9 & śiva & 56 & cakora \\
\hline 10 & savitrīsamādhi & 57 & koka \\
\hline 11 & maṇibandha & 58 & śukakīra \\
\hline 12 & padmaprakāśa & 59 & ākāšatāna \\
\hline 13 & padmaśańkha & 60 & kuhī \\
\hline 14 & padmanābhabandha & 61 & kilakila \\
\hline 15 & bhairava & 62 & daṃśa \\
\hline 16 & matsyendra* & 63 & siddhamuktāvalī \\
\hline 17 & matsyendrapițhabandha & 64 & kukkuța* \\
\hline 18 & paścimatāna $(2)^{\star}$ & 65 & mayūra* $^{*}$ \\
\hline 19 & kandoraka & 66 & mastaka \\
\hline 20 & yoni & 67 & ātmārāma \\
\hline$\dagger \ldots \dagger$ & (missing folio) & 68 & mṛttikābhañjaka \\
\hline 21 & vibhūṣā & 69 & phoḍya \\
\hline 22 & saptarsi & 70 & bhagalabandha \\
\hline 23 & kadalī & 71 & nidrānāśana \\
\hline 24 & pūrva & 72 & [uttāna]kūrma* \\
\hline 25 & tryambaka & 73 & vṛścika \\
\hline
\end{tabular}

the heading but jityāsana within the verse itself. No. 33: Also spelt goraksajañjālaka within the verse itself. No. 50: Diagnostic Conj. simnhamukhāsana: Codex sīhamurgāsana. The name of this äsana is doubtful because the heading is sihamurgäsana, but the name within the verse itself is paksyāsana, which is also the name of another āsana in this text (see No. 74). The word sìha is a Prakrit form of siṃha but I am not sure of murga. It might be a corruption of mārga, but simhamukha occurs in many texts and makes better sense in the context of āsana. No. 53: In the heading for the verse, this äsana is misspelt as kurakalāsana. In the verse itself, the name is kuraryāsana. No. 58: This äsana is referred to as śukakira in the heading but as śukāsana within the verse itself. No. 62: Emend. damśsa : Codex damsa. No. 71: Emend. nidrānāśanam : Codex nidrānāsasanaṃ. No. 72: The heading for this pose is kūrmāsana, but the verse following it is the Hathapradīpikä's verse on uttānakürmāsana. No. 77: päradhika is spelt as pāradhī àsana in the heading and päradhika in the verse itself. No. 79: The heading has gohī àsana but the verse describes śiśumārāsana. The former may be an alternate name for the latter. No. 81: The heading has dṛkșäsana but the name in the verse is nāsāgradṛkșāsana. 
(Continued)

\begin{tabular}{|c|c|c|c|}
\hline No. & Name & No. & Name \\
\hline 26 & śoșa & 74 & pakși \\
\hline 27 & tìkṣṇa & 75 & abhika \\
\hline 28 & jaityāsana & 76 & ājagara \\
\hline 29 & bhaga & 77 & pāradhika \\
\hline 30 & kūrma & 78 & ūrṇanābhi \\
\hline 31 & pan்kaja & 79 & śiśumāra \\
\hline 32 & pārvatī & 80 & kapālī \\
\hline 33 & gorakṣajañjālī & 81 & nāsāgradṛkṣa \\
\hline 34 & kapila & 82 & tapa \\
\hline 35 & kāka & 83 & sañgrāma \\
\hline 36 & garuḍa & 84 & valījasya \\
\hline 37 & aghora & 85 & vikața \\
\hline 38 & jāmā & 86 & karma \\
\hline 39 & sārasa & 87 & nāgabodha \\
\hline 40 & dhātra & 88 & hamsa \\
\hline 41 & linga & 89 & sarpa \\
\hline 42 & prșțhabandha & 90 & madhupa \\
\hline 43 & viṣnu & 91 & siddha $(2)^{\star}$ \\
\hline 44 & gopī & 92 & padma $(2)^{*}$ \\
\hline 45 & vaitālanāma & 93 & simha* \\
\hline 46 & gaṇeśa & 94 & bhadra $^{*}$ \\
\hline 47 & yogapadayoga & 95 & śava* \\
\hline
\end{tabular}

Table 4: The names of àsana-s taught in the Siddhāntamuktāvalī.

Over half of the additional poses are unique and some others resemble postures in other yoga texts, but have unique names. This extended version of the $\mathrm{Ha}$ thapradīpikā is further proof of the continuing innovation and growth of àsana practice in Hatha Yoga during the seventeenth century. Unfortunately, until another manuscript of it is found, it is unlikely to be published because the only available manuscript from Rajasthan is heavily tainted by scribal errors and is missing three folios.

\subsection{The Hathābhyāsapaddhati}

The third unpublished manuscript is of a text called the Hathābhyāsapaddhati. Its opening lines leave no question as to the name of the author and the work: 
For those afflicted by the pain of Samsara; those completely attached to sense objects; those obsessed with women; those fallen from their caste and [even] those who do rather egregious actions; ${ }^{73}$ for their sake, this Hathābhyāsapaddhati was composed by Kapālakuranțaka. Its topics and the techniques of the practice are written [here]. ${ }^{74}$

In spite of the problems with the above Sanskrit sentence as it appears in the manuscript, ${ }^{75}$ the name of the author and the title of the work are clear. ${ }^{76}$ The

73 The meaning of săhasakarma is not entirely clear here. As a broad category classifying actions, sāhasa can include various crimes of violence and cruelty, ranging from destruction of property and irrigation canals to adultery, rape and murder. For further examples, see the sāhasaprakarana (p. 74) of the Vyavahāramālā (I wish to thank Shaman Hatley for this reference). However, in the context of Hatha Yoga, the term can mean just "bold" or "rash". In the Hațapradīpika (1.16), sāhasa is mentioned as a positive characteristic of the hathayogi. It is understood by Brahmānanda in his Jyotsnā as: "sāhasa is acting boldly, having not considered whether [the action] can or cannot be accomplished" (sādhyatvāsādhyatve aparibhāvya sahasā pravrttih sāhasam). The term sāhasa is also used in the Hațhäbhyāsapaddhati's section on vajrolimudrā (fol. 28r), which states, "It is sufficiently auspicious that by practising thus, by Î́vara's compassion, by being fit for the substances, by great fortitude and by understanding the teachings of the guru, [vajroli] will be perfected [even] by those whose actions are egregrious" (enam abhyāsena iśsarakrpayā dravyānulyena atidhairyeña sāhasakarmānām gurūktigrahaṇena siddhā bhavișatīty alam mañgalam \| Emend. evam : Codex enam). In the context of vajrolī, sāhasa probably refers to those who do not practise celibacy (brahmacarya). However, in the opening lines of the Hațhäbhyāsapaddhati the more general meaning of săhasa (i. e., egregious actions) seems to complete the range of people mentioned here, which starts with the most general category of person who needs salvation and ends with the most extreme.

74 HAP, fol. 1v, ll. 2-4: saṃsāratāpataptānām || atyantavisayasaktānām || strainānām jātibhraștānām || atisāhasakarmakarț̣nām || tatkṛte || iyam kapālakuranțakakrtahathābhyāsapaddhatir [\|] tadgatapadārthāh sādhanakarmāṇi ca likhyante \|. I have made a number of corrections and conjectures. These are: Corr. kartṛn̄amm: Codex kartrṇām. Corr. tatkrte : Codex tatkate. Emend. -paddhatir : Codex -paddhatar. Conj. Dominic Goodall tadgata- : Codex gata-. Emend. likhyante : Codex likhyate.

75 The compounds gatapadārthāh and sädhanakarmāni are strange and incongruous with the singular verb. The iyam indicates that -paddhatih was probably the subject. The reading -hațābhyāsapaddhatigatapadārthāh (i.e., "those subjects in the Hațhābhyāsapaddhati") may have been intended but iyam and the singular verb seem to indicate otherwise. It is possible that gatapadārthāh and sādhanakarmāni are clumsy interpolations, which were made by the scribe to indicate that the text in the manuscript is only part of the Hath $\bar{a}$ bhyāsapaddhati (personal communication Mallinson, 4 October 2013). The fact that the manuscript has no final colophon and finishes abruptly with an explanation of viparitakaraṇi (i.e., the last words of the text are viparìtakaranīmudrā bhavati \|| -karañī-] Corr. Preisendanz: karani-Codex) strongly suggests that it is incomplete. One would expect to find sections on dhyāna and samädhi at the end of a work like this.

76 The name Kapālakurantaka is not found in any other yoga text, as far as I am aware, but I am grateful to Mallinson for pointing out that korantaka is the name of one of the Siddhas known to have taught Hatha Yoga according to HP 1.6c. The Kaivalyadhama edition (1998:3) reports the alternate spellings of kauranthaka and kaurantaka in its apparatus. The similar name of Korandaka for a Siddha of Hațha Yoga is recorded in the Hatharatnāvali (1.81c), though many manuscripts of this text also have gonandaka (Gharote 2009: 35). In his edition of this text, Gharote speculates that the Kapālakuranțakahațābhyāsapaddhati may be ascribed to 
manuscript appears to be incomplete because there is no final colophon, nor is there a scribal comment indicating the date.

The paper is unusually thin for a pre-twentieth century manuscript, which might suggest a more modern paper-making technology, ${ }^{77}$ but it has the blemishes and uneven texture of hand-made paper. Unfortunately, the manuscript is undated. However, the text may date to the eighteenth century, based on a parallel in another text, which I shall discuss below.

A paddhati usually presents the "scattered instructions of a body of texts in an order that facilitates their practical application."78 The Hațābhyāsapaddhati appears to be an exception to this inasmuch as it does not quote from earlier yoga texts. However, true to its designation as a paddhati, it does present the practice of Hatha Yoga in a systematic way, beginning with yama, niyama, āsana, satkarma, prāṇāyāma and finishing abruptly with mudrā. The text, as it is written in the manuscript, appears to be incomplete and may be a truncated form of an earlier work on yoga or an unfinished attempt to reorganise the contents of an earlier work into the form of a paddhati. ${ }^{79}$

The section on āsana practice has descriptions of one hundred and twelve postures and space for illustrations that were never made. Most of the äsana-s in the Hathābhyāsapaddhati are not found in earlier yoga texts, including the unpublished ones mentioned in this paper. The exceptions are a dozen or so $\bar{a}$ sana-s common in Hatha texts such as the Hathapradīpikā. However, nearly all the names and descriptions of the Hathābhyāsapaddhati's āsana-s are included in a more recent compendium called the Śritattvanidhi (ŚTN) ascribed to a Mahārāja of Mysore who ruled from 1799 to 1868 (Mummaḍi Kṛ̣nạaāja Woḍeyar III). ${ }^{80}$ Therefore, the Śitattvanidhi was probably written in the mid nineteenth century.

The table of contents in an early publication of the Śritattvanidhi indicates that it is a digest of a number of wide-ranging topics. ${ }^{81}$ Sjoman (1999) has worked on the Śritattvanidhi's chapter on āsana practice. Sjoman's book includes photographs of the illustrations of àsana-s from a manuscript of the Śitattvanidhi held at a library in Mysore. ${ }^{82}$ These illustrated folios, which include the Sanskrit

this Siddha. The name may also correspond to Korandia who is listed among Siddhas in Änandakanda 1.3.49c (see White 1996: 83-86).

77 I wish to thank Dominik Wujastyk for pointing this out to me (personal communication, 10 September 2013).

78 Sanderson 2004: 356-357, n. 19.

79 On the incompleteness of the Hațhābhyāsapaddhati, see n. 75.

80 This is according to the annals of the Mysore Palace (see Iyer \& Nanjundayya 1935: 49).

81 Śrīkṛ̣nadāsa 1884: 1-44.

82 One photograph appears to be from a different manuscript. Sjoman (1999: 40) says that he photographed two manuscripts at the Sarasvati Bhandar Library in Mysore. One is of the 
descriptions of each àsana in Telugu script, indicate that the Śittattvanidhi has reproduced all except one of the āsana-s in the Hathābhyāsapaddhati, because their descriptions are identical. However, an important difference in the presentation of a sana practice in these texts is the order in which they appear. In the table below, the names of the àsana-s have been listed according to their order in the Hathābhyāsapaddhati, and their position in the Śritattvanidhi is indicated by the number on the right. The one pose not in the Sritattvanidhi is marked by an asterisk $\left({ }^{*}\right){ }^{83}$

\begin{tabular}{|c|c|c|c|c|c|}
\hline No./HAP & Name & No./ŚTN & No./HAP & Name & No./ŚTN \\
\hline 1 & vṛṣapādakșepa & 81 & 57 & mālā & 44 \\
\hline 2 & parigha & 11 & 58 & hamsa & 45 \\
\hline 3 & paraśvadha & 16 & 59 & vānara & 37 \\
\hline 4 & ananta & 1 & 60 & parvata & 43 \\
\hline 5 & añkuśa & 3 & 61 & pāśa & 47 \\
\hline 6 & śvottāna & 2 & 62 & kādamba & 91 \\
\hline 7 & mārjārottāna & 82 & 63 & kāñcī & 92 \\
\hline 8 & vrrka & 10 & 64 & angamoțana & 116 \\
\hline 9 & trikūṭa & 21 & 65 & ucchīrșaka & 48 \\
\hline 10 & markaṭa & 83 & 66 & (unnamed) & 117 \\
\hline 11 & nauka & 4 & 67 & pādukā & 41 \\
\hline 12 & tiryan்nauka & 84 & 68 & graha & 50 \\
\hline 13 & dhvaja & 7 & 69 & parpața & 93 \\
\hline 14 & naraka & 8 & 70 & aśva & 73 \\
\hline 15 & lāngala & 17 & 71 & dviśīiș̣a & 46 \\
\hline 16 & paryañka & 5 & 72 & kubja & 52 \\
\hline
\end{tabular}

Srìtattvanidhi and the other is of the Hațhayogapradīpikā, the text of which is different from the well-known Hathapradīikika.

83 There are a number of differences between the names of àsana-s in the Hathābhyāsapaddhati and in the Śritattvanidhi. These call for the following additional remarks: No. 6: This pose is called uttāna in the Śritattvanidhi. No. 10: This pose is called kāmapițthāsana in the Śrītattvanidhi. No. 47: The description of this unnamed pose is the same as nyubjäsana in the Śritattvanidhi. No. 48: The description of this unnamed pose is the same as garbhāsana in the Śritattvanidhi. No. 51: The description of this unnamed pose is the same as dhanurāsana in the Śritattvanidhi. No. 55: The description of this unnamed pose is the same as pädahastasamyogāsana in the Śritattvanidhi. No. 64: This pose is called hastängulibaddha in the Śrītattvanidhi. No. 66: The description of this unnamed pose is the same as hrjjänusamyogāsana in the Sritattvanidhi. No. 74: The description of this unnamed pose agrees with that of the preńkhāsana in the Śritattvanidhi. There are two poses by this name in the Śrìtattvanidhi (see Sjoman 1999: 85). No. 76: This pose is called vimalāsana in the Śrittattvanidhi. No. 86: This pose is called uḍ̂anāsana in the Śritattvanidhi. No. 95: The description of this unnamed pose is the same as that of dandāsana in the Śritattvanidhi. 


\section{(Continued)}

\begin{tabular}{|c|c|c|c|c|c|}
\hline No./HAP & Name & No./ŚTN & No./HAP & Name & No./ŚTN \\
\hline 17 & vetra & 9 & 73 & prenkha & 94 \\
\hline 18 & kanduka & 6 & 74 & (unnamed) & 118 \\
\hline 19 & uttānakūrma & 85 & 75 & utpị̣̄a & 53 \\
\hline 20 & virata & 86 & 76 & vimāna & 51 \\
\hline 21 & dṛșada & 21 & 77 & kapotapițaka & 57 \\
\hline 22 & luṭhana & 20 & 78 & ardhacandra & 95 \\
\hline 23 & sarața & 12 & 79 & śañku & 22 \\
\hline 24 & matsya & 14 & 80 & tāṇ̣̣ava & 55 \\
\hline 25 & gaja & 13 & 81 & trivikrama & 62 \\
\hline 26 & tarakṣu & 15 & 82 & utthānotthāna & 106 \\
\hline 27 & ṛkṣa & 18 & 83 & ālinga & 96 \\
\hline 28 & śaśa & 24 & 84 & bālālingana & 97 \\
\hline 29 & ratha & 23 & 85 & kaupīna & 110 \\
\hline 30 & meșa & 87 & 86 & dehalyullanghana & 119 \\
\hline 31 & aja & 25 & 87 & hariṇa & 69 \\
\hline 32 & cațaka & 26 & 88 & musala & 61 \\
\hline 33 & kāka & 27 & 89 & dhruva & 56 \\
\hline 34 & tittira & 29 & 90 & kulālacakra & 98 \\
\hline 35 & baka & 30 & 91 & ușțra & 54 \\
\hline 36 & bhāradvāja & 28 & 92 & ākāśakapota & $*$ \\
\hline 37 & kukkuṭtoddāna & 88 & 93 & garuḍa & 39 \\
\hline 38 & araṇyacațaka & 89 & 94 & paroṣnị̄ & 63 \\
\hline 39 & mayūra & 32 & 95 & (unnamed) & 65 \\
\hline 40 & paṅgumayūra & 111 & 96 & bhāra & 99 \\
\hline 41 & khaḍga & 34 & 97 & nārada & 100 \\
\hline 42 & sūula & 40 & 98 & svarga & 101 \\
\hline 43 & viparītanṛtya & 90 & 99 & ūrṇanābhi & 49 \\
\hline 44 & śyena & 38 & 100 & śuka & 71 \\
\hline 45 & kapāla & 31 & 101 & tṛnajalāyukā & 60 \\
\hline 46 & sarpa & 42 & 102 & vṛnta & 72 \\
\hline 47 & (unnamed) & 114 & 103 & krauñca & 67 \\
\hline 48 & (unnamed) & 113 & 104 & varāha & 66 \\
\hline 49 & ardhapaścimatāna & 107 & 105 & matsyendra & 102 \\
\hline 50 & $\begin{array}{l}\text { ūrdhvapaści- } \\
\text { matāna }\end{array}$ & 108 & 106 & yoni & 103 \\
\hline 51 & (unnamed) & 109 & 107 & svastika & 59 \\
\hline 52 & baddhapadma & 33 & 108 & vajra & 68 \\
\hline
\end{tabular}




\section{(Continued)}

\begin{tabular}{|l|l|l|l|l|l|}
\hline No./HAP & Name & No./ŚTN & No./HAP & Name & No./ŚTN \\
\hline 53 & kukkuța & 36 & 109 & utkața & 104 \\
\hline 54 & pangukukkuța & 112 & 110 & śukti & 105 \\
\hline 55 & (unnamed) & 115 & 111 & śava & 70 \\
\hline 56 & chatra & 35 & 112 & tāna & $74^{84}$ \\
\hline
\end{tabular}

Table 5: Names of āsana-s in the Hațhäbhyāsapaddhati and in the Srittattvanidhi.

The order of the descriptions of the àsana-s in these texts is key to understanding how they are to be practised. In over a dozen instances, the description of one àsana relies on the description of the one directly before it. In other words, one must accomplish a "foundational" āsana, so to speak, in order to perform the next. Examples are gajāsana (26-31), cațakāsana (32-34), kukkuṭāsana (53-54, 58), etc. (see Appendix 2). The order of the āsana-s in the Hațābhyāsapaddhati is correct in so far as the description of each foundational āsana is placed before the one that depends on it. However, in the Śittattvanidhi, the āsana-s have been taken out of order, resulting in the foundational àsana-s being separated from those that depend on them. This means that one cannot understand many of the descriptions in the Śritattvanidhi without reading ahead. More importantly, it suggests that the section on àsana practice in the Hathābhyāsapaddhati is in all probability the source of those in the Sritattvanidhi because the latter has been compiled without retaining the correct textual order.

Furthermore, one would expect the Śitattvanidhi to have borrowed its material from elsewhere because it is a digest which is not specifically about yoga. In contrast to this, the Hatha äbhyāsapaddhati is undoubtedly a yoga text, and is more likely to be the source, unless this material derives from a third, earlier work that remains unknown. Sjoman's hypothesis ${ }^{85}$ that some of these āsana-s derive from Indian wrestling, gymnastics and so on, may still be true. However, the significance of the Hathābhyāsapaddhati is that it locates these àsana-s within Hatha Yoga. Therefore, there is now evidence that hathayogis practised dynamic àsana-s, some of which required the use of rope and walls, and such yogis may have played an important role in the development of these àsana-s.

Though it is beyond the scope of this chapter to discuss fully the significance of the Hathābhyāsapaddhati's àsana-s in the context of the historical development of Hatha Yoga, two observations can be made. The first striking feature is the inclusion of moving āsana-s. Many āsana-s are combined with a movement that is to be repeated over and over. Examples include vrṣapādakșepa (1), śvottāna (6), virata (20), luṭana (22), matsya (24), etc. (see Appendix 2).

84 This pose is called uttānapādāsana in the Śrittattvanidhi.

85 Sjoman 1999: $43 \mathrm{ff}$. 
The second feature, which is unique among medieval yoga texts, is that the àsana-s are arranged in six sequences, each with its own heading. The headings are as follows:

1. Supine āsana-s (uttānāni āsanāni)

2. Prone āsana-s (nubjāsanāni)

3. Stationary āsana-s (sthānāsanāni)

4. Standing āsana-s (utthānāsanāni)

5. Rope āsana-s (rajjvāsanāni)

6. āsana-s which pierce the sun and moon (sūryacandrabhedanāny āsanāni $)^{86}$

It appears as though these äsana-s have been sequenced according to how they were practised because, in some instances, the foundational āsana does not resemble the àsana being described. For example, the description of the ball posture (kandukāsana) stipulates that one should do the reed posture (vetrāsa$n a)$ beforehand. ${ }^{87}$ However, the reed pose, in which the spine is extended, does not resemble the ball pose, in which the spine is flexed. Therefore, the instruction of positioning oneself in the reed pose is not simply a literary device employed by the scribe to assist in describing the ball pose. Such an instruction is intended to indicate the sequence of practice. ${ }^{88}$

Furthermore, the headings and sequences suggest that the postures were developed in groups. These groups appear to be antecedents to the modern categories of standing, seated and floor poses, which are also combined in some styles to form sequences. ${ }^{89}$

Though the one available manuscript of the Hathābhyāsapaddhati appears to be incomplete and the text itself may be a truncation of an earlier work, it significantly extends our knowledge of Hatha Yoga in the eighteenth century. During this time, hathayogic āsana-s were adapted with a view to cultivating strength and fitness, through a comprehensive range of strenuous positions and continuous movements. Its section on àsana does not expatiate on the benefits of

86 These six headings correspond to äsana-s 1-22, 23-47, 48-74, 75-93, 94-103 and 104-122, respectively. Some of these headings are based on emendations. See Appendix 2. I do not know why there is a category called "piercing the sun and moon". The sun and moon are not mentioned in the descriptions of the äsana-s that follow this heading, and these poses do not suggest concepts of the sun and moon as left and right sides of the body, nasal dominance, prānāyāma, head and abdomen, etc.

87 The ball posture is àsana 18 in Appendix 2.

88 I would like to thank Dominic Goodall for bringing this to my attention.

89 Iyengar's subdividing of āsana-s into standing, sitting, supine, prone, etc., has been noted by Elizabeth De Michelis (2004: 234, n. 40). Swami Sivananda's book, Yoga Asanas (1993, first published 1931) is without subdivisions, though Swami Satyananda's book Asana Pranayama Mudra Bandha (1996, first published 1969) has subdivisions, including standing āsana-s. Other modern yoga books such as Shree Yogeshwaranand Paramahansa's First Steps to Higher Yoga (2001, first published 1970) present āsana-s in various groups. 
practising such àsana-s, other than to say they produce bodily strength (s'ārìradārdhya). Another manuscript of this text or, more ideally, the source from which it may have been extracted, will most probably provide more information.

\section{Chronology and Increments in the Number of Āsana-s in Medieval Yoga Texts}

All the texts and manuscripts containing extensive lists of àsana-s date to after the sixteenth century. The chronology of medieval yoga texts indicates a steady increase in the number of āsana-s practised in Hatha Yoga as it developed over time. A number of reasons seem probable here. Firstly, the increase may have resulted from competitive extension. In other words, one tradition tried to gain an advantage over another tradition by claiming to teach more àsana-s.

Secondly, if it ever comes to light that eighty-four āsana-s existed outside of Hatha Yoga before the fifteenth century, then it would appear that hathayogis gradually adopted them over the course of several centuries, despite their initial view that most of these àsana-s were superfluous. Hatha Yoga grew in popularity from the eleventh to the sixteenth centuries, as evinced by its transformation from an auxiliary practice in works such as the eleventh-century Kālacakratantra (Birch 2011:535-538) and the thirteenth-century Dattātreyayogaśāstra, in which it is one of four yogas, to a tradition of yoga in its own right as seen in the Hathapradipika. It is reasonable to assume that, by the end of the fifteenth century, Hatha Yoga must have been practised more widely and by a greater variety of people. Therefore, the growth in its popularity would have led to greater innovation, experimentation and the assimilation of practices from elsewhere, such as older traditions of asceticism and martial arts. This hypothesis is supported by the claim in some texts that Hatha Yoga was practised by people of different religions and social backgrounds in India. ${ }^{90}$

A third possible reason for the incremental growth in the number of āsana-s in yoga texts has more to do with the development of the literature rather than the yoga systems themselves. The early Hatha texts are short, pithy manuals that might have been written by and for practitioners. Over time, these yoga texts grew

90 For example, DYŚ 41-42ab: "Whether a Brahmin, renunciant, Buddhist, Jain, Kāpālika or follower of Cārvāka, the wise man who has confidence [in the efficacy of Hațha Yoga] and who is always devoted to the practice of [Hatha] yoga will attain all Siddhis" (brähmanah śramaṇo vāpi bauddho vāpy ārhato 'thavā | kāpāliko vā cārvākah śraddhayā sahitaḥ sudhīh $\| 41$ || yogābhyāsarato nityam sarvasiddhim avāpnuyāt). For statements suggesting that all four castes and women practised Hatha Yoga, see YY 6.12, 6.16-6.19ab and the Yogacintāmaṇi p. 57 (quoting without attribution Viṣnudharma 98.16). The Śivasamhitā (4.79, 5.258-260) taught Hațha Yoga for householders. 
in size and became more scholarly in their language and style. Hence, lists and descriptions of eighty-four postures may have manifested because later compilers were concerned more with thoroughness than brevity. Large scholarly compilations like the Yogacintāmaṇi were written for a more learned audience and tended to include more techniques from a greater variety of sources.

These three proposed reasons are not mutually exclusive and may have combined to produce the proliferation of assana-s seen in the later textual sources. Competitive extension and the growing popularity of Hatha Yoga suggest a gradual process of accretion. The gathering of sources and the creation of lists of eighty-four or more āsana-s was probably the most recent stage, which was the result of scholarly activity.

\section{Connections between Medieval and Modern Āsana-s}

In light of the fact that Indian yoga systems of the early twentieth century incorporated large numbers of äsana-s, it is worth asking if their pioneers were influenced by any of the unpublished texts discussed in this chapter. I know of no citation of these texts in a modern book on yoga, apart from Dr. M. L. Gharote's work, which cites the last two manuscripts. Gharote was a disciple of Swāmī Kuvalayānanda, who founded the Kaivalyadhama Yoga Institute with a view to popularising physical yoga throughout India from the 1920 s onwards. ${ }^{91}$ However, I am yet to ascertain whether Swāmī Kuvalayānanda knew of these yoga compendiums. The early publications of the Institute do not cite them.

Nonetheless, the citation of the sources I have discussed is not a necessary condition for proving their influence on gurus in the twentieth century. These sources indicate that over eighty-four āsana-s were known to hathayogis from several areas in north and south India before the British opened the floodgates to European modernity, ${ }^{92}$ and it is quite likely that knowledge of these $\bar{a}$ sana-s was

91 Alter 2004: 9, 86, 263, n. 22.

92 Various sources on the eighty-four āsana-s are ascribed to specific places. A scribal comment after the Hatharatnāvalì's first chapter colophon in a manuscript (no. 6715) held at the Tanjore Mahārāja Serfoji's Sarasvatī Mahāl Library, appears to identify the author, Śnīnivāsabhaț̣a, as native to Tîrabhukta ([...] pravartakatīrabhukte deśíya [...]) (For the complete transcript, see Sastri 1931: 4918). Venkata Reddy (1982: 14-15) opines that Śrīnivāsa may have belonged to a Tïrabhukta in Andhra Pradesh, but this name may also refer to the Videha country which is in northern Bihar (Sircar 1971: 101). In the Jogapradipyakā (v. 958), the author, Jayatarāma, says he was living in Vrindavan (i.e., near Mathura). Also, there are reports that libraries in Jodhpur and Jaipur hold several manuscripts which mention large numbers of āsana-s (e.g., the Āsananāmāni, Āsanayogagrantha, etc.; for details, see Gharote et al. 2006: lxiii). Also, eighty-four āsana-s are painted on the walls of the Mahāmandir in Jodhpur and one hundred miniatures are reportedly held at the Jaipur Central Museum 
transmitted to twentieth-century gurus not only by textual sources which are unknown to modern scholars, but by Brahmins who may have inherited the knowledge from their families or teachers. Pioneering yoga gurus, such as Krṣṇamācārya, Swāmī Kuvalayānanda and Shree Yogendra, were all Brahmins who disapproved of the extreme asceticism and Kāpālika practices of some renunciants. ${ }^{93}$ Therefore, it is more likely that they were influenced by the knowledge of Brahmins whose erudite forefathers had been appropriating Hatha Yoga since the seventeenth century, as evinced by texts such as the Yogacintāmani, the Hathasanketacandrikā and the so-called Yoga Upanișads. ${ }^{94}$

Generally speaking, most of the seated, forward, backward, twisting and armbalancing poses in modern yoga have been anticipated by these seventeenth and eighteenth-century sources. This may not be so apparent in comparing the names of āsana-s from one tradition to another, because similar āsana-s can have different names. ${ }^{95}$ This is true for both medieval and modern yoga. Such differences may reflect regional influences and attempts by gurus to distinguish their own repertoire of techniques. The main exceptions to this are the names of $\bar{a}$ sana-s in the well-known, principal texts such as the Pātañjalayogaśāstra and the Hathapradipikā. Since these texts have been invoked to establish the traditional credentials, so to speak, of more recent lineages, the names of their āsana-s have endured. ${ }^{96}$

As far as I am aware, the prominent modern practices of süryanamaskāra and vinyāsa are absent in medieval yoga texts. ${ }^{97}$ Though moving āsana-s and se-

(Gharote et al. 2006: lxvi). These indicate that eighty-four āsana-s were known in Rajasthan in the eighteenth and nineteenth centuries. A comment in the Hațhābhyāsapaddhati (fol. 26r) suggests the author was familiar with Maharashtra: "Similar to the Jāti sprout, the haritaśara by name is known in Mahārāștra, etc. as the Lavālā" ([...] jātyañkurasadṛso haritaśarah nāma lavālā iti mahārāșțāadau prasiddhaḥ \| Emend. jāty- : Codex jānty-. Emend. dŕśo : Codex drśa).

93 For more information on the disrepute of Hatha Yoga in the nineteenth and early twentieth century, see Singleton 2010: 78. He also mentions the yogis' association with mercenary fighters and the "risible contortions of the mendicant fakir". Such views are also seen in the work of Indologists at this time (Birch 2011: 529-530).

94 My comments here are confined to the gurus whose names I have mentioned. Also, Swami Sivananda of Rishikesh, who is said to have been initiated into the Daśnāmī sect in 1924 (Satyananda 1996: v), must have been a Brahmin because the Sarasvatî lineage initiates only Brahmins (Clark 2006: 39). Nonetheless, one cannot rule out that there were non-Brahmanical channels of transmission of other types of modern Indian yoga.

95 See Appendix 3 for examples of this.

96 There are also textual variations in the names of āsana-s transmitted in different versions of the PYŚ. See Maas' chapter in the present volume.

97 In his biography of his teacher Kṛ̣namācārya, A. G. Mohan (2010:29) defines vinyāsa and states his belief that vinyāsa was Kṛṣnamācārya's innovation: “A special feature of the asana system of Krishnamacharya was vinyasa. Many yoga students are no doubt familiar with this word - it is increasingly used now, often to describe the 'style' of a yoga class, as in 'hatha 
quences are described in the Hathābhyāsapaddhati, this text does not provide general guidelines on how the postures were practised. In fact, Sanskrit yoga texts do not stipulate whether a specific àsana was held for a long or short period of time or whether manipulating the breath was important. The absence of such details suggests that there was no consensus on these matters, which may have been left to each guru's discretion.

The prostration-like movements of sūryanamaskāra may derive from older devotional practices of sun worship but its inclusion as a technique in a system of yoga is without any known precedent until the twentieth century. In fact, the one reference to sūryanamaskāra in a medieval text on Hatha Yoga advises against its practice on the grounds that it might afflict the body (kāyakleśa) if performed many times. ${ }^{98}$ This comment indicates that a rather strenuous form of $s \bar{u} r-$ yanamaskāra was known in the nineteenth century, but descriptions of such a practice are yet to be found. ${ }^{99}$

Both late medieval and modern yoga make use of inverted āsana-s. In early Hațha Yoga, inversions are a mudrā called viparītakaraṇī. In late medieval sources, viparìtakaraṇi is included among descriptions of āsana-s with names

vinyasa' or 'vinyasa flow'. Vinyasa is essential, and probably unique, to Krishnamacharya's teachings. As far as I know, he was the first yoga master in the last century to introduce the idea. A vinyasa, in essence, consists of moving from one asana, or body position, to another, combining breathing with the movement."

98 In his commentary on the Hathapradīpika (1.61), the nineteenth-century Brahmānanda mentioned süryanamaskāra, but he did so only in the context of providing an example of a practice that, in his opinion, would afflict the body (kāyakleśa) if performed many times: “A method of afflicting the body is a method that causes affliction to the body. [It is] an action in the form of many sūryanamaskāra, etc. and lifting great weights, etc." (kāyakleśavidhim kāyakleśakaram vidhim kriyām bahusūryanamaskārādirūpām bahubhārodvahanādirūpāṃn $\mathrm{ca}$ ). The physical act of prostrating the body in worship is mentioned in some classical and early medieval Sanskrit sources. Examples include references to an eight-limbed prostration (aștāingapranāma), in which eight parts of the body touch the ground (aștāingapranipāta, asțängapranāma). See the following etexts available at muktabodha.org: Picumata/Brahmayāmala 45.375; Ciñcinīmatasārasamuccaya 8.38; Kulāranavatantra 17.98; etc. An aṣtāñgapraṇāma is described by Kṛ̣ṇ̄ānanda Āgamavāgīśa in his Bṛhattantrasāra 2.107-109. Chapter thirty-four of the Aṃśumatitantra is on "methods of prostration" (namaskāravidhi) and describes an eight-limbed prostration which destroys all diseases.

99 Polly O'Hanlon's article on "Military Sports and the History of the Martial Body in India" (2007: 511) refers to a letter written in 1759 by a trooper named Muzaffar Khan, who wrote to Nanasaheb Peshwa to inform him that a wound on his back was preventing him from practising his usual regime of danda and süryanamaskāra. Also, a more recent reference to a physically demanding type of süryanamaskāra can be found in A Short History of Aryan Medical Science by HH Sir Bhagvat Sinh Jee (1896: 61), who states, "There are various kinds of physical exercises, in-door and out-door. But some of the Hindoos set aside a portion of their daily worship for making salutations to the Sun by prostrations. This method of adoration affords them so much muscular activity that it takes to some extent the place of physical exercise." 
such as viparītakaraṇāsana, ${ }^{100}$ narakāsana, ${ }^{101}$ kapālāsana,${ }^{102}$ etc. There is some ambiguity in the descriptions of viparitakarani in early Hatha texts as to whether this mudrā has only the top of the head on the ground as headstand (śîr $r \grave{a} s a n a)$ in modern yoga or the back of the head and neck on the ground as shoulderstand (sarvāngāsana). ${ }^{103}$ The descriptions of inverted āsana-s in texts such as the Hațhäbhyāsapaddhati and the Jogapradīpyaka are clear in this regard: nara$k \bar{a} s \bar{a} n a$ and viparītakarañāsana are the equivalent of shoulderstand, and kapālāsana, headstand. ${ }^{104}$ Apart from viparitakaraṇi, there are several other instances of early hathayogic $m u d r \bar{a}$-s becoming āsana-s in late medieval sources; for example, mūlabandhāsana, ${ }^{105}$ mahāmudrāsana ${ }^{106}$ and yonimudrāsana. ${ }^{107}$ The deliberate application of hathayogic mudrā-s such as uddīyannabandha to seated $\bar{a} s a n a-s$ is a salient feature of Hatha Yoga ${ }^{108}$ However, the application of these mudrā-s in the practice of non-seated $\bar{a} s a n a-s$ is not mentioned in medieval sources and may be a modern development.

The extensive lists of āsana-s in medieval sources do not account for many of the standing poses in modern yoga. The similar shapes of these standing poses to exercises in European free-standing gymnastics and callisthenics is strong evidence for the influence of British physical culture on modern Indian yoga. ${ }^{109}$ However, very little is known of the fighting stances and lunges of medieval Indian wrestling and martial traditions, which may also have inspired some of modern yoga's standing poses. It is possible that Indian yoga gurus may have viewed callisthenic and martial postures as an extension of older standing äsana-s in texts such as the Hathāabhyāsapaddhati. Indeed, the ease with which these gurus integrated postures from outside yoga may well be the result of their knowledge of antecedents in earlier systems of Hatha Yoga. The standing poses of modern yoga are prominent in the styles emanating from Kṛșnamācārya, who was familiar with one hundred and eleven àsana-s of the Hathābhyāsapaddhati

100 JP vv. 163-165.

101 YC p. 157.

102 Hațhābhyāsapaddhati 45 (Appendix 2).

103 From the description of viparitakarañi in the Hathapradīpika (3.81), one might infer that it is a headstand because it is supposed to be held for three hours every day, which seems more practicable for headstand (see Bernard 1958: 29-31) than shoulderstand.

104 In the Yogacintāmaṇi (p. 157), narakāsana is headstand.

105 HSC, ms. no. R3239, fols. 34-35.

106 JP vv. 103-106.

107 JP vv. 107-109.

108 For examples, see the definitions of padmāsana and siddhāsana in the Hathapradīpikā $(1.35-36,44-46)$. These and similar definitions occur in both earlier and later sources on Hațha Yoga.

109 For the influence of physical culture on twentieth-century Indian yoga, see Singleton 2010. 
because he had read the Śritattvanidhi, which he cited in the introduction to his book called the Yogamakaranda. ${ }^{110}$

Kṛṣnamācārya's knowledge of the āsana-s in the Haṭhābhyāsapaddhati via the Śritattvanidhi raises the question of whether he knew their textual source(s). As mentioned above, the Hathābhyāsapaddhati appears to be an incomplete summary of another text, ${ }^{111}$ and the Śitattvanidhi is a compilation that must have borrowed its material on āsana practice from elsewhere. According to a biography ${ }^{112}$ and Singleton's interviews with Pattabhi Jois, ${ }^{113}$ some salient features of Kṛ̣ṇamācārya's teaching on āsana were derived from a Sanskrit yoga text called the Yoga Kurunta, which is also known to some of his students, including the Iyengars, Pattabhi Jois, Desikachar and his son, Kaustubh. ${ }^{114}$ Despite the prominence of the Yoga Kurunta in this lineage, no one has produced a copy of it. ${ }^{115}$ My research has not located a name similar to Yoga Kurunta in any catalogue of an Indian manuscript library.

Gītā Iyengar's book Yoga: A Gem for Women ${ }^{116}$ has a section entitled, "Āsana: Yoga Kurunța", in which she states that these āsana-s involve the use of a rope. In a more recent article, she reveals that the inspiration behind the rope poses was Krṣnamāāāya's knowledge of the Yoga Kurunța. ${ }^{117}$ The Haṭābhyāsapaddhati has rope poses, which indicates that ropes were used in this way in Hatha Yoga, possibly as early as the eighteenth century. None of the names of its rope poses correspond to those in Iyengar's book, but a connection between the $\mathrm{Ha}$ thābhyāsapaddhati and the Yoga Kurunța seems probable given that the former is the only extant yoga text in which rope poses have been described. One must wonder whether the name "Yogakurunța" was derived from Kapālakurantaka, the author of the Haṭābhyāsapaddhati. ${ }^{118}$ Moreover, Kṛ̣namāaārya's knowl-

110 Singleton 2010: 222, n. 7.

111 See n. 75.

112 Mohan 2010: 45.

113 Singleton 2010: 184-186.

114 Singleton (2010: 185) was told of Kaustubh's knowledge of this text in an interview.

115 According to the official website for the K. Pattabhi Jois Ashtanga Yoga Institute, Kṛṣnamācārya transcribed the Yoga Kurunța from a manuscript which may no longer be extant: "The method of Yoga taught at KPJAYI is that which has been told by the ancient Sage Vamana in his text called 'Yoga Korunta'. Although many books on Yoga have been written, Vamana is the only one who has delineated a complete practical method. In the 1920's, the Yogi and Sanskrit Scholar, T. Krishnamacharya traveled to Calcutta where he transcribed and recorded the Yoga Korunta, which was written on palm leaves and was in a bad state of decay, having been partially eaten by ants. Later, Krishnamacharya passed on these teachings to the late Pattabhi Jois, whose school continues to teach this method today" (http:// kpjayi.org/the-practice/traditional-method. Accessed 4 August 2014).

116 Iyengar 1998: 252.

117 The relevant passage of this article is cited in Smith 2008: 157, n. 5.

118 The name Yogakurantaka might be understood as the Yogayājñavalkya (i.e., "Yãjñavalkya on [the topic of] yoga"), but it might also be a play on the meaning of kuranțaka as "yellow 
edge of rope poses in the Yoga Kurunța and the reference to Kapālakurantaka in the Hathāabyāsapaddhati suggest a connection between these texts. It could be possible that Yogakurunța is another name for the Hațābhyāsapaddhati or the original work from which the incomplete manuscript of the Hathābhyāsapaddhati was extracted. Until the Yoga Kurunta is found, such hypotheses remain speculative, particularly in light of the inconsistencies in statements made about the contents of the Yoga Kurunța by various students within Kṛ̣nnamācārya's lineage, as Singleton has noted: ${ }^{119}$

Krishnamacharya's grandson, Kausthub Desikachar, refers to writings by his grandfather that "contradict the popularly held notion that the Yoga Kuranta [sic] was the basis for Astanga Vinyasa Yoga" (Desikachar 2005: 60). Since nobody has seen this text, such statements can be more profitably interpreted as an indication that the "content" of the work changed as Krishnamacharya's teaching changed (and perhaps also as another symptom of the struggles to manage the memory and heritage of Krishnamacharya). That is to say, during his time in Mysore with Pattabhi Jois, Krishnamacharya may have invoked the text to legitimize the sequences that became Ashtanga yoga, but in later life he used it to authorize a wider set of practices.

\section{Conclusion}

The manuscript evidence discussed in this paper will contribute toward a more nuanced history of āsana practice. Though the corpus of early Hatha Yoga contains relatively few äsana-s, it is becoming clear as more textual evidence is found that after the sixteenth century Hatha Yoga traditions gradually incorporated larger numbers of àsana-s to the point that some mention and describe more than eighty-four. The aggregate number of $\bar{a} s a n a-s$ in these late medieval sources is at least several hundred in addition to the dozen or so standard āsana-s which are found in earlier yoga texts.

Further research is required to determine the degree to which medieval àsana-s correspond to those taught in India in the modern period. As I mentioned above, it seems that certain types of āsana-s correspond whereas others do not. However, it is often very difficult to compare medieval and modern āsana-s because of the ambiguities and omissions in the Sanskrit descriptions of the former, the number of variations of the latter and the different names for the same àsana in both medieval and modern traditions. For example, as outlined in Appendix 3, a basic comparison between Pattabhi Jois' primary sequence of

amaranth" (Monier-Williams 1899, s. v.). One might understand Yogakurantaka as the "yellow amaranth of yoga", much like the title Hathayogamañjari.

119 Singleton 2010: 185. Singleton's reference is to Desikachar's book The Yoga of the Yogi: The Legacy of T. Krishnamacharya (Chennai: Krishnamacharya Yoga Mandiram). 
assana-s and the sources consulted for this paper suggests that his floor and finishing poses are the types of modern āsana-s most similar to medieval ones. However, apart from iconic äsana-s such as padmāsana, few modern and medieval äsana-s have the same names or correspond in every detail.

Owing to the absence of citations of premodern texts that describe large numbers of $\bar{a} s a n a-s$, such as the Hatharatnāvalì, Jogapradīpyakā and Hathāabhyāsapaddhati, in twentieth-century yoga books, such as Jois' Yogamālā, it is not possible to evaluate their influence on modern yoga in any definitive way. Nonetheless, these pre-modern works are important for reconstructing the history of yoga because their content indicates that Hatha Yoga continued to evolve in the seventeenth and eighteenth centuries. During this time, the number and sophistication of its techniques grew not only in àsana practice, but also in the practice of șatkarma, prānāyāma and mudrā. Furthermore, some of these texts evince the integration of hathayogic teachings with mainstream Brahmanical traditions, which increases the likelihood that those Brahmins who taught physical yoga in the twentieth century knew of these relatively recent developments in Hațha Yoga.

\section{Appendix 1: Descriptions of the Additional Āsana-s in the Ujjain Manuscript}

The following is a diplomatic transcription of the descriptions of äsana-s which appear in list $1 \mathrm{~b}$ of the above chapter. These āsana-s and their descriptions do not occur in other manuscripts of the Yogacintämani and, apart from those few which are based on Vācaspatimiśra's Tattvavaiśäradī and three others which I have indicated in the footnotes, I am yet to find the majority of these descriptions in another text or manuscript. I have suggested some conjectures and emendations in the footnotes, and hope that this transcription may contribute to the critical editing of these descriptions. I have reproduced the numbering of these $\bar{a} s a n a-s$ in the Ujjain manuscript. The gaps in the numbering are those àsana-s in list 1a, descriptions of which occur in the edition and other manuscripts of the Yogacintāmaṇi. 
[fol. 59r]

1. kevalasvastikam [||] jānūrvor antare samyak kṛtvā pādatale ubhe \| rijukāyah samāsīnah svastikam tat pracakṣate $\|^{120}$ anyac cāgre śīvanyā ātmana ityādi uttaraprsțhe [l|]

3. ardhāsanam ${ }^{121}[\|]$ ekapādam athaikasmin vinyasyoruṇi sattamah \| āsītārdhāsanam idam yogasādhanam uttamam \|

$8{ }^{122}$ paryañkāsanam uktam yogabhāṣyatịikāyāṃ vācaspatinā || jānuprasāritabāhvoh paryañka ${ }^{123}$ iti $\|$ tattvam tu paprāsanah ${ }^{124}$ [||] bhūmau śayitvopajānuhastadvayam sthāpayet [II] tena catur sayakapādavad asya ${ }^{125}$ jānudvayaskandhadvayarūpam catuṣkaṃ bhātīiti || 2 madīyạ̣ $\|^{126}$

\section{[fol. 59v]}

[no number] ${ }^{127}$ yathā vācyatyasyatalayor ${ }^{128}$ ardhasamsparśād uccajanghayoh [||] pādayor jānudeśe vai vīrākhyam yogapaț̣atah || iti vīrāsanalakṣaṇāntaram [||]

20. garuḍāsanam [no description]

[fol. 60r]

28. markațaṃ [||] śavāsanasthau dvau pādau bhūmau mastakato [']nyatah [|] kuryād utthāya vegenādhasthitir markațam ${ }^{129}$ tu tat $\|$

29. garbhāsanaṃ [||] garbhāsane nirañjanakriyā tallakṣaṇaṃ tu \|

120 This is the same as svastikāsana in HP 1.21. The quotation following this (i.e., sizvanyā $\bar{a} t m a n a)$ refers to the description of svastikāsana in the Yogayājñavalkya (3.4-5ab), which is quoted on a subsequent page of this manuscript (i.e., as āsana no. 14).

121 This is the same as the description of ardhäsana in other manuscripts of the Yogacintämani.

122 The following descriptions of paryankāsana are a marginal note in the lower margin of this folio (i.e., 59r).

123 One might consider the diagnostic conjecture śayanam paryañka iti.

124 Consider padmāsanah for paprāsanah.

125 Consider paryainkavad asya for sayakavad asya. I wish to thank James Mallinson for this suggestion.

126 The first description of paryañkāsana is based on that in Vācaspatimiśra's Tattvavaiśâradī. I have not found the second description in another yoga text.

127 The following description of viransana is a marginal note at the top of the folio.

128 Consider vā vyatyasya for vācyatyasya.

129 There are two numbers written as a fraction which divide this word in the Codex: marka 16/ 100 tam. This is a reference to the word caturaśit i, which is in the line above. 
[fol. 61v]

34. cakrāsanaṃ [|l] śavāsanasthau dvau pādau kuryān mastakatah pari ${ }^{130} \|$ vyutkramena tataḥ śīghram etat sarvasya sādhana[m] || sarvāsananidānaṃ ${ }^{131}$ gulmaplīhāvātarogādināśanam $\|^{132}$

35. daṇ̣̂āsanam [||] upaśliṣyāngulikau ${ }^{133}$ bhūmiśliștajañghorupādau prasārya daṇ̣āsanam abhyased iti \|

36. sopāśrayaṃ [||] yogapatṭayogād idam evaṃ sopāśrayaṃ iti vācaspatih ||

37. candrāsanaṃ [||] vāmaṃ vā dakṣiṇaṃ vāpi pādapārśvam bhuvi nyaset || gulphe $^{134}$ tatrānyad āsthāpya saṃsthārdhenduprakīrtitam ${ }^{135} \|$

38. krauñcaniṣadanaṃ [||] krauñcah pakșiviśeșaḥ tadvat yathā [||]

39. hastinah [||] hastina iva sthitih yathā [||]

40. ușțrasya [|l] pādadvayatala ${ }^{136}$ nitambau dhṛtvā karo talopari ${ }^{137}$ karatalam yuktạ̣ lingāgre 'thavā muṣthidvaye ${ }^{138}$ mastakam $^{139}$ vā kṛtvoșțrasya sthitis tad āsanaṃ || nādaṃ śṛ̣uyāt ||

41. samasaṃsthānam [||] pārṣṇyāgrapādābhyāṃ ${ }^{140}$ dvayor ākuñcitayor anyonyapị̣̂anaṃ yenāvasthitasya sthairyam sukhạ̣ ca jāyate sthirasukham āsanam iti yogasūtrāt ||

[fol. 62r]

42. bhagāsanaṃ [||] pādadvayasya pārṣṇyāgre lingabhūmyor ${ }^{141}$ dṛ̣haṃ nyaset || śanair utthāya hastābhyāṃ dhṛtvā bhūmiṃ tatah punaḥ pādāgre prṣ̣thataḥ kṛtvā

130 Consider parau for pari.

131 Consider -nidhānam for -nidānam.

132 This āsana is described in Nārāyanatīrtha's Yogasiddhāntacandrikā in the commentary on sūtra 2.46.

133 Correct upaślișāñgulikau to upaśliștāingulikau.

134 Consider gulpham for gulphe.

135 Correct samsthārdhendu to saṃsthärdhendum.

136 Consider -tale for -tala.

137 Consider karatalopari for karo talopari.

138 Correct mușthi- to muști-.

139 Consider mastake for mastakam.

140 Consider pārșnyagra for pārș̣yāgra.

141 Consider lingam bhūmyām for lingabhūmyor. 
yuktau pārṣnī puras tatạ̣ || pādayoḥ pṛsṭhapārśve tu gudaṃ saṃsthāpya cāgrataḥ upasthapārśvayor ${ }^{142}$ gulphau yat saṃsthāpyau bhagam tu tat || phalam [||]

43. kubjāsanam [ [||] vāmapādatalaṃ dakṣahastenākṛsya vai balāt || vāmakakṣāṃ nyased dakṣaṃ dakṣakakṣe yathāvidhi \| tattatpārṣnẹer adhobhāge tattad +ūrparakāgratah ${ }^{143}$ dhārayet tiryagāsthānaṃ kubjāsanam idam bhavet ||

44. naḍāsanam [||] mohanadāsenokte | prathamaṃ jānudvaye sthitvā vāmakaramuștịm baddhvā dakṣinajātuni ${ }^{144}$ saṃsthāpya dakșinajānun ${ }^{145}$ kim api sammmardhya ${ }^{146}$ dhārayet tena hastadvayam api bandhadvayaikībhūtena ${ }^{147}$ nābhiṃ saṃmardayitvātrāntare [']dhaḥsthitapārṣnibhyāṃ nitambau sammmardhyaa $^{148}$ gudam ākuñcyāgrim ${ }^{149}$ ūrdhvagataṃ kṛtvā līno bhaved iti \| etenāghanāśạ̣ alakṣyaprakāśạ̣ \|

45. garbhāsanaṃ [||] garbhasaṃsthānaṃ yathā tathā tat || tatra nirañjanakriyā kartavyā || so [']ham ityādeh japah \|

46. vūlyāsanam ${ }^{150}[\|]$ ubhayapārṇiyugam ${ }^{151}$ jānvor ādhāya kațiprșṭthe same kṛtvā hastena nābhim utthāpya duttanyādbalena ${ }^{152}$ gurudarśitena iḍāpingale badhnīyāt yāvat granthidvayaṃ sthiraṃ patati tadā nānā sukhāni yatra tan naulīkarmopayuktam iti [||] ke cit tūtthāya jānudvaye hastadvayam sthāpya tathā sthitvā jānudvaye kūrparadvayam hastadvayena śankhadvayam avalambya balena naulīm kurvanti \|

47. stambhāsanaṃ [||] nyubjaḥ jaṅghāmadhye karadvayaṃ kṛtvā karau bhūmau kṛtvāntarikṣo bhaved oṃkāram raṭhed ${ }^{153}$ iti $\|$ pṛthvīnīrāṃśanāśạ̣ phalam ||

[fol. 62v]

48. śūnyāsanaṃ [||] karadvayamuṣtị baddhvā tatah pṛthivyāṃ saṃsthāpyānta-

142 After upasthapārśvayor, there is a mark pointing to a definition of upastha, which has been written at the top of the folio: upastham vaksyamannayor bhagalingayor ity amarah.

143 Consider tattatkūrparakägratah for tattad+ürparakägratah.

144 Correct dakșinajātuni to dakșinajānuni.

145 Correct -jānunī to -jānuni.

146 Correct sammardhya to sammardya.

147 Consider bandhayitvaikībhütena for bandhadvayaikībhūtena.

148 Correct sammardhya to sammardya.

149 Consider àkuñcyāgnim for ākuñcyāgrim.

150 The word $v \bar{u} l y \bar{a}$ sanam is the result of a correction and the original reading is likely to have been nyubjāsana. The $k a$ has been written over another ligature.

151 Correct ubhayapārṇiyugam to ubhayapārśniyugam .

152 The ligatures $-y \bar{a} d b a$ - are not clear. Consider tüttanyād balena for duttanyädbalena.

153 Correct rathed to rated. 
rikṣam utthāpyālakṣyaṃ ${ }^{154}$ rațed iti || vāmacaraṇānguṣthaṃ gṛhītvā vāmakūrpare $^{155}$ bhāraṃ dadyāt || iti || dvi+unīi ${ }^{156}$ [||]

49. haṃsāsanaṃ [||] prṣṭhaśīrṣakaṭị̣ kṛtvā samāḥ jan̉ghāṃ tu jan̉ghikāṃ madhye saṃsthāpya vyatyasya pārṣnị jānvor adhaḥ sthitau hastāgrābhyāṃ samākuñcya haṃsam jāpī ca haṃsake \| hamsa so [']haṃ $\|^{157}$

[fol. 67r]

|| lakṣmaṇadāsasvara yogī ||

50. gaṇeśāsanaṃ [||] gomukhe saṃsthitiṃ kṛtvā pārṣṇī vyatyasya yugmake \|| tatra sīvanikāṃ sthāpya gaṇeśāsanam īritam [||] ālasyanidrākṣayam [||]

51. gudāsanaṃ [||] pādayoh pṛșțhake cobhe vyatyasya bhuvi saṃsthite || gudaṃ madhye tu saṃsthāpya gudāsanam iti smṛtam $\|^{158}$

52. pārvatyāsanaṃ [||] dvau pādau melayitvā tu gudāgre ca pṛthak nyaset | bhūmau tadurdhvaṃ ca karau saṃpuṭau sthāpayet tatạ̣ || dakṣiṇānāmikāmadhye lingavad ūrdhvam ānayet | tatra dṛṣtị̣ sthirāṃ kṛtvā prakāśo hṛdi jāyate ||

53. āsāvarī [||] madhyadaṇḍam tiryagvyastagātraṃ kāṣthaṃ ca yogināṃ | āsāvarīti vikhyātam āsanālambi tad viduh [||]

54. nidrāharam [||] kṛtapadmāsano yogī tidvai ${ }^{159}$ jānuparvaṇi ${ }^{160}$ || āsāṃ ca svodare lagnāṃ kṛtvā saṃpuṭitau karau || muṣṭikrṭtau yojayet tu tarjanyau saṃprasāritau || ūrdhvạ̣ vā nāsikāgram lokayen mīlitekṣaṇạ̣ madhukamūlikānasyaṃ ${ }^{161}$ nasi kșiptā ${ }^{-162}$ nidrā naśyati $\|$ yathā $\|$

154 Above alaksyam, there is a small mark with the symbol of om written next to it.

155 There is a marginal note above the word kürpare but its first ligature is illegible to me: + ihuni.

156 This marginal note, which is very difficult to read, might be indicating that the position of the left foot and elbow should also be done on the right side.

157 There is a comment following the description of hamsāsana: anante vā samäpattir āsanam nirvartayatīti | anante nāganāyake sahasraphanavidhṛtadharāmaṇdale $\|$. This comment appears to be derived from Vācaspatimiśra's commentary on Yogasūtra 2.47, and has little to do with hamsāsana.

158 Following the description of gudasana, there is a gap and then, in small and faint writing, what appears to be an interlinear comment: bhāgāsanam tūktam.

159 Consider tisthed vai for tidvai.

160 Correct jānuparvan̄i to jānuparvani $i$.

161 Correct madhuka- to mādhuka-. Below the description of nidrāhara there is the following comment: śunțhāmarīcapippalī $\|$ samabhāgacūrṇa[m] nasiprotạ̣ san nidrābhañgi $\|$.

162 Consider kșiptam for kșiptā. 


\title{
Appendix 2: One Hundred and twelve Descriptions of Āsana-s in the Hațhābhyāsapaddhati ${ }^{163}$
}

\author{
Now, the Supine Poses.
} athottānāni āsanāni

1. Having lain supinely, [the yogi] should bind the neck with the fingers, join the elbows, touch the buttocks on the ground, extend one leg and rotate [separately] the other leg to the left and right. [This] is "pawing the leg like a bull" [pose].

uttānam śayanam krtvā àngulibhị kandharām baddhvā kūrparau militvā ${ }^{164}$ nitambena bhūmim sprșțvā ekaṃ pādam prasārya ekaikena pādena savyadakșinamạ bhrāmayet ${ }^{165}$ vrṣapādakṣepam bhavati || 1 ||

2. Having lain supinely, [the yogi] should join and extend the legs, touch the buttocks on the ground, clasp the neck with the hands and hold the breath and remain thus. [This] is the iron-bar pose.

uttānam śayanam kṛtvā pādau militvā prasārya nitambam bhūmau sprșțiā hastābhyām ${ }^{166}$ kandharāṃ baddhvā kumbhakam ${ }^{167}$ krtvā tiṣthet parighāsanam bhavati || 2 ||

3. Lying supinely and having placed both elbows on the navel, [the yogi] should extend one hand at a time and hold the nose by the thumb, with the gaze on it, while supporting [the position] with the region of the hips. He should remain thus. [This] is the hatchet pose.

[fol. 3r] uttānaśayanam kūrparadvayam ${ }^{168}$ nābhau sthāpayitvā ekaikam hastam prasārya nāsikāyām añguṣthapradeśena ${ }^{169}$ dhṛtvā tallakṣyeṇa jaghanapradeśena dhṛtvā sthāpayet paraśvāsanam bhavati || 3 ||

4. Lying supinely and having fixed one foot on [the back of] the neck, [the yogi] should grasp the toes of [that] foot with the other hand, lengthen the other foot

163 The scribe of the manuscript has not applied the sandhi rules between two words that end and begin with vowels. I have retained this peculiarity in my edition. When this occurs between two words in a compound, I have indicated that this is a compound by linking the two words with an n-dash between square brackets (i.e., [-]).

164 Emend. militvā : Codex mīlitvā.

165 Emend bhrāmayet: Codex bhrāmayitvā.

166 Emend. hastābhyām : Codex hāstābhyām.

167 Emend. kumbhakam : Codex vumbhakam.

168 Emend. kūrparadvayam : Codex kūparadvayam.

169 Emend. anguștha- : Codex agușța-. 
and hand and remain thus. [He should then do the other side. ${ }^{170}$ This] is Ananta's pose.

uttānaśayanam ekaikaṃ pādam grīiāyām vinyasya itarahastena pādāgram gṛhītvā itarapādahastau lambīkrtya tișthet anantāsanam bhavati \|| $4 \|$

5. [The yogi] should lie supinely. Putting one foot on the [back of the] neck, he should place the other hand on the root of the ear. Having placed the elbow of this arm on the ground, while making the other hand and leg straight, he should remain thus [and then do the other side. ${ }^{171}$ This] is the goad pose.

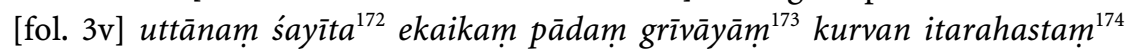
karnamūle sthāpayet tasyaiva hastasya kūrparam ${ }^{175}$ bhūmau nidhāya itarahastapādau saralīkrtya ${ }^{176}$ tișthet añkuśāsanam ${ }^{177}$ bhavati $\|5\|$

6. Having placed the body [supinely] like a corpse, [the yogi] should join the knees together, bring [them] onto the navel, clasp the neck with the hands and rotate [the legs. This is] the up-turned dog [pose].

śavavac charīram saṃsthāpya jānunī sammmīlya nābhau ānīya ${ }^{178}$ hastābhyām kandharā $\underline{m}^{179}$ baddhvā bhrāmayet śvottānam bhavati $\|6\|^{180}$

7. Having positioned [himself] as in the up-turned dog [pose, the yogi] should touch both knees with his ears in turn. [This is] the up-turned cat [pose].

[fol. $4 \mathrm{r}$ ] śvottānavat samsthitim ${ }^{181}$ krtvā jānudvayam paryāyena karnayoh samsprọset mārjārottānam ${ }^{182}$ bhavati $\|7\|$

8. Then, having lain supinely and holding the earth with the soles of the feet, [the yogi] should stand up. [This] is the wolf pose.

atha uttānam śayanaṃ kṛtvā pādatalābhyāṃ bhūmim dhṛtvā uttișthet vṛkāsanam bhavati || 8 ||

170 This is indicated by the use of ekaikam.

171 This is indicated by the use of ekaikam.

172 Emend. śayìta: Codex śạ yìta.

173 Emend. Preisendanz grīvāyām : Codex grivāyām.

174 Emend. -hastam : Codex hatam.

175 Emend. kürparam : Codex küparam.

176 Emend. sarali- : Codex sarali-.

177 Emend. an்kuśásanam : Codex añkuśāsana.

178 Emend. ānìya: Codex amnìya.

179 Emend. kandharām : Codex kadhārām.

180 At the bottom of this folio (3v) there is a marginal note: dattātreyo gurur jayati $\|$.

181 Emend. śvottānavat samsthitim : Codex śvottānava samsthiti.

182 Conj. mārjārottānam : Codex mārottānaṃ. 
9. Lying supinely, gripping the ground with the soles of both feet, [the yogi] should put the elbows on the ground and should raise up his back [from the ground. This] is the mount Trikūta [pose].

uttānaśayanam pādatalābhyām bhūmim dhṛtvā kūrparau avanau nidhāya prșţhadeśam ürdhvam unnamayet trikūtam bhavati || $9 \|$

10. Lying supinely, [the yogi] should place the soles of the feet on the up-turned hands and raise the back part of the body from the ground. This] is the monkey's seat.

uttānaśayanaṃ pādatale uttānahastayoh sthāpayet prșțhabhāgaṃ unnamayet markațapițhạ̣ bhavati || 10 ||

11. Lying supinely and having supported [himself] with both elbows on the ground and the hands on the buttocks, [the yogi] should hold his head, thighs, shanks and feet [straight] like a stick. [This] is the boat pose.

[fol. 4v] uttānaśayanam kūrparābhyām bhūmim avaștabhya hastau nitambe nidhāya śirah[-] ūrujanghhāpādān daṇdavat dhārayet naukāsanam bhavati $\|11\|$

12. Having positioned [himself] like the boat, [the yogi] should take the toes of both feet upwards. This is the horizontal boat pose.

naukāvat ${ }^{183}$ sthitvā ūrdhvam pādāgradvayam nayet tiryainnaukāsanam bhava$t i\|12\|$

13. [Having positioned himself] like the horizontal boat and supporting [himself] with the neck, back and elbows on the ground, [the yogi] should take up the toes of both feet, pointing [them] toward the head. [This] is the banner pose. [fol. 5r] tiryañnaukāvat grīvāprșthakūrparaih bhümim avaștabhya mastakalakṣena pādāgradvayam ūrdhvam nayet dhvajāsanam ${ }^{184}$ bhavati $\| 13$ ||

14. Having planted [firmly] the nape of the neck on the ground, [the yogi] should raise up the toes of both feet. [This] is the pose from hell.

grīvākanțhena bhümim viștabhya pādāgradvayam ürdhvam unnayet narakāsanam bhavati || $14 \|$

15. Having remained in the pose from hell, [the yogi] should place the upper side of the feet on the ground near to the region of the nose and join both hands. [He] should make [the arms] long and "plough" the ground with the neck. [This] is the

183 Emend. naukāvat: Codex naukāva.

184 Emend. dhvajāsanam : Codex dhvajāsana. 
plough pose.

[fol. 5v] narakāsane sthitvā ānāsikapradeśe ${ }^{185}$ bhūmau pādaprșțe sthāpya hastadvayam sammmīlya lambīkuryāt ${ }^{186}$ grīvapradeśena bhūmim karșayet lāingalāsanam bhavet || 15 ||

16. Lying supinely and having placed the palms of both hands and the soles of both feet on the ground, [the yogi] should raise up the region of the navel. [This] is the sofa pose.

uttānaśayanam hastatalābhyām bhūmim avaștabhya pādatalābhyām bhūmim dhṛtvā nābhipradeśam ūrdhvaṃ kuryāt paryaìkāsanam bhavati || 16 ||

17. Having remained in the sofa pose, [the yogi] should join his hands and feet. [This] is the cane pose.

[fol. 6r] paryaìkāsane sthitvā hastapādau saṃmīlayet vetrāsanaṃ bhavati || 17 ||

18. Having remained in the cane pose and pulling his hands and feet apart, [the yogi] should take [them] upwards and press the ground with his backbone. [This] is the ball pose.

vetrāsane sthitvā hastapādān niṣkṛsya[-] $m^{187}$ ürdhvam nayet prșṭthavamśena ${ }^{188}$ bhūmim pīdayet ${ }^{189}$ kandukāsanam bhavati || 18 ||

19. Having placed one foot on one thigh and the other foot on the other thigh, [this] is the lotus pose. Having threaded the hands in between the thighs and knees, [the yogi] should clasp the neck [with the hands and remain up-turned. [This] is the up-turned turtle [pose].

ekasmin ūruṇi ekaṃ pādam krtvā anyasmin ūruni anyam pādam kṛtvā padmāsanaṃ bhavati [|] ūrujānvor antarayoh hastau praveśya ${ }^{190}$ kandarām baddhvā uttānam tiṣthet uttānakūrmam bhavati \| 19 \|

20. Having placed the shanks and back on the ground and positioning the thighs on the calves, [the yogi] should touch his backbone [on the ground] again and again. [This] is the pose for one who has ceased [from worldly activities].

185 Conj. [Dominic Goodall] ānāsika- : Codex nāsikā-.

186 Emend. sammīlya lambī-: Codex samìlya lambi-.

187 Emend. niskrssyam : Codex niṣksyam. The final consonant appears to have been inserted to separate the preceding vowel from the following one.

188 Emend. prșțhavamśena: Codex prāsțhavamśena.

189 Diagnostic Conj. [Dominic Goodall] pìdayet : Codex pothayet.

190 Emend. praveśya: Codex praviśya. 
janghāprșțhe ${ }^{191}$ bhūmau nidhāya janghodarayoh ūruṇi ${ }^{192}$ samsthāpya prșthavaṃśam ${ }^{193}$ vāram vāraṃ sprśsyet ${ }^{194}$ viratāsanam bhavati $\| 20$ \|

21. Lying supinely, supporting the knees on [the region of] the heart and binding the hands on the thighs and shanks, [the yogi] should rock to the left and right. [This] is the stone pose.

[fol. 6v] uttānaśayanam jānunī hṛdaye 'vaștabhya jañghāsahita[-]ūruṇi karadvaye baddhvā savyāpasavyam lodayet dṛ̦adāsanam bhavati || 21 ||

22. Lying supinely, [the yogi] should pass the feet over the head, place them on the ground and lie prone. Having lain pronely, [the yogi] should place his back on the ground and do [this rolling movement] again and again, successively. [This] is the rolling pose.

uttānaśayanam pādau śira ullañghya bhūmau sthāpayitvāa ${ }^{195}$ nyubjam bhūyate ${ }^{196}$ [l] nyubjam śayanam pṛ̦țhe ${ }^{197}$ bhūmau nidhāya punah punaḥ paryāyeṇa ${ }^{198}$ kartavyam $^{199}$ luṭanāsanam ${ }^{200}$ bhavati || 22 \|

Now, the Prone Poses.

[fol. 7r] atha nyubjāsanāni ${ }^{201}$

23. Having lain pronely, placing the navel on the ground and supporting [himself on] the ground with the forearms like pillars, [the yogi] should join the lips, make the [sound] "sū" like a flute and remain thus. [This] is the lizard pose.

nyubjaśayanam kṛtvā nābhim bhūmau nidhāya stambhavat hastābhyām ${ }^{202}$ bhümim avaștabhya oṣthau nimīlya ${ }^{203}$ venuvat sūkrtya tișthet sarațāsanam bhavati || $23 \|$

191 Emend. jainghāprșthe : Codex janghāprssththi.

192 Emend. ūruṇi : Codex ürunii.

193 Emend. prștha- : Codex prsțthi-.

194 Emend. sprśsyet: Codex spryet.

195 Emend. sthāpayitvā : Codex sthāpayitvya.

196 Emend. bhüyate : Codex bhüyati.

197 Emend. prsțthe : Codex prștham.

198 Emend. paryāyena: Codex payāyeña.

199 Emend. kartavyam : Codex katavyam.

200 Emend. luthanāsanam : Codex luțanāsanam.

201 Emend. atha nyubjāsanāni : Codex anyubjāsanāni.

202 Conj. stambhavat hastābhyām : Codex stamvatstābhyāṃ.

203 Emend. nimīlya: Codex nimilya. 
24. Lying pronely and having raised up the elbows by the sides [of the body, the yogi] should support [himself on] the ground with the palms of both hands and fly up again and again. [This] is the fish pose.

nyubjam śayanam kūrparau pārśvabhāgābhyām ūrdhvīkrtya ${ }^{204}$ hastatalābhyām bhūmim avaștabhya vāraṃ vāraṃ uḍ̂̄ānaṃ kuryāt matsyāsanam bhavati || 24 ||

25. [Lying] pronely, [the yogi] should put the toes on the ground, keep [the legs] long, place the palms of both hands at the top of the head and raise up the buttocks. Gazing at the navel and taking the nose onto the ground, [the yogi] should take [the nose forward] as far as the palms of his hands. He should do thus again and again. [This] is the elephant pose.

[fol. 7v] nyubjam pādāgre bhūmau kṛtvā lambībhūya mastakāgre hastatalau nidhāya nitambam ūrdhvam unnamayya nābhiṃ ${ }^{205}$ lakṣya bhūmau nāsikām $\bar{a} n \bar{y} y a^{206}$ hastatalaparyantam ${ }^{207}$ nayet ittham punah punah kuryāt gajāsanaṃ bhavati || 25 ||

26. Remaining as in the elephant pose, [the yogi] should take his head to the right armpit, [and then] to the left armpit, again and again. ${ }^{208}$ [This] is the hyena pose. gajāsanavat $^{209}$ sthitvā mastakam vāram vāram dakṣinakukṣim savyakukṣim nayet tarakṣvāsanam bhavati || 26 ||

27. Having bent one leg at a time, [the yogi] should do the elephant pose. [This] is the bear pose.

ekaikaṃ pādam ākuñcya gajāsanam kuryāt ṛkṣāsanam bhavati || 27 ||

28. In the position of the elephant pose, [the yogi] should bend both knees and repeat it again and again. [This] is the hare pose.

[fol. 8r] gajāsanasaṃsthitau jānudvayam ākuñcya vāram vāraṃ kartavyam śaśāsanaṃ bhavati || 28 ||

29. In the position of the elephant pose, [the yogi] should rotate one leg at a time anteriorly and continue to do thus. [This] is the chariot pose.

204 Emend. ürdhvīkrtya: Codex urdhvikrtya.

205 Emend. nābhim : Codex nābhi.

206 Emend. ānìya : Codex āniya.

207 Emend. hastatalaparyantam : Codex hastatalāparyantam.

208 The practicalities of this pose suggest that the author is using the word kukși to refer to the armpit. This is supported by the use of this same word in the description of the ucchiss $a$ kāsana (no. 65), in which kukși clearly means the armpit.

209 Emend. gajāsanavat: Codex gajāsanava. 
gajāsanasaṃsthitau ekaikaṃ pādaṃ purobhāgena bhrāmayitvā kartavyaṃ rathäsanam bhavati || 29 ||

30. In the position of the elephant pose, [the yogi] should ram the ground with one arm at a time. [This] is the ram pose.

gajāsanasaṃsthitau ekaikaṃ bāhuṃ bhūmau tā ḍayet meṣāsanaṃ bhavati || 30 ||

31. In the position of the elephant pose, having raised both legs into space, [the yogi] should touch the ground with the head. [This] is the goat pose.

gajāsanasamsthitau pādadvayam antarālekṛtya mastakena bhūmim spṛset ajāsanam bhavati || 31 ||

32. Having supported [himself] with the forearms on the ground and bending the knees into the navel, [the yogi] should remain thus. [This] is the sparrow pose. [fol. 8v] kürparaparyantau hastau dharām avaștabhya jānunī nābhau samkuñcya tișthet catakāsanam bhavati || 32 ||

33. Having positioned [himself] on the hands like the sparrow pose, [the yogi] should touch the ears with the knees, place both shanks on the [upper] arms and remain thus. [This] is the crow pose.

hastau cațakāsanavat saṃsthāpya jānudvayam karṇau samspṛ́sya janghādvayam $^{210}$ bāhvor nidhāya tiṣthet kākāsanam bhavati || 33 ||

34. In a position like the crow pose, [the yogi] should join the shanks on [each] thigh and raise up the back region [of his body]. [This] is the partridge pose. kākāsanavat samsthitau jañghādvayam ${ }^{211}$ ūruni samminlya prṣthapradeśs $e^{212} \bar{u} r-$ dhvam nayet titiryāsanam bhavati || 34 ||

35. Having supported [himself] with both hands on the ground, joining both knees on the navel and supporting [in the air] the shanks and thighs, [the yogi] should remain thus. [This] is the heron pose.

hastābhyām avanim avaștabhya jānudvayam nābhau saṃmīlya jainghā[-] ūruṇ $\bar{\imath}^{213}$ samstabhya tișthet bakāsanam bhavati || 35 ||

36. Having adopted the lotus pose, [the yogi] should support [himself] with the palms of both hands on the ground, lift posteriorly both feet, [which are] fastened

210 Emend. -dvayam : Codex -dvaye.

211 Conj. Preisendanz jañghādvayam : Codex jañghā.

212 Emend. prsțthapradeśe : Codex prasțapradeśe.

213 Emend. -üruṇi : Codex -ūruni. 
in lotus pose, and remain thus. [This] is Bhāradvāja's pose.

[fol. 9r] padmāsanam saṃsthāpya hastatalābhyām dharām avaștabhya padmāsanayuktacaraṇadvayam pṛșthabhāge nītvā tișthet bhāradvājāsanam ${ }^{214}$ bhavati || 36 ||

37. Having put the palms of the hands on the ground, [the yogi] should make the soles of the feet fly upwards and [then] fall [down] to the ground. He should do thus again and again. [This] is the "flying up of the rooster" [pose]. hastatale bhūmau krtvā pādatale ${ }^{215}$ ca ùrdhvam uḍ̂̄nam krtvā bhūmau patet ittham punah punah kuryāt kukkuṭoḍānam ${ }^{216}$ bhavati || 37 ||

38. Having placed one foot on [the back of] the neck, [the yogi] should fix the second foot above it, support [the body] with the palms of both hands [on the ground] ${ }^{217}$ and remain thus. [This] is the wood-sparrow pose.

ekam pādam grīvāyām saṃsthāpya dvitīyam ${ }^{218}$ pādam upari vinyasya hastatalābhyām avaștabhya tiṣthet araṇyacațakāsanam bhavati || 38 ||

39. Having supported [himself] with the palms of both hands on the ground, fixing the elbows on the navel and holding the body [straight] like a stick, [the yogi] remains [thus. This] is the peacock pose.

hastatalābhyām avanim avaștabhya kūrparau nābhau vinyasya daṇdavac charīram dhṛtvā tiṣthet mayūrāsanam bhavati || 39 ||

40. Having positioned [himself] as in the peacock pose, [the yogi] should hold the wrist of one hand with the other. [This] is the lame peacock pose.

[fol. 9v] mayūrāsanavat ${ }^{219}$ samsthāpya ekena hastena ekasya hastasya maṇibandham dhārayet paingumayūrāsanam bhavati || 40 ||

41. Having adopted a prone, straight posture and having supported [himself] with the soles of both feet on the ground, [the yogi] should stand up. [This] is the sword pose.

nyubjạ̣ saralam āsanaṃ kṛtvā pādatalābhyām bhūmim avaștabhya uttiṣthet khadgāsanam bhavati || 41 ||

214 Emend. bhāradvājāsanam : Codex bhāsadvājāsanam.

215 Emend. Preisendanz pādatale: Codex padatale.

216 Emend. Preisendanz kukkuto- : Codex kukkutto-.

217 According to the picture of the aranyacatakāsana in the Śritattvanidhi (Sjoman 1999: pl. 15), the yogi's torso is upright and his hands on the ground. Thus, I suspect that the Sanskrit description of this pose in the Hațābhyāsapaddhati has omitted the word bhümau.

218 Emend. dvitìyam : Codex dvìtīyam.

219 Emend. mayūrāsanavat: Codex mayūrāsanat. 
42. Having supported [himself] with both elbows on the ground and the jaw with the palms of both hands, [the yogi] should raise [himself] up. ${ }^{220}$ [This] is the spear pose.

kūrparābhyām avanim avaștabhya hastatalābhyām hanum avaștabhya uttișthet śūlāsanaṃ bhavati || 42 \||

43. Having supported [himself] with the palms of both hands on the ground and lifting the toes up [into the air, the yogi] should dance on the palms of the hands. [This] is the "inverted dancing" [pose].

[fol. 10r] hastatalābhyām bhūmim avaștabhya ūrdhvam pādāgre kurvan hastatalābhyām nartanam kartavyam viparītanṛtyaṃ bhavati || 43 ||

44. In the position of inverted dancing, [the yogi] should touch the nose on the ground and take [it] up. He should touch [the ground] again [and again. This] is the hawk pose.

viparītanṛtyavat ${ }^{221}$ sthitau nāsikām ${ }^{222}$ bhūmau saṃspṛsya ūrdhvam nītvā punah samspṛśet śyenāsanam bhavati || $44 \|$

45. Having placed the [top of the] skull on the ground, [the yogi] should lift up the feet. [This] is the skull pose. ${ }^{223}$

[fol. 10v] kapālaṃ bhūmau nidhāya ūrdhvaṃ pādau nayet kapālāsanam bhavati || 45 ||

46. Having lain pronely, placing the hands on the buttocks, lengthening the legs and joining [them] together, [the yogi] should move with his chest. [This] is the snake pose.

nyubjam śayanam kṛtvā hastau nitambe samsthāpya pādau dīrghīkrtya saṃmīlayan urasā $\bar{a}^{224}$ gantavyam sarpāsanam bhavati || 46 ||

47. Having lain pronely, [the yogi] should hold the big toes with the hands, with the heels crossed at the back, and should roll [around. This is the prone pose. ${ }^{225}$ ]

220 One might understand uttisthet to mean that the yogi should stand up. However, the picture of the śülāsana in the Śrittattvanidhi (Sjoman 1999: pl. 7) clearly has the legs raised while the elbows are on the ground.

221 Emend. viparìta- : Codex viparita-.

222 Conj. nāsikām : Codex nāsikā.

223 According to the picture of the kapālāsana in the Śritattvanidhi (Sjoman 1999: pl. 6), the yogi is supporting himself with the palms on the ground, as in a three-point headstand. His arms are wide apart.

224 Emend. urasā : Codex urasāṃ.

225 The description of this pose matches the picture and description of the nyubjäsana in the Śritattvanidhi (Sjoman 1999: pl. 19 and p. 84). 
[fol. 11r] nyubjam śayanam kṛtvā prṣțhe pārṣ̣ivyutkrameṇa ${ }^{226}$ hastābhyām pādāinguṣthau dhṛtvā loḍaet || 47 ||

Now, the Stationary Poses.

atha sthānāsanāni $i^{27}$

48. Having extended the legs on the ground like a stick, [the yogi] should hold the big toes with the hands, fix the forehead on the knees and remain [thus. This is the "stretching the back" pose. ${ }^{228}$ ]

daṇdavad bhūmau caraṇau prasārya hastābhyām ànguṣthau dhṛtvā jānūpari ${ }^{229}$ lalātạ̣ vinyasya tịṭthet || 48 ||

49. Having extended one leg, pressing the perineum with the heel of the [other] foot, holding the big toes of the extended leg with both hands, [the yogi] should fix his head on the knee. [This] is the "stretching half the back" [pose].

ekam pādam prasārya ekapādasya pārṣninā sīvanīm ${ }^{230}$ sampị̂̀dya hastadvayena prasāritapādāinguștham dhṛtvā jānūpari ${ }^{231}$ mastakam nyaset ardhapaścimatānam bhavati || 49 ||

50. Having positioned [himself] as in the "stretching the back" [pose] and holding one foot on [the back of] the neck, [the yogi] should remain thus. [This] is the "stretching the upper back" [pose].

paścimatānavat saṃsthitim kṛtvā ekam pādam grīvāyām dhṛtvā tiṣthet ūrdhvapaścimatānam ${ }^{232}$ bhavati || 50 ||

51. Having grasped the toes of the feet with both hands, [the yogi] should touch the big toes, one at a time, on the ears. [This is the bow pose. ${ }^{233}$ ]

226 Emend. pārșni- : Codex pārșnī-.

227 Conj. sthānāsanāni : Codex sthānānyāsanāni.

228 The description of this pose matches the picture and description of the garbhäsana in the Śritattvanidhi (Sjoman 1999: pl. 19 and p. 84). However, it is quite probable that the name garbhäsana is a mistake in the Śritattvanidhi. The sequence of àsana-s in the Hathābhyāsapaddhati indicates that this pose is the beginning of a series most probably based on paścimatānāsana because the name paścimatāna is mentioned in the description of the next pose called ürdhvapaścimatāna. Furthermore, this pose is called paścimatānāsana or paścimottānāsana in earlier yoga texts (e.g., ŚS 3.109 and HP 1.30).

229 Emend. jānüpari: Codex jānupari.

230 Emend. sīvanìm : Codex sīvani.

231 Emend. jānūpari : Codex jānupari.

232 Emend. ürdhva- : Codex urdhva-.

233 The description of this pose matches the picture and description of the dhanurāsana in the Śritattvanidhi (Sjoman 1999: pl. 18 and p. 84). 
[fol. 11v] hastadvayena pādadvayāgre gṛhìtvā ekaikaṃ pādānguștham karnayoh spróst $\|51\|^{234}$

52. Having fixed [one] foot on the [opposite] thigh and the other foot on the other thigh, [the yogi] should hold the big toes with the hands crossed behind the back and remain thus. [This] is the bound lotus pose.

[fol. 12r] ūruni pādam vinyasya itarasmin üruṇi itaram pādam nyasya prșțibhāgena vyatyayena hastābhyām pādañgușthau dhṛtvā tișțhet baddhapadmāsanam bhavati $\|52\|$

53. Having adopted the lotus pose, [the yogi] should fix both arms inside the feet, thighs and shanks, support [himself] with the palms of both hands on the ground and remain [thus. This] is the rooster pose.

padmāsanam krtvā carana[-] ūrujanghhānām ${ }^{235}$ antare bāhudvayam nyasya hastataläbhyām bhūmim avaștabhya tișthet kukkuṭāsanaṃ bhavati || 53 ||

54. Having remained as in the rooster pose, [the yogi] should hold the wrist of one hand with the other, support [himself firmly] with the palm of the [held] hand on the ground and remain [thus. This] is the lame rooster pose.

kukkutāsanavat ${ }^{236}$ sthitvā ekena hastena anyasya hastasya manibandham dhṛtvā hastatalena bhūmim viștabhya tișthet pañgukukkuțāsanam bhavati || 54 ||

55. Having lain pronely, [the yogi] should place both heels on the neck. Having held both ankles with the hands, [the yogi] should remain [thus. This is called the libation-bowl pose. ${ }^{237}$ ]

nyubjam śayanam kṛtvā pārșnidvayam ${ }^{238}$ grīvāyām sthāpayet hastadvayena gulphadvayam dhṛtvā tișthet || 55 \|

234 The following comment, which seems unrelated to the äsana-s in this section, has been written beneath the description of the dhanurāsana on fol. 11v: dohkuttanam \| ūrukuțtanam \| pārśvakuțtanam \| ityādīni kuțțanāni mușținā bāhunā pārṣninā bhittyā bhūminā kartavyāni || Emend. Preisendanz ityādīni : Codex ityādini. "Beating of the arms, thighs, the sides and so on. [These] beatings should be done with a fist, arm, heel, wall [or] the ground."

235 Emend. -jañghānām : Codex -jaghānām.

236 Emend. kukkutāsanavat: Codex kukkuṭāsanava.

237 The name of this pose is given in the next description. However, the description of this pose matches the picture and description of the pädahastasamyogāsana in the Śrittattvanidhi (Sjoman 1999: pl. 19 and p. 84). The compound pādahastasamyogāsana appears to me to be a late improvisation, and the fact that the arghyāsana is mentioned (Sjoman 1999: 75) in the Śritattvanidhi's description of the cakrāsana but not described separately in its section on āsana practice, somewhat confirms this.

238 Emend. pārṣnidvayaṃ : Codex pārṣnīdvayam. 
56. Having remained as in the libation-bowl pose, [the yogi] should support [himself] with the palms of both hands on the ground. [This] is the parasol pose. $^{239}$

[fol. 12v] arghyāsanavat ${ }^{240}$ sthitvā hastatalābhyām bhūmim avaștabhnuyāt chatrāsanam bhavati || 56 ||

57. Having supported [himself] with both hands on the ground, placing the knees on both shoulders and the heels on the chest, [the yogi] should remain thus. [This] is the garland pose.

hastābhyām avanim avaștabhya skandhayor ${ }^{241}$ jānunī saṃsthāpya pārș̣ñ $\bar{\imath}^{242}$ urasi nidhāya tiṣthet mālāsanam bhavati || 57 ||

58. Remaining in the rooster pose and taking the thighs as far as the shoulders, [the yogi] should remain [thus. This] is the Hamsa-bird pose.

[fol. 13r] kukkuțāsanam sthitvā skandhaparyantam ūruṇ̄ nìtvā ${ }^{243}$ tișthet hamsāsanaṃ bhavati || 58 ||

59. Having placed the knees on the ground, [the yogi] should hold with the hands both arms crossed over one another and remain upright. [This] is the monkey pose.

jānunī bhūmau saṃsthāpya hastābhyām bāh $\bar{u}^{244}$ parasparam dhṛtvā saralam tișthet vānarāsanam ${ }^{245}$ bhavati || 59 \||

60. [The yogi] should wrap both shanks one over the other, place them on the ground, put the thighs and buttocks on them and remain thus. [This] is the mountain pose.

jan்ghādvayam parasparam veștayitvā bhūmau saṃsthāpya ${ }^{246}$ tadupari ūruṇī $\bar{\imath}^{247}$ nidhāya ${ }^{248}$ tadupari nitambam nidhāya tișthet parvatāsanam bhavati || 60 ||

61. Having placed the soles of the feet on the ground and the knees on the chest, [the yogi] should bind the shanks and thighs with the hands reversed and remain

239 The description of this pose matches the picture and description of the cakrāsana in the Śritattvanidhi (Sjoman 1999: pl. 6 and p. 75).

240 Emend. arghyāsanavat: Codex arghyāsanava.

241 Emend. skandhayor: Codex skandhayo.

242 Emend. pārș̣nī: Codex pārṣni.

243 Emend. ūrunī nītvā : Codex ūruni nitvā.

244 Emend. $b \bar{a} h \bar{u}:$ Codex $b \bar{a} h u$.

245 Conj. vānarāsanam : Codex vārāsanam.

246 Conj. samsthāpya: Codex saṃsthā.

247 Emend. ùrunī : Codex ūruni.

248 Emend. nidhāya: Codex nidhaya. 
thus. [This] is the noose pose.

pādatale bhūmau nidhāya jānun $\bar{\imath}^{249}$ urasi nidhāya viparītahastābhyām ūrusahitajainghe nibaddhvā ${ }^{250}$ tiṣthet pāśāsanam ${ }^{251}$ bhavati || 61 ||

62. Having supported [himself] with both heels on the ground and holding the ankles with both hands, [the yogi] should remain thus. [This] is the goose [pose]. [fol. 13v] pārṣnibhyām bhūmim avaștabhya hastadvayena gulphau dhṛtvā tișṭet kādambam bhavati || 62 ||

63. Having inserted both hands through the thighs, [the yogi] should hold the buttocks, support [himself] with the soles of both feet on the ground and remain thus. [This] is the girdle pose.

ūrumadhyāt hastau niveśya nitambạ̣ dhṛtvā pādatalābhyām bhūmim avaștabhya tișthet kāñcyāsanaṃ bhavati || 63 ||

64. Having bound the fingers of the hands, [the yogi] should make his whole body pass through the middle of the arms and remain thus. [This] is the "wringing the limbs" [pose]. ${ }^{252}$

[fol. 14r] hastayoḥ an்ulīr baddhvā hastayor madhyāt sarvam añgam niṣkāsayitvā tiṣthet angamoțanam bhavati || 64 ||

65. Having placed the soles of the feet, one at a time, in the armpits, [the yogi] should remain thus. [This] is the pillow [pose].

ekaikam pādatalam kukṣau nidhāya tiṣthet ucchīrṣakam ${ }^{253}$ bhavati || 65 ||

66. Having placed the knee on [one] side of the chest and the heel [of that leg] on the second side of the chest, [the yogi] should hold [the knee and heel] with both arms and remain thus. [This is the "union of the chest and knee" pose. ${ }^{254}$ ] jānum ${ }^{255}$ stanapradeśe nidhāya pārṣnim ${ }^{256}$ dvitīyasthānapradeśe $e^{257}$ nidhāya hastadvayena dhrtvā tișthet || 66 ||

249 Emend. jānunī: Codex jānuni.

250 Emend. nibaddhvā : Codex nabaddhvā.

251 Emend. pāśāsanam : Codex paśāsanaṃ.

252 The description of this pose matches the picture and description of the hastängulibaddhāsana in the Śritattvanidhi (Sjoman 1999: pl. 19 and p. 84).

253 Emend. ucchìrșakam : Codex ucchirșakam.

254 The description of this pose matches the picture and description of the hrjjänusamyogāsana in the Śrittattvanidhi (Sjoman 1999: pl. 19 and p. 85).

255 Emend. jānum : Codex jānu.

256 Emend. pārṣnim : Codex pārṣni.

257 Conj. dvitīya- : Codex dvitī-. 
67. Having put the soles of the feet on the palms of both hands, [the yogi] should remain thus and [then] walk around. [This] is the shoe pose. hastatalayoh pādatale krtvā tiṣthet gacchet pādukāsanam bhavati || 67 ||

68. [The yogi] should place the soles of both feet on the ground and the elbows on the insides of the [bent] knees and hold the region of the ankles with the hands. He should remain thus. [This] is the "snapping [at the heels]" pose.

[fol. 14v] pādatale bhūmau samsthāpya jānumadhye kūrparau sthāpya hastābhyām gulphapradeśe $e^{258}$ dhṛtvā tiṣthet grāhāsanam bhavati || 68 ||

69. Having placed both fists on the ground and having extended the legs [straight] like a stick, [the yogi] should remain thus. [This] is the Parpata-plant pose.

mușt $\bar{i}^{259}$ bhūmau saṃsthāpya pādau daṇdavat prasārya tiṣthet parpaṭāsanam bhavati || 69 ||

70. Having placed on the ground the fists ton the little finger side $\dagger$ and placing the soles of the feet on [them, the yogi] should move his body like a horse. [This] is the horse pose. [Likewise,] the elephant's seat is [moving the body] like an elephant and the camel's seat is [moving the body] like a camel.

[fol. 15r] mușți $\bar{i}^{260} \dagger$ †anișthikāpradeśena $\dagger$ bhūmau nidhāya upari pādatale samsthāpya aśvavat śarīram calanīyam ${ }^{261}$ aśvāsanam bhavati gajavat gajasādanaṃ uṣtravat uṣtrāsādanaṃ bhavati || 70 ||

71. Having taken the shoulders up to the head [while sitting, the yogi] should remain thus. [This] is the two-headed [pose].

skandham $^{262}$ śirahparyantam nìtvā sthātavyaṃ dviśīrṣam bhavati || 71 ||

72. Having put his jaw on his navel, [the yogi] should remain thus. [This] is the humpbacked pose.

nābhau hanum ${ }^{263}$ nidhāya tiṣthet kubjāsanam bhavati || 72 ||

73. Having placed the palms of both hands on the ground, [the yogi] should leave the ground [by lifting the body up] between the hands, make the legs [straight] like a stick and move the body around like a swing. [This] is the swing pose.

258 Emend. gulphapradeśe: Codex gulpapradeśo.

259 Emend. muṣtī : Codex muști.

260 Emend. musțī- : Codex muști-.

261 Emend. calaniyam: Codex calaniyam.

262 Emend. skandham: Codex skandhah.

263 Emend. hanum : Codex hanam. 
hastatale bhūmau nidhāya hastamadhyāt bhūmim ${ }^{264}$ santyajya $^{265}$ dandarūpau pādau krtvā preñkhavac ${ }^{266}$ [fol. 15v] charīram cālanīyam preñkhāsanam ${ }^{267}$ bhavati $\|73\|$

74. Having remained as in the swing [pose, the yogi] should take the toes over the head, place the back [of the body] on the ground and remain thus. ${ }^{268}$ preñkhavat sthitvā pādāgre mastakopari nìtvā prșthabhāgam ${ }^{269}$ bhümau nidhāya tișthet || 74 ||

Now, the Standing Poses.

[fol. 16r] atha utthānāsanāni $i^{270}$

75. Having joined together both heels [while] standing, [the yogi] should take the buttocks to the level of the knees and remain thus. [This] is the pressure pose. pārṣnidvayam $\prod^{271}$ sammmīlya sthitvā nitambam jānupradeśe ānīya ${ }^{272}$ tișthet utpị̀̂asanam ${ }^{273}$ bhavati $\| 75$ ||

76. Having placed one foot on the ground, [the yogi] should take the buttocks to the level of the knees, put the second foot on the knee and remain thus. [This] is the "flying chariot" pose.

ekạ̣ pādạ̣ bhūmau nidhāya nitambam jānupradeśe ānīya dvitīyam pādạ̣ jānuni ${ }^{274}$ nidhāya tișthet vimānāsanam ${ }^{275}$ bhavati || 76 ||

77. Having placed the soles of both feet on the ground and taking the hands [down] along the back [of the body] as far as the shanks, [this] is the pigeon's seat.

264 Emend. bhūmim : Codex bhümi.

265 Emend. santyajya: Codex tyajya.

266 Emend. prenkhavac: Codex prekhava.

267 Emend. preñkhāsanam : Codex prekhāsanam.

268 Unfortunately, the name of this pose is not recorded, and the Śritattvanidhi (Sjoman 1999: pl. 19) simply repeats the name of the former pose (i.e., prenkhāsana). One would expect something like ürdhvaprèikhāsana (cf. ürdhvapaścimatāna, no. 50).

269 Emend. prsțhabhägam : Codex prșthibhāge.

270 Emend. utthānāsanāni : Codex uttāna āsanāni.

271 Emend. pārșnidvayam : Codex pārșnidvaya.

272 Emend. ànìya: Codex aniya.

273 Emend. utpī dāsanam : Codex utpițāsanam.

274 Emend. jānuni : Codex jānunī.

275 Emend. vimānāsanaṃ : Codex vimānasanaṃ. 
pādatale bhūmau nidhāya prșthabhāgena ${ }^{276}$ hastau jañghāparyantam ${ }^{277}$ nìtvā ${ }^{278}$ kapotapit thakam ${ }^{279}$ bhavati || 77 ||

78. Having supported [himself] with one foot on the ground and with the other foot on the thigh, [the yogi] should stand and sit. It should be done thus again and again. [This] is the half-moon [pose].

ekena pādena bhūmim avaștabhya anyapādatalena ūrum ${ }^{280}$ avaștabhya tișthet $\bar{a} s t a^{281}$ iti punah punah kartavyam ardhacandram bhavati || 78 \|

79. While standing and pressing on the region of one hip ${ }^{282}$ with the heel [of the other foot, the yogi] should stand [on one leg] and raise [the other. The yogi] should do thus again and again. [This] is the spike pose.

[fol. 16v] tișthan san ${ }^{283}$ pārṣninā itarajaghanapradeśe sampīidya sthātavyam utthitavyam iti punah punaḥ kartavyam śañkvāsanam bhavati \| 79 \|

80. [The yogi] should stand on one leg and raise [the other. ${ }^{284}$ This] is [Śiva's] Tāṇ̣ava-dance pose. ekena pādena sthātavyam utthātavyam tāṇ̣̂āsanam bhavati || 80 ||

81. Having placed one foot on the [back of the] neck, [the yogi] should sit [and then] stand up [with the leg on the neck. This] is Trivikrama's pose.

[fol. 17r] grīvāyām pādam saṃsthāpya sthātavyam utthātavyam trivikramāsanam bhavati || $81 \|$

276 Emend. prșța- : Codex prșți-.

277 Emend. paryantam : Codex parayantam.

278 Emend. nītvā : Codex nitvā.

279 Conj. -pitthaka: Codex -nițaka. It is also possible that nițaka is a corruption of nätaka (i.e., "pigeon-dancer" pose).

280 Emend. ürum: Codex ūru.

281 Conj. āsta: Codex āșta.

282 The usual meaning of jaghana is "hip" or "buttock", but it can also mean the genitals (Monier-Williams 1899, s.v.). The Sanskrit description somewhat contradicts the picture of śankkvāsana in the Śritattvanidhi (Sjoman 1999: pl. 4), which depicts the yogi pressing the inner thigh with the heel of the other leg. The knee of the bent leg is in front of the body, so it could not press the buttock of the other leg in this position. Perhaps jaghanapradeśa (i.e., "the region of the hips/genitals") was believed to include the thighs.

283 Corr. Preisendanz san : Codex samn.

284 In the picture of the tândavāsana in the Srittattvanidhi (Sjoman 1999: pl. 10), the yogi appears to have his right leg slightly raised to one side, so that his heel is off the ground. 
82. Again and again, [the yogi] should stand up and sit down. [This] is the "standing up repeatedly" [pose].

punaḥ punaḥ utthātavyam āsitavyam ${ }^{285}$ utthānotthānam bhavati || 82 ||

83. At a distance of three cubits from a wall, [the yogi] should stand and having touched his chest on the wall and expanded [it,] he should touch it thus again [and again. This] is the "embracing [the wall]" pose.

hastatrayam bhittim parityajya sthātavyam bhittau hṛdayam samspṛ́sya niṣkāṣya punạ̣ samsprśset älinganāsanam ${ }^{286}$ bhavati || 83 ||

84. Hugging one knee to the chest, [the yogi] should stand. [This] is the "embracing the child" [pose].

ekam jānum ${ }^{287}$ urasi ālingya sthātavyam bālālinganam bhavati || 84 ||

85. Having held firmly the penis and scrotum between the thighs, [the yogi] should stand on the tips of the toes. [This] is the loincloth pose.

[fol. 17v] vrṣaṇasahitalingam ūrumadhye gādham dhṛtvā caraṇāgrābhyām sthātavyaṃ kaupīnāsanaṃ ${ }^{288}$ bhavati || 85 ||

86. Having clasped both hands [together], [the yogi] should jump both feet inside them, outside, and inside [again. This] is the "jumping over the threshold" [pose]. ${ }^{289}$

hastadvayam ${ }^{290}$ baddhvā ${ }^{291}$ tanmadhye $e^{292}$ caranadvayam uḍ̂̄nena bahir ānīya anta $^{293}$ nayet dehalyullanghanam bhavati || 86 ||

87. Having jumped up, [the yogi] should strike his buttocks with both heels. [This] is the deer pose.

[fol. 18r] uḍ̂ānam kṛtvā pārṣnibhyām nitambam tādayet hariṇāsanam bhavati || $87 \|$

285 Conj. utthātavyam āsitavyam : Codex utthātavya asitavyaṃ.

286 Conj. àlinganāsanam : Codex ālingāsanaṃ.

287 Emend. jänum : Codex jānu.

288 Emend. kaupinnāsanaṃ : Codex kaupināsanaṃ.

289 In the Śritattvanidhi (Sjoman 1999: pl. 19 and p. 119), this pose is called uddānāsana. If this is the original name, it may be connected with the next pose because the latter begins with "jumping up" (i. e., uḍ̂̄ānam krtvā [...]).

290 Emend. hastadvayam : Codex hastadvaye.

291 Emend. baddhvā : Codex vyadhvā.

292 Emend. tanmadhye : Codex tanmadhyā.

293 Emend. antah : Codex atah. 
88. Having stood straight, [the yogi] should take both arms up. Having jumped up again and again, he should take [them down. This] is the pestle pose.

saralam sthitvā ūrdhvam bāhū nayet vāram vāram uḍ̂̄ānam kṛtvā nayet musalāsanam bhavati || 88 ||

89. Holding with one hand the toes of one leg, which is [straight] like a stick, and placing the sole of the other foot on the ground, [the yogi] should spin around quickly. [This] is the pole star pose.

ekena hastena daṇdarūpasya ekasya pādasyāgram dhṛtvā itarapādatalam bhūmau nidhāya tvarayā bhramaṇam kartavyam dhruvāsanam bhavati || 89 ||

90. Having extended the hands [out to the sides, the yogi] should spin [them] around. [This] is the potter's disk pose.

hastau prasārya bhrāmaṇaṃ kartavyaṃ kulālacakrāsanaṃ bhavati || 90 ||

91. Having put the big toes of the feet on the ground and having raised up the arms, [the yogi] should remain thus. [This] is the camel pose.

[fol. 18v] pādāngușthābhyām ${ }^{294}$ bhūmim dhṛtvā bāhū ūrdhvīkṛtya tișthet uṣtrāsanaṃ ${ }^{295}$ bhavati || 91 ||

92. Remaining in camel pose, raising the feet from the ground and taking [them] above the head, [the yogi] should place his back on the ground. This is the "pigeon in space" [pose]. ${ }^{296}$

uștrāsane sthitvā caraṇau bhūmer utthāpya mastakopari nītvā ${ }^{297}$ prṣthapradeśena bhūmau sthāpayet ākāśakapotam bhavati || 92 ||

93. Having placed the ankle along with the little toe of one foot at the base of the [other] thigh, and having placed the knee [of the lotus leg] on the heel of the other foot, [the yogi] should remain thus and join his hands together. [This] is Garuda's pose.

294 Emend. pādāngușthābhyāṃ : Codex pādām gulpābhyāṃ.

295 Emend. uștrāsanam : Codex uștrasanam.

296 It is difficult to reconcile the description of the ustrāsana with the instructions given for the ākäśakapotāsana. One might make sense of it by supplying; "Having stood in the camel pose, [bending forward to place the palms of both hands and the back of the head on the ground,] raising the feet from the ground and taking [them] above the head, [the yogi] should place his back on the ground. This is the 'pigeon in space' [pose]." This interpretation assumes that the ākáśakapotāsana is a forward rolling movement. Unfortunately, it is not illustrated or described in the Śritattvanidhi.

297 Conj. nìtvā : Codex bhītvā. 
[fol. 19r] ūrumūle itarapādasya kaniș̣hikāpradeśena ${ }^{298}$ gulpham $^{299}$ saṃsthāpya tad eva jānum ${ }^{300}$ itarapādapārṣnyām ${ }^{301}$ saṃsthāpya tișthet hastau sammmīlayet garựāsanam ${ }^{302}$ bhavati || 93 ||

Now, the Poses with a Rope.

atha rajjvāsanāni $i^{303}$

94. Having clasped a rope [secured horizontally above the head ${ }^{304}$ ] with both hands, [the yogi] should hold both legs between the hands, above the head and [then] on the ground. He should throw [his legs up over his head in this manner] again and again. [This] is the cockroach pose.

[fol. 19v] hastadvayena rajjum dhṛtvā pādadvayam hastamadhyāt ${ }^{305}$ sirasopari bhūmau nidhāya punaḥ punaḥ saṃkṣipet paroṣnyāsanaṃ bhavati || 94 \|

95. Having supported the region of the navel on a rope, [the prone yogi should remain horizontal in the air,] rigid like a stick. [This] is the stick pose. ${ }^{306}$ nābhipradeśạ̣ rajjau dhārayitvā daṇ̂avat sthirībhavet danḍ̄sanam bhavati ${ }^{307}|| 95$ ||

96. Having placed the buttocks on a [horizontal] rope, [the supine yogi] should become rigid like a stick [horizontally in the air. This] is the weight pose. [fol. 20r] rajjau nitambam sthāpayitvā dandavat ${ }^{308}$ sthirībhavet bhārāsanam bhavati || 96 ||

97. Having held a [vertical] rope with both hands, [the yogi] should climb up [it. This] is Nārada's pose.

hastābhyām rajjum dhṛtvā ūrdhvam ārohet nāradāsanam bhavati || 97 ||

298 Conj. Preisendanz -pradeśena : Codex -pradeśa-.

299 Emend. -gulpham : Codex -gulphāṃ.

300 Emend. jānum: Codex jānu.

301 Emend. -pārșnyām : Codex -pārș̣nam.

302 Emend. garud̄āsanam : Codex gurūdāsanam.

303 Diagnostic Conj. rajjuāsanāni : Codex rajvānyāsanāni.

304 This is depicted in the Śrittattvanidhi's illustration of the paroṣnyāsana (Sjoman 1999: pl. 11) and it makes sense of the Sanskrit description.

305 Emend. madhyāt: Codex mādhyāt.

306 The name of this pose has been omitted from this description, but it matches the description and illustration of the dandāsana in the Śritattvanidhi (Sjoman 1999: pl. 11 and p. 78).

307 Diagnostic Conj. sthirībhavet daṇ̂̄āsanam bhavati : Codex sthiram bhavati.

308 Emend. dandavat: Codex dandava. 
98. Having assumed the lotus pose and having held a [vertical] rope with both hands, [the yogi] should climb [up it. This] is the "[climbing up to] heaven" pose. padmāsanam kṛtvā hastābhyām rajjum dhṛtvā ārohet svargāsanam bhavati || 98 ||

99. Having assumed the rooster pose and having held a [vertical] rope with the hands, [the inverted yogi] should climb [up it. This] is the spider pose.

kukkuțāsanam kṛtvā hastābhyām rajjum dhṛtvā ārohet ūrṇanābhyāsanam bhavati $^{309}$ || 99 ||

100. Having held a [vertical] rope with both fists and having put the soles of the feet on the [fists, the yogi] should remain thus. [This] is the parrot pose.

[fol. 20v] muștibhyām rajjum dhṛtvā tadupari pādatale sthāpayitvā tiṣthet śukāsanam bhavati || 100 ||

101. Having held a [vertical] rope with the big toes above and the hands below, [the inverted yogi] should climb up [it. This] is the caterpillar [pose].

[fol. 21r] pādāngușthābhyām ūrdhvam rajjuṃ dhṛtvā adhah rajjum hastābhyām dhṛtvā ārohet tṛnajalū $k \bar{a}^{310}$ bhavati || $101 \|$

102. Having held a [vertical] rope with one fist, [the yogi] should climb up [it. This] is the grub pose.

ekayā muștyā rajjuṃ ${ }^{311}$ dhṛtvā ārohet vṛntāsanam bhavati || 102 ||

103. Having pushed the fists through the thighs and knees, [the yogi] should hold two [vertical ropes] with them, while holding a [counter-]weight [such as a stone $^{312}$ ] with the teeth, and should climb up. [This] is the curlew pose. ūrujānvantarābhyām muṣt $\bar{i}^{313}$ niṣkāsya tābhyām rajjudvayam dhṛtvā dantaih bhāraṃ dhṛtvā ārohet krauñcāsanam ${ }^{314}$ bhavati || 103 ||

309 Diagnostic Conj. ūrṇanābhyāsanam bhavati : Codex ūrnanābhyāsana.

310 Emend. trrnajalūkā : Codex tranajalukam.

311 Emend. rajjum : Codex rañjjum.

312 This is depicted in the Srìtattvanidhi's illustration of the krauñcāsana (Sjoman 1999: pl. 12).

313 Emend. muștīi : Codex muștīịn.

314 Emend. krauñcāsanaṃ : Codex kraucāsanaṃ. 
Poses by which piercing of the sun and moon [occurs] are [now] taught. ${ }^{315}$ sūryacandrabhedanāny āsanāni ${ }^{316}$ kathyante \|

104. Having placed both elbows on the ground, [the yogi] should support [himself] with the knees on the ground, place the hands on the head and heels on the buttocks and remain thus. [This] is the boar pose.

kūrparau bhūmau sthāpayitvā jānubhyām avanim avaștabhya hastau mastake samsthāpya parṣn $\bar{i}^{317}$ nitambe samsthāpya tị̦thet vārāhāsanam bhavati || 104 \|

105. Having put the left heel on the navel [and] the other foot on the [opposite] thigh, [the yogi] should clasp the outside of the right knee with the left hand and hold the toes of the [right foot, which are] below the left knee. He should remain thus. [This] is Matsyendra's seat.

[fol. 21v] vāmapārṣnim ${ }^{318}$ nābhau itarapādam ūruṇi saṃsthāpya vāmahastena dakṣinajānum bahịpradeśena saṃveștya vāmajānunah adhah pādāgram dhṛtvā tiṣthet matsyendrapịtham bhavati || 105 ||

106. Having joined together the feet, [the yogi] should take the toes onto the pelvic floor and the heels below the penis and sit on the soles of the feet thus. [This] is the perineum pose.

pādau saṃmìlya pādāgre ādhāre ${ }^{319}$ pārṣnì lingād adhaḥ ānīya pādatalayoh ${ }^{320}$ samviśet yonyāsanam bhavati || 106 ||

107. Having placed the [upturned] sole of one foot on the [opposite] thigh and having fixed the other [foot] on the other thigh, [the yogi] should remain [sitting] upright. [This] is the "lucky mark" pose. ${ }^{321}$

[fol. 22r] ūruṇi pādatalam saṃsthāpya itara ūruṇi itaram niveśya saralaṃ ${ }^{322}$ tiṣthet svastikāsanam bhavati || 107 ||

315 I do not know why these poses have been classified as "sun" and "moon" poses. Whether one takes the sun and moon to mean prānā and apāna, the pingalā and iḍa channels, or the right and left sides of the body, such associations do not appear to characterise the following poses.

316 Emend. sūryacandrabhedanāny āsanāni : Codex sūryam candrabhedenāny āsanāni.

317 Emend. parșnī : Codex parșni.

318 Emend. vāmapārṣnim : Codex vāmapārṣni.

319 Conj. ädhäre : Codex adhare.

320 Emend. -talayoh: Codex -talayo.

321 In the Hathābhyāsapaddhati, svastikāsana is the same as the unbound version of padmāsana in other yoga texts (cf. HP 1.47-49). In the Śritattvanidhi, a picture of the unbound lotus pose has been included under the name of padmāsana (Sjoman 1999: pl. 14), but the description of it is the same as that of the bound lotus pose (baddhapadmāsana).

322 Emend. saralam : Codex sasalam. 
108. Having pressed the perineum with one heel and the penis with the heel of the other foot, [the yogi] should remain [sitting] upright. [This] is the thunderbolt pose.

ekayā pārṣ̣yā sīvanim saṃpịdya itarapādapārṣny $\bar{a}^{323}$ lingam niṣpịdya saralam tiṣthet vajrāsanam bhavati || 108 ||

109. Having placed the soles of the feet on the ground, [the yogi] should take his knees to the base of his ears. [This] is the difficult pose.

pādatalābhyām bhūmim avaștabhya jānunī karṇamūle nayet utkațāsanam bhavati || 109 ||

110. Having placed both heels on the navel, [the yogi] should join the outer region of both shanks. [This] is the conch shell pose.

[fol. 22v] pārṣṇi ${ }^{324}$ nābhau samsthāpya jainghā bahihpradeśena sammīlayet śuktyāsanam ${ }^{325}$ bhavati || 110 ||

111. [The yogi] should remain like a corpse on the ground. [This] is the corpse pose.

śavavad bhūmau tiṣthet śavāsanaṃ bhavati || 111 ||

112. Having stretched out both legs, [this] is the "stretching out [the legs]" pose. pādadvayam vitanyottānāsanam ${ }^{326}$ bhavati $\| 112$ ||

\section{Appendix 3: A Comparison of Medieval and Modern Āsana-s}

The following table outlines a comparison between the shapes of the assana-s of Pattabhi Jois' Aṣtāngavinyāsa (PJAV) and those of medieval yoga texts. PJAV is only a small sample of the äsana-s taught in all modern Indian yoga schools. However, it provides a more representative sample of the àsana-s taught by Kṛ̣namamācārya and his students, whose yoga has been widely disseminated throughout the world.

When considering the results of this comparison, one should bear in mind the difficulties of comparing modern and medieval āsana-s, which I have mentioned in the conclusion of this chapter. These results neither prove nor disprove the direct influence of medieval texts on modern yoga traditions, but they suggest the

323 Conj. itarapādapārșnyā : Codex itarapādārghyā.

324 Conj. pārṣnī : Codex pārṣni.

325 Conj. śuktyāsanam : Codex śukyāsanam.

326 Conj. vitanyottānāsanam : Codex vitanottānāsanaṃ. 
types of āsana-s which modern traditions have most probably adapted from premodern Hatha Yoga. The number in round brackets indicates the number of $\bar{a}$ sana-s in a category such as standing poses. The names of the types of àsana-s (i.e., "standing", "floor" and "finishing") do not appear in Pattabhi Jois' book Yoga Mala but are generally used among practitioners: "standing" poses for those in which the body weight is supported by the legs, "floor poses" for those done close to the floor, and "finishing poses" for those which form a concluding sequence at the end of the practice. I have not counted separately variations in some of PJAV's āsana-s (e.g., jānuśîrșāsana A, B, C, D, etc.) and have not included the names of PJAV's āsana-s which did not yield a correspondence. There are further correspondences between the assana-s in the above textual sources and those in the intermediate and advanced sequences of Pattabhi Jois' Aș̣āngavinyāsa. 


\begin{tabular}{|c|c|c|c|c|c|c|c|c|c|c|c|c|}
\hline 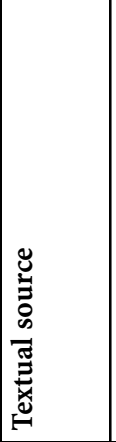 & 0 & $\begin{array}{l}\hat{\jmath} \\
\text { ì } \\
\mathcal{S}\end{array}$ & 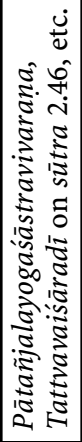 & 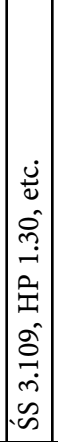 & 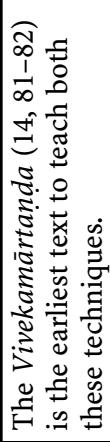 & 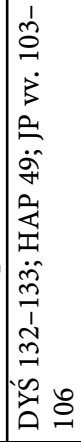 & 云 & $\begin{array}{l} \\
\text { in } \\
\text { 定 } \\
\text { 诖 }\end{array}$ & 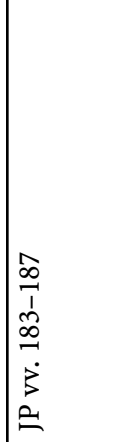 & 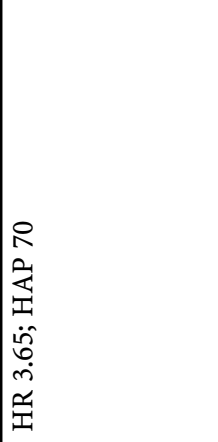 & 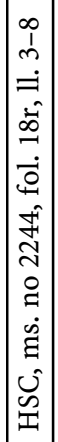 & 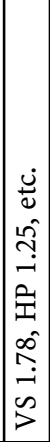 \\
\hline 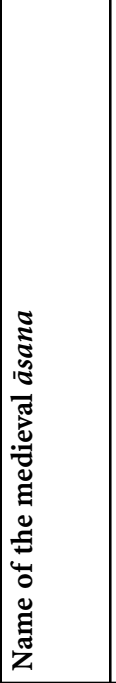 & 0 & 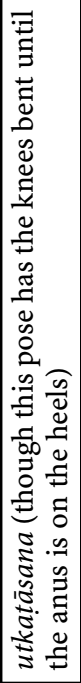 & 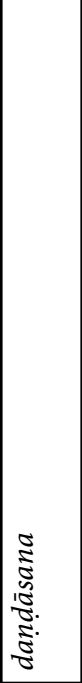 & 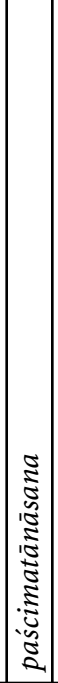 & 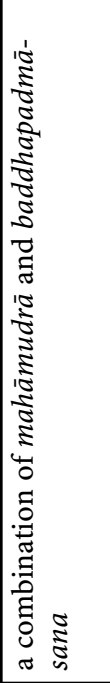 & 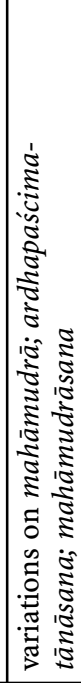 & 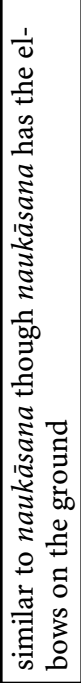 & 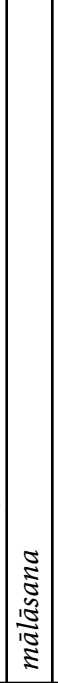 & 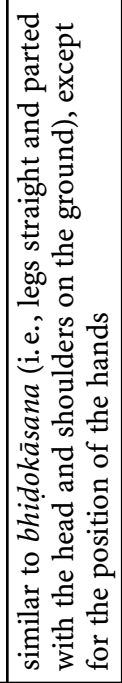 & 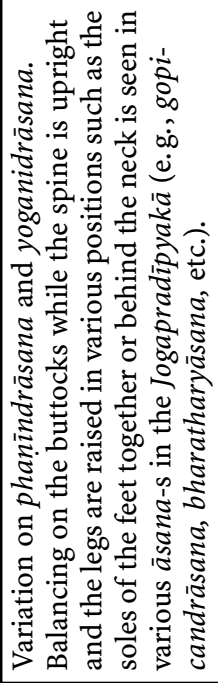 & 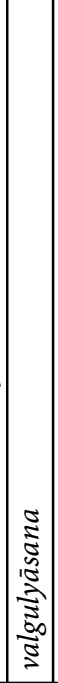 & 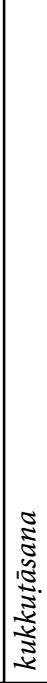 \\
\hline 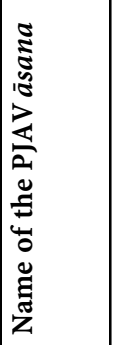 & & 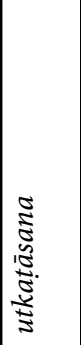 & 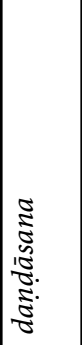 & 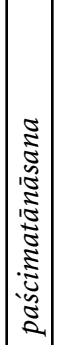 & 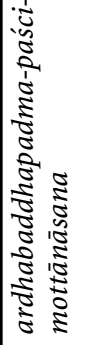 & 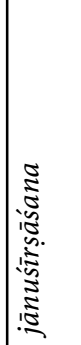 & 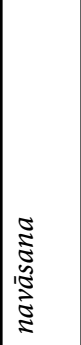 & 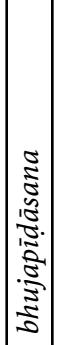 & 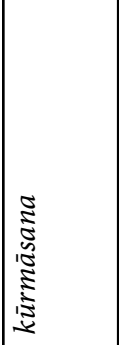 & 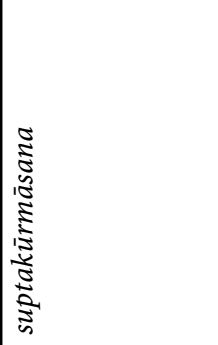 & 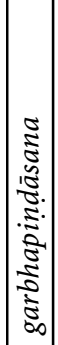 & 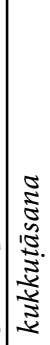 \\
\hline 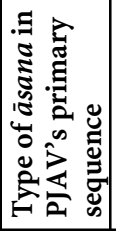 & 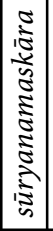 & 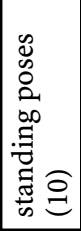 & 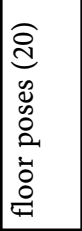 & & & & & & & & & \\
\hline
\end{tabular}




\begin{tabular}{|c|c|c|c|c|c|c|c|c|c|c|c|c|c|}
\hline 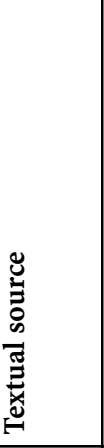 & 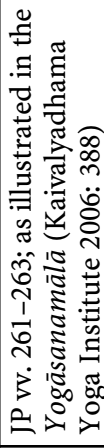 & 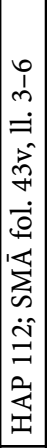 & 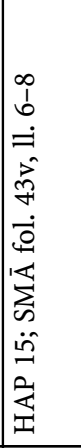 & 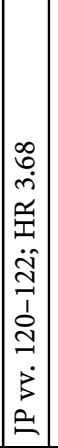 & \begin{tabular}{l}
0 \\
\hdashline \\
2 \\
2
\end{tabular} & 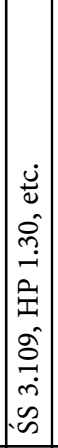 & 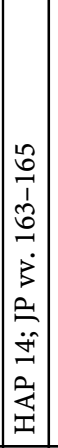 & 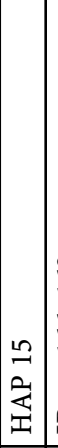 & $\begin{array}{l}8 \\
0 \\
1 \\
0 \\
0 \\
0 \\
3 \\
0 \\
0\end{array}$ & 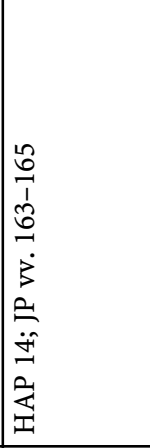 & 总 & 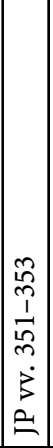 & 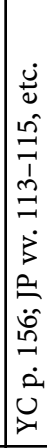 \\
\hline 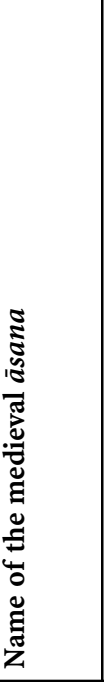 & 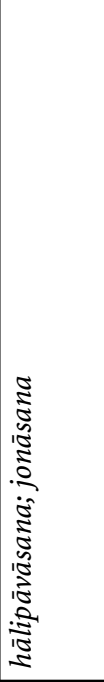 & 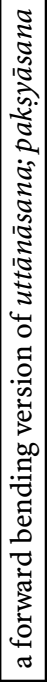 & 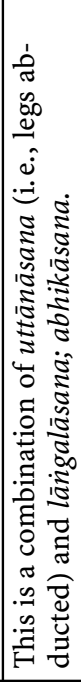 & 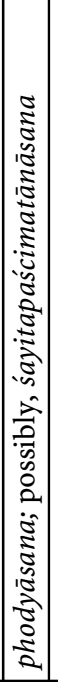 & 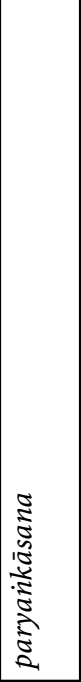 & 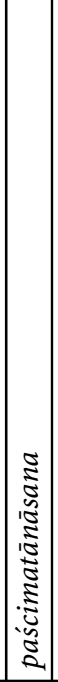 & 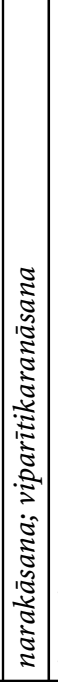 & . & 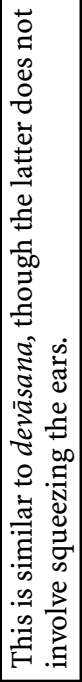 & 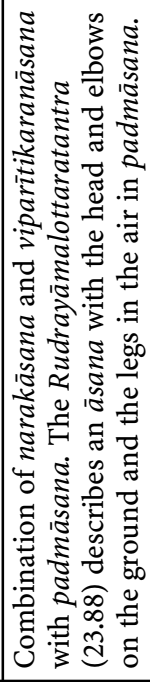 & 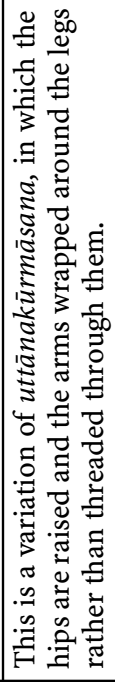 & 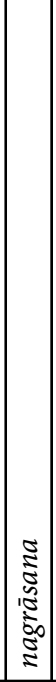 & 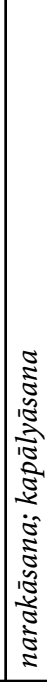 \\
\hline 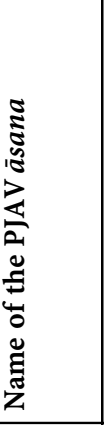 & 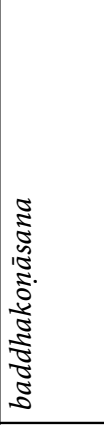 & 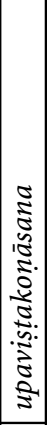 & 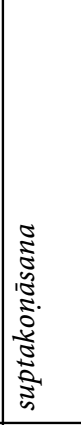 & 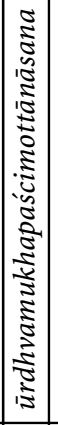 & 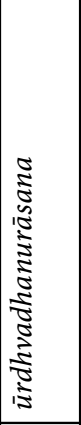 & 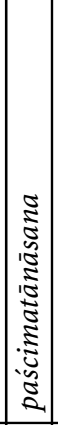 & 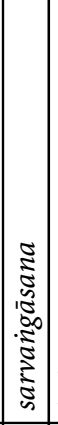 & 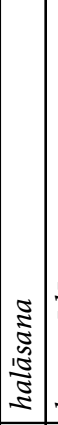 & 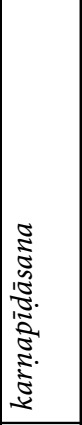 & 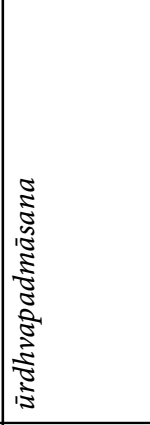 & 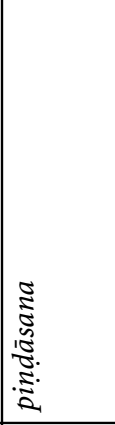 & 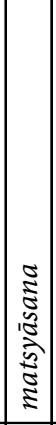 & 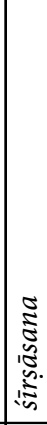 \\
\hline 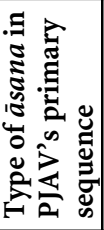 & & & & & 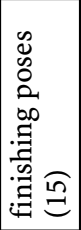 & & & & & & & & \\
\hline
\end{tabular}




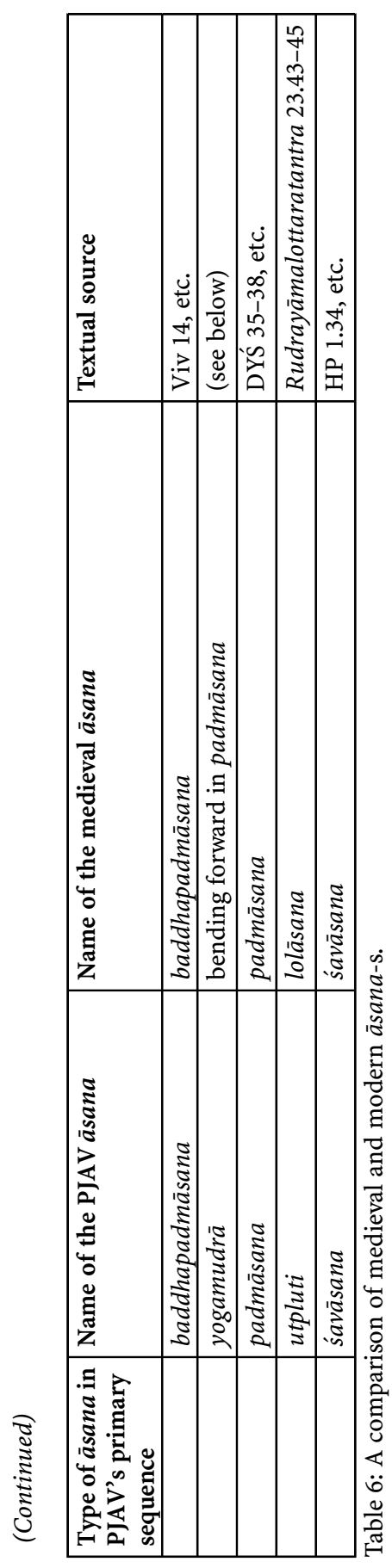




\section{Abbreviations (Primary Sources)}

DYŚ. Dattātreyayogaśāstra.

GS. Gheraṇdasaminitā.

Gś. Gorakṣaśataka, ed. Fausta Nowotny. Köln: K. A. Nowotny, 1976.

Gśk. Gorakṣaśataka, ed. Swāmī Kuvalayānanda and S. A. Shukla. Lonavla: Kaivalyadhama S. M. Y. M. Samiti, 2006.

HAP. Hațāobyāsapaddhati.

HP. Hathapradīpikā.

HR. Hatharatnāvalī.

HSC. Hathasañketacandrikā.

JP. Jogapradīpyakā.

SMĀ. Hathapradīpikā-Siddhāntamuktāvalī.

ŚS. Ś Sivasaṃhitā.

ŚTN. Śritattvanidhi.

Viv. Vivekamārtanda.

VivB. Vivekamārtanda, ms. no. 4110, Central Library, Baroda. ${ }^{327}$

VivN1. Vivekamārtanda, ms. no. C0060-03 (NS 919), National Archives of Kathmandu.

VivN2. Vivekamārtanda, ms. no. G0058-15 (NS 858), National Archives of Kathmandu.

VS. Vasișthasaṃhitā.

YC. Yogacintāmaṇi (of Śivānandasarasvatī).

YTĀ. Yogatārāvalì.

YY. Yogayājñavalkya.

\section{Other Abbreviations and Special Signs}

\begin{tabular}{|c|c|}
\hline$[-]$ & Connects two words in a compound \\
\hline$\sum$ & All collated manuscripts except those listed after it \\
\hline †yogah† & $\begin{array}{l}\text { The reading yogah is spurious and the present editor has not been able } \\
\text { to improve upon it. }\end{array}$ \\
\hline ama+ska & One akșara between "ma" and "ska" is illegible or missing \\
\hline ca] & "ca" is the lemma (i. e., the word accepted in the edited text) \\
\hline Conj. & A conjecture by the author \\
\hline Conj. [Devadatta] & A conjecture by Devadatta \\
\hline Corr. & A correction \\
\hline Diagnostic Conj. & A diagnostic conjecture by the author \\
\hline $\begin{array}{l}\text { Diagnostic Conj. } \\
\text { [Devadatta] }\end{array}$ & A diagnostic conjecture by Devadatta \\
\hline ed. & editor \\
\hline Emend. & An emendation \\
\hline & folio \\
\hline ols. & folios \\
\hline
\end{tabular}

327 I wish to thank James Mallinson for providing me with a copy of this manuscript. 


$\begin{array}{ll}\text { l. } & \text { line } \\ \text { ll. } & \text { lines } \\ \text { n. } & \text { note } \\ \text { ms. no. } & \text { manuscript number } \\ \text { r } & \text { recto } \\ \text { v } & \text { verso } \\ \text { v. } & \text { verse } \\ \text { Viv } & \text { The Gorakhnāth Mandir's edition of the Vivekamārtañạa } \\ \text { vol. } & \text { volume } \\ \text { vv. } & \text { verses } \\ \text { [word] } & \text { Square brackets enclose a word supplied in the translation. }\end{array}$

\section{References}

\section{Primary Sources}

Amanaska

see Birch 2013a.

Amaraughaprabodha

see Mallik 1954.

Amrtasiddhi

Amrtasiddhi, ms. no. H233-06. Kathmandu National Archives.

Amśumatitantra

Aṃśumadāgama, French Institute of Pondicherry transcript T0004, pp. 624-629. Available at muktabodha.org. Some chapters have been typed up as an etext by researchers at the École française d'Extrême-Orient.

Dattātreyayogaśāstra

Unpublished edition by J. Mallinson (with the help of Alexis Sanderson, Jason Birch and Péter Szántó), forthc.

Gheraṇdasaṃhitā

see Mallinson 2004.

Gorakșaśataka

Gorakșaśataka, ms. no. R7874, Government Oriental Manuscripts Library, Madras University.

\section{Hațābhyāsapaddhati}

Āsanayoga, ms. no. 46/440, Bhārat Itihās Samśodhak Maṇḍal, Pune.

Hathapradīpikā

The Hațhapradīpikā of Svātmārāma, ed. Swami Digambaraji \& Pt. Raghunatha Shastri Kokaje. Lonavla: Kaivalyadhama S. M. Y. M. Samiti, 1998.

Hațapradīpikā-Siddhāntamuktāvalī

Hațayogapradīpikā, ms. no. 6756, Rajasthan Oriental Research Institute, Jodhpur.

Hațharatnāvalī

Hațaratnāvalī of Śrīnivāsayogī, ed. M. L. Gharote et al. Lonavla: Lonavla Yoga Institute, 2009. 


\section{Hathasañketacandrikā}

(a) Hathasainketacandrikā of Sundaradeva, ms. no. R3239 (transcript), Government Oriental Manuscripts Library, Madras University.

(b) Hathasanketacandrikā of Sundaradeva, ms. no. 2244, Man Singh Pustak Prakash Library, Jodhpur.

Hathatattvakaumudi

Hațhatattvakaumudī: A Treatise on Hațhayoga by Sundaradeva, ed. M. L. Gharote et al. Lonavla: Lonavla Yoga Institute, 2007.

Jogapradīpyak̄̄

see Kaivalyadhama Yoga Institute 2006.

Jyotsnā

see Kaivalyadhama Yoga Institute 2002.

Khecarīvidyā

see Mallinson 2007a.

Pātañjalayogaśāstra

Vācaspatimiśraviracitațīkāsaṃvalitavyāsabhāṣyasametāni pātañjalayogasūtrāṇi: tathā bhojadevaviracitarājamārtaṇ̂ābhidhavrttisametāni pātañjaliyogasūtrāni. sūtrapāthasūtravarnānukramasūcībhyām ca sanāthīkṛtāni, ed. Kāsiñātha Śāstrī Āgāśe. Ānandāśramasamskrtagranthāvalih 47. Pune: Ānandāśramamudranālaya, 1904.

Rudrayāmalottaratantra

Rudrayāmalam (Uttaratantram), ed. Rāmakumāra Rāya. Varanasi: Kṛ̣nadāsa Akādamī, 2002.

Śärngarapaddhati

The Paddhati of Sarngadhara: A Sanskrit Anthology, ed. P. Peterson. Bombay Sanskrit Series 37. Bombay: Government Central Book Depot, 1888.

Śivasamhitā

see Mallinson 2007b.

Śrìtattvanidhi

see Sjoman 1999.

Tattvavaiśáradī

see Pātañjalayogaśāstra.

Vasișthasamhitā

see Kaivalyadhama Yoga Institute 2005.

Vivekamärtanda

Vivekamārtaṇda (Praṇetā Śivagorakṣa Mahāyogī Gorakṣanātha), ed. Rāmlāl Śrīvāstav. Gorakhpur: Gorakhnāth Mandir, 1983.

Vyavahāramālā

Vyavahāramālā (nāma dharmaśāstragranthah), ed. V. Veñkațarāmaśarma. Ānandāśramasaṃkṛtagranthāvalị̣ 121. Pune: Ānandāśramamudraṇālaya, 1979.

Yogabīja

Yogabīja of Gorakhanātha, ed. Rāmalāla Śrīvāstava. Gorakhapur: Gorakhnāth Mandir, 1982. 


\section{Yogacintāmaṇi}

(a) ed. Haridās Śarma. Calcutta: Calcutta Oriental Press (no date of publication). ${ }^{328}$ (b) unpublished ms. no. 3537, Scindia Oriental Institute, Ujjain. Catalogue of Manuscripts preserved in the Oriental Manuscripts Library Ujjain. Part 2 (collected from April 1935 to the end of May 1937). Gwalior: Alijar Darbar Press, 1941, p. 54.

(c) unpublished ms. no. 9784, Kaivalyadhama Yoga Institute Library, Lonavla.

(d) unpublished ms. no. 9785 (based on R635), Kaivalyadhama Yoga Institute Library, Lonavla.

(e) unpublished ms. no. 1-1337 (reel No. B39/5), National Archives Kathmandu.

(f) unpublished ms. no. M. a. I. 312, Universitätsbibliothek Tübingen.

Yogāsanamālā

see Kaivalyadhama Yoga Institute 2006.

Yogasūtra see Pātañjalayogaśāstra.

Yogatārāvalī

Śrīmacchañkarābhagavatpādaviracitā Yogatārāvalī, ed. Swāmī Śrīdayānanda Śāstrī. Varanasi: Vārāṇaseya Saṃskṛta Saṃsthāna, 1982.

Yogayājñavalkya Yoga-Yājñavalkyam: A Treatise on Yoga as Taught by Yogī Yājñavalkya, ed. P. C. Divanji. B. B. R. A. Society Monograph 3. Bombay: B. B. R. A. Society, 1954.

Yuktabhavadeva Yuktabhavadeva of Bhavadeva Miśra, ed. M. L. Gharote \& V. K. Jha. Lonavla: Lonavla Yoga Institute, 2002.

\section{Secondary Sources}

Alter, J. (2004). Yoga in Modern India: The Body between Science and Philosophy. Princeton, NJ: Princeton University Press.

Bernard, T. (1958). Hatha Yoga: The Report of a Personal Experience. London: Rider.

Birch, J. (2011). The Meaning of hatha in Early Hathayoga. Journal of the American Oriental Society, 131(4), 527-554.

Birch, J. (2013a). The Amanaska: King of All Yogas. A Critical Edition and Annotated Translation with a Monographic Introduction. Unpublished Doctoral Thesis. University of Oxford.

Birch, J. (2013b). Rājayoga: The Reincarnations of the King of all Yogas. International Journal of Hindu Studies, 17(3), 401-444.

Bouy, C. (1994). Les Nātha-Yogin et les Upanișads: étude d'histoire de la littérature hindoue. Publications de l'Institut de Civilisation Indienne 62. Paris: Diffusion de Boccard.

Bühnemann, G. (2007a). Eighty-Four Āsanas in Yoga: A Survey of Traditions (with Illustrations). New Delhi: D. K. Printworld.

328 Citations which give page numbers of the Yogacintämani are from this edition, unless otherwise stated. 
Bühnemann, G. (2007b). The Identification of an Illustrated Haṭhayoga Manuscript and Its Significance for Traditions of 84 Āsanas in Yoga. Asian Medicine, Tradition and Modernity, 3(1), 156-176.

Clark, M. (2006). The Daśanāmī-Samnyāsīs: The Integration of Ascetic Lineages into an Order. Leiden: Brill.

Dasgupta, S. (1969). Obscure Religious Cults. 3rd ed. Calcutta: Firma K. L. Mukhopadhyay.

De Michelis, E. (2004). A History of Modern Yoga: Patañjali and Western Esotericism. London: Continuum.

Ernst, C. (2003). The Islamization of Yoga in the Amrtakunda Translations. Journal of the Royal Asiatic Society, Series 3, 13(2), 199-226.

Gharote, M. L. (2009). See Hațharatnāvalī

Gharote, M. L. et al. (2006). Encyclopedia of Traditional Asanas. Lonavla: Lonavla Yoga Institute.

Gode, P. K. (1953). Studies in Indian Literary History. Vol. 1. Bombay: Singhi Jain Sāstra Śikshāpīth Bhāratīya Vidyā Bhavan.

Iyengar, G. (1998). Yoga: A Gem for Women. New Delhi: Allied Publishers.

Iyer, L. K. A. \& Nanjundayya, H. V. (1935). The Mysore Tribes and Castes. Vol. 2. Mysore: Mysore University.

Jois, P. (2002). Yoga Mala: The Seminal Treatise and Guide from the Living Master of Ashtanga Yoga. New York: North Point Press, a division of Farrar, Straus and Giroux.

Kaivalyadhama Yoga Institute (2002). Brahmānandakrtā Haṭhapradīpikā Jyotsnāa, ed. Maheśānand et al. Lonavla: Kaivalyadhama S. M. Y. M. Samiti.

Kaivalyadhama Yoga Institute (2005). Vasiștha Saṃhitā (Yoga Kānda), ed. PhilosophicoLiterary Research Department. Revised ed. Lonavla: The Kaivalyadhama S. M. Y. M. Samiti.

Kaivalyadhama Yoga Institute (2006). Jogapradīpyakā of Jayatarāma, ed. Maheśānanda et. al. Lonavla: Kaivalyadhama S. M. Y. M. Samiti.

Larson, G. (2008). Introduction to the Philosophy of Yoga. In G. J. Larson \& R. S. Bhattacharya (Eds.), Yoga: India's Philosophy of Meditation (pp. 21-159). Encyclopedia of Indian Philosophies 12. Delhi: Motilal Banarsidass.

Leach, L. (1995). Mughal and other Indian Paintings from the Chester Beatty Library. Vol. 2. London: Scorpion Cavendish.

Mallik, K. (Ed.). (1954). Siddhasiddhāntapaddhati and Other Works of Nath Yogis. Pune: Poona Oriental Book House.

Mallinson, J. (2004). The Gheranda Samhitā: The Original Sanskrit and an English Translation. Woodstock: YogaVidya.com.

Mallinson, J. (2007a). The Khecarīvidyā of Ādinātha: A Critical Edition and Annotated Translation of an Early Text of Hathayoga. Routledge Studies in Tantric Traditions. London: Routledge.

Mallinson, J. (2007b). The Śiva Saṃhitā: A Critical Edition and an English Translation. Woodstock: YogaVidya.com.

Mallinson, J. (2011). Hatha Yoga. In K. A. Jacobsen (Ed.), Brill's Encyclopedia of Hinduism. Vol. 3 (p. 770-781). Leiden: Brill.

Mallinson, J. (2013). Dattātreya's Discourse on Yoga (a translation of the Dattātreyayogaśāstra circulated to those who supported the kickstarter campaign for "Roots of Yoga"). 
Mallinson, J. (2014). Hathayoga's Philosophy: A Fortuitous Union of Non-Dualities. Journal of Indian Philosophy, 42(1), 225-247.

Mohan, A. G. (2010). Krishnamacharya: His Life and Teachings. Boston: Shambhala Publications.

Monier-Williams, M. (1899). A Sanskrit-English Dictionary: Etymologically and Philologically Arranged with Special Reference to Cognate Indo-European Languages by Sir Monier Monier-Williams M.A., K.C.I.E. New Edition, Greatly Enlarged and Improved with the Collaboration of Professor E. Leumann, Ph.D., Professor C. Cappeller, Ph.D. and other Scholars. Oxford: Clarendon Press (repr. 1970).

O'Hanlon, P. (2007). Military Sports and the History of the Martial Body in India. Journal of the Economic and Social History of the Orient, 50(4), 490-523.

Pollock, S. (1985). The Theory of Practice and the Practice of Theory in Indian Intellectual History. Journal of the American Oriental Society, 105(3), 499-519.

Reddy, V. (1982). Hatharatnavali of Srinivasabhatta Mahayogindra. With an Elaborate Introduction, Selected Text, English Translation, Critical Notes, Appendix and Word Index. Sri Medapati Subireddy Memorial Yoga Series 1. Arthamuru, E. G. Dt.: Sri M. Ramakrishna Reddy.

Sanderson, A. (2004). The Śaiva Religion Among the Khmers. Part I. Bulletin de l'Ecole Française d'Extrême-Orient, 90-91, 349-462.

Sastri, P. P. S. (1931). Descriptive Catalogue of the Sanskrit Manuscripts in the Tanjore Mahārāja Serfoji’s Sarasvatī Mahāl Library, Tanjore. Vol. 11. Srirangam: Sri Vani Vilas Press.

Satyananda, S. (1996). Asana Pranayama Mudra Bandha. Bihar: Yoga Publications Trust.

Singleton, M. (2010). Yoga Body: The Origins of Modern Posture Practice. Oxford: Oxford University Press.

Sinh Jee, HH Sir Bhagvat (1896). A Short History of Aryan Medical Science. London: Macmillan.

Sircar, D. C. (1971). Studies in the Geography of Ancient and Medieval India. Delhi: Motilal Banarsidass.

Sivananda, S. (1993). Yoga Asanas. Sivanandanagar: The Divine Life Society.

Sjoman, N. E. (1999). The Yoga Tradition of the Mysore Palace. New Delhi: Shakti Malik Abhinav Publications.

Śrīkṛṣnadāsa K. (1884). Śrītattvanidhigrantha. Mumbai: Śrīveñkațeśvara Steam Press.

Taylor, M. (2007). Perfumed by Golden Lotuses: Literary Place and Textual Authority in the Brahma- and Bhāgavatapurānas. Acta Orientalia Vilnensia, 8(1), 69-81.

Upadhyaya S. C. (1965). Rati Rahasya of Pandit Kokkoka. Bombay: Leaders Press.

White, D. (1996) The Alchemical Body: Siddha Traditions in Medieval India. Chicago: University of Chicago Press.

Yogeshwaranand S. (2001). First Steps to Higher Yoga: An Exposition of First Five Constituents of Yoga. New Delhi: Yoga Niketan Trust. 